\author{
UNITED STATES \\ DEPARTMENT OF THE INTERIOR \\ GEOLOGICAL SURVEY
}

REGIONAL APPRAISAL OF THE WILCOX GROUP IN TEXAS

FOR SUBSURFACE STORAGE OF FLUID WASTES:

PART I - GEOLOGY

By P. H. Jones, P. R. Stevens, J. B. Wesselman, and R. H. Wallace, Jr.

Open-File Report 76-394

The stratigraphic nomenclature used in this report was determined from several sources and may not necessarily follow the usage of the U.S. Geological Survey.

Bay St. Louis, Mississippi

July 1976 


\section{CONTENTS}

Page

Abstract-- 1

Introduction -

Purpose and scope-1 6

Information and concepts- 8

Acknowledgments - 9

Geology- 10

Principal features-- 10

Stratigraphy-- 21

Midway Group - 22

Wilcox Group - 22

Study methods- 24

Sedimentation-- 25

Mapping techniques-_- 30

Lower Wilcox-1- 38

Mount Pleasant Fluvial System-- 41

Rockdale Delta System-_- 44

Pendleton Bay-Lagoon System--_-_-- 61

San Marcos Strandplain-Bay System-------- 62

Cotulla Barrier-Bar System--_- 64

Indio Bay-Lagoon System-- 66

South Texas Shelf System-1- 66 
Geology--Continued

Stratigraphy--Continued

Wilcox Group--Continued

Middle Wilcox- 68

Upper Wilcox- 72

Claiborne Group 79

Structure-1- 81

Hydrothermal tectonism - 82

Conclusions- 101

References cited-102 


\section{ILLUSTRATIONS}

Plate 1. Map showing principal depositional systems and their component facies in the lower Wilcox of Texas, cumulative thickness of sand beds, and locations of geologic sections .

2. Geologic dip section $A-A^{\prime}$, from Zavala County to Duval County Tex., showing sedimentary systems and their component facies in the Wilcox Group.

3. Geologic dip section B-B', from Guadalupe County to Victoria County, Tex., showing sedimentary systems and their component facies in the Wilcox Group.

4. Geologic dip section C-C', from Milam County to Harris County, Tex., showing sedimentary systems and their component facies in the Wilcox Group.

5. Geologic dip section D-D', from Camp County to Hardin County, Tex., showing sedimentary systems and their component facies in the Wilcox Group.

6. Geologic strike section E-E', from Webb County to Newton County, Tex., showing sedimentary systems and their component facies in the Wilcox Group.

7. Map showing regional depositional system and its component facies in the upper Wilcox in Texas, the cumulative thickness of sand beds, and the locations of geologic sections.

8. Map showing altitude of the top of the Wilcox Group in Texas, locations of known salt domes, Eocene growth-fault trend, and locations of the geologic sections. 


\section{ILLUSTRATIONS}

Page

Figure 1. Map showing study area- 7

2. Diagrammatic profile showing stages in the development of the Gulf Coast geosyncline

3. Map showing thickness of Cenozoic deposits in the Gulf Coast geosyncline-..-

4. Diagrammatic dip section across Texas

Coastal Plain between the salt basins, showing growth-fault systems and their relation to the geopressured zone

5. Map showing northern Gulf of Mexico basin and adjacent areas-

6. Map showing northern Gulf of Mexico basin and adjacent area, with major structural features

7. Graph showing relation of erosion, transport, and deposition of particles of uniform size to the velocity of moving water--.-.--

8. Diagrams showing characteristic shapes of spontaneous-potential curves for sand bodies deposited under different environmental conditions - 
Figure 9. Diagram showing representative electric $\log$ patterns in each of the major depositional systems of the lower Wilcox in Texas

10. Diagram showing idealized sand-dispersal patterns in each of the principal depositional systems of the Wilcox Group in Texas

11. Diagrammatic longitudinal profile through the Mount Pleasant Fluvial System and the Rockdale Delta System, showing the relationships of principal component facies -

12. Map showing seven principal depositional systems of the lower Wilcox in Texas 39

13. Map showing project area with location of well control used in mapping depositional systems of the Wilcox Group in Texas, and cumulative thickness of sand beds in the lower Wilcox 40

14. Map showing distribution of sediment facies in the Mount Pleasant Fluvial System in Texas-- 
Figure 15. Map showing principal deltas of the

Rockdale Delta System and their

growth patterns--

16. Diagram showing principal facies and

sand pattern, high-constructive lobate

delta systems, Gulf Coast basin-_.

17. Map showing regional setting of the Yoakum

Channel

18. Diagram showing principal facies and sand

pattern, high-destructive delta systems,

Gulf Coast basin-_-

19. Diagram showing representative electric log

patterns, high-destructive delta sys-

tems, Gulf Coast basin-

20. Map showing principal sand trends in the upper Wilcox in Texas

21. Graph of fluid-redistribution model, Gulf

Coast area--

22. Seismic profile with well locations

showing fluid pressure/overburden

ratio at total depth adjacent to fault

plane-- 
Figure 23. Diagrammatic dip section showing relation

of isogeothermal surfaces, top of the geopressured zone, and structural features along line $A-A$

24. Diagrammatic dip section showing relation of 1sogeothermal surfaces, top of the geopressured zone, and structural features along line $B-B^{\prime}$

25. Diagrammatic dip section showing relation of isogeothermal surfaces, top of the geopressured zone, and structural features along line $\mathrm{C}-\mathrm{C}^{\prime}$

26. Diagrammatic dip section showing relation of isogeothermal surfaces, top of the geopressured zone, and structural features along line D-D'- 
I

I

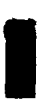

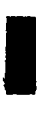

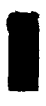

I

I

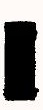

) 


\section{CONVERSION FACTORS}

The conversion factors for the terms used in this report are listed below. The metric equivalents are shown only to the number of significant figures consistent with the values for the English units within the text.

\section{$\underline{\text { English }}$}

feet (ft)

miles (mi)

feet per mile (ft/mi)

square miles $\left(\mathrm{mi}^{2}\right)$
Multiply by

0.3048

1.609

0.1894

2.590
Metric

metres (m)

kilometres $(\mathrm{km})$

metres per kilometre $(\mathrm{m} / \mathrm{km})$

square kilometres $\left(\mathrm{km}^{2}\right)$ 


\title{
REGIONAL APPRAISAL OF THE WILCOX GROUP IN TEXAS FOR SUBSURFACE STORAGE OF FLUID WASTES: \\ PART I - GEOLOGY
}

By P. H. Jones, P. R. Stevens, J. B. Wesselman, and R. H. Wallace, Jr.

\begin{abstract}
Sandy beds of the Wilcox Group in Texas are underlain and overlain by clays of the Midway and Claiborne Groups. The Wilcox is divided by a persistent shale wedge. Contrasting delta systems described as high-constructive and high-destructive exist in the divisions. "Mrged high constructive deltas characterize the lower, while the upper Wilcox was deposited as a high destructive system. Maximum sand development occurs downdip parallel to regional depositional strike in the delta facies. Further downdip, shales replace sands, and sediments are (abnormally high pressured) geopressured.

The structure of the updip portion is that of a stable shelf. Downdip, greatly thickened beds are cut by large faults. These faults and the resultant deposits are recognized as being the result of a previously unnamed phenomenon--here termed hydrothermal tectonism. This process is keyed to thermal diagenesis of the clay mineral montmorillonite and resultant transfer of overburden pressure from the rock framework to the contained fluid.
\end{abstract}


The presence of the geopressured sediments downdip and presence of fresh water updip limits the potential use of the in-between Wilcox beds for use as a toxic waste disposal unit.

\section{INTRODUCTION}

Unwanted by-products of our urban, industrialized soclety increase in volume, variety, and potential harmfulness as our population and material wealth grow. There is a general awareness of a need for effective and well-managed disposal of municipal and industrial wastes and awareness of damage that results from unwise or ill-advised disposal practices.

Each of the major classes of waste produced requires its own special management guidelines and disposal restrictions. Management requirements are already well documented for municipal wastes by sanitary engineers, for nuclear wastes by health physicists, and for oil field and petrochemical wastes by many investigators in industry and government. Solid wastes are packaged or buried, and liquid wastes are disposed into streams or to the ground through seepage ponds or wells. Waste gases are usually vented to the atmosphere; if combustible, they are burned. In general, however, little is known of the fate of a specific waste after discharge to the air, a water body, or the ground. In the past, the common criterion for successful waste management has been that deleterious effects of discharge have not been observed.

Disposal of toxic fluid wastes through wells to natural underground reservoirs (aquifers) is a long established and widely accepted practice. Although it involves a trade-off of space occupancy, this is seldom recognized. Naturally occurring fluid--generally saline ground water--is displaced 
by waste fluid from the vicinity of the disposal well. From some hydraulicallyinterconnected aquifer at the earth's surface, a volume of water roughly equal to that injected will be discharged or such a volume of potential recharge will be rejected. Disposal systems at depths of a few thousand feet (metres) may distribute these effects over broad areas, and they may not be immediately measurable; consequently, prospective discharge is generally ignored.

Aquifer systems utilized for storage of fluld wastes are usually beds of sand or sandstone interlayered with beds of clay or shale, however, some are limestone aquifers interbedded with shale.

Aquifers used for storage of toxic wastes should lie horizontally or dip gently and be areally continuous for miles. These aquifers should not contan fresh water or water undor abnormally high pressure. Permeabllity and porosity should be reasonably high and uniformly distributed. Mineral composition of the aquifer materials should be relatively simple and uniform throughout the zone that is to receive waste fluid. Other characteristics of aquifers and their contained fluid will be important, depending upon the composition and physical properties of the fluid wastes to be infected. Aspects of the deposits themselves that have direct bearing upon feasibility, cost, operating characteristics, and life expectancy of fluid-waste-disposal systems include geologic structure, sedimentary facies distribution, formation water salinity, and geothermal regime.

Goologic structure is of major importance. In normally pressured sediments, faults that cut unconsolidated deposits of bedded sand and clay can be hydraulic boundaries where clay beds abut sand beds. Synclines 
(troughs or lows) and anticlines (domes or highs) are also important, not only because of structural effects on bed thickness, but also because fluid movement in the past may have resulted in cementation of sandstones, diagenetic alteration of clay minerals, and other changes. Finally, the structural attitude (dip or slope) of many aquifers will appreciably affect movement of waste fluids, especially if the density of injected fluid differs from that of water in the host aquifer. Injected waste fluids, if not chemically compatible with water in the host aquifer, can cause reactions that produce precipitates that can plug the aquifer. Therefore, chemical composition of aquifer water and aquifer material must be known in advance.

The temperature regime of an aquifer system used as a waste-storage reservoir is very important, not only because rates of chemical interactions between waste fluid, host rock, and aquifer water are temperature dependent, but also because viscosity and density of waste fluid and formation water are highly sensitive to temperature. Gravity separation, dispersion rates, differential flow rates, and solubility of dissolved gas are all temperature dependent. Thermal diagenesis of clay minerals in beds overlying and underlying the waste-storage aquifer could result if waste fluids are very hot or if exothermic chemical reactions occur between the waste fluid and formation water or country rock. Diagenesis of clay minerals and possible structural deformation would occur wherever clay beds containing montmorillonite were exposed to temperatures in excess of about $210^{\circ} \mathrm{F}\left(99^{\circ} \mathrm{C}\right)$ (Burst, 1969, p. 77). 
Clay beds containing montmorlllonite, lying above, below, and interbedded with aquifer systems that are used as fluid waste-storage reservoirs, can affect the chemistry of both the wastes and themselves. Montmorillonite has a relatively high base-exchange capacity (a high ionexchange constant) that varies with the degree of compaction (Hanshaw, 1964, p. 397-421) and with lonic strength of water in contact with bed boundaries. In addition, by functioning as semipermeable membranes, clay beds may cause appreclable osmotic flow into or out of an aquifer containing fluid waste. Salinity differences between aquifer waters generate diffusion potentials (osmotic gradients) that can produce very large head differences (McKelvey and others, 1959, p. 199-208). According to McKelvey (written commun., 1966), "the generated osmotic pressures are within 95 percent of the calculated theoretical pressures; that is, a one normal sodium chloride solution versus fresh water ylelds an osmotic pressure of $690 \mathrm{psi}$ " across plugs of Wyoming bentonite in laboratory tests. McKelvey adds that, "water flow under an osmotic gradient appears to be identical to water flow under an equivalent pressure gradient."

Until now, the parameters and fluid mechanics of aquifer systems have never been analyzed on a regional scale in a major depositional unit of clastic rock for the full thickness of the hydropressured zone--the zone in which the pressure encountered at a specific depth approximates the head of a column of water to the same depth. The scope of effort required to obtain all necessary information has been too great, the need for analysis insufficient, or information was not believed to be avallable. 
Fortunately, in this study area, most of the data needed to evaluate methods for the safe and economical subsurface storage of toxic fluid wastes have been collected in the search for petroleum hydrocarbons. Formation waters have been produced in large amounts with petroleum and sampled even where no petroleum was found during tests. Thousands of chemical analyses are available for study. Disposal of those waters and the practice of water flooding provides data on injection experience.

\section{Purpose and Scope}

This is a type-study report designed to test the thesis that the data now avallable in the northern Gulf of Mexico basin are sufficient to enable regional appraisal of subsurface conditions. Standard methods of analysis and interpretation are applied to a representative geologic unit of widespread occurrence in the Gulf coastal plain.

The Wilcox Group of Texas was selected for study because it is a regionally extensive noncarbonate clastic geologic unit including many sandbed aquifers 20 to $100 \mathrm{ft}$ ( 6 to $30 \mathrm{~m}$ ) thick. It is mainly of alluvial origin and is structurally a relatively undeformed unit above a depth of about $6,000 \mathrm{ft}(1,830 \mathrm{~m})$.

The study area is about $100,000 \mathrm{mi}^{2}\left(259,000 \mathrm{~km}^{2}\right)$ and is a belt 100 to $275 \mathrm{mi}$ ( 160 to $442 \mathrm{~km}$ ) wide extending from the outcrop to the gulfward limit of well control (fig. 1). Major aquifer systems that might be considered for subsurface storage of fluid wastes are identified on maps and geologic sections. Their structural conditions are described as they relate to suitability of all, or parts, of the systems for fluid waste storage. 


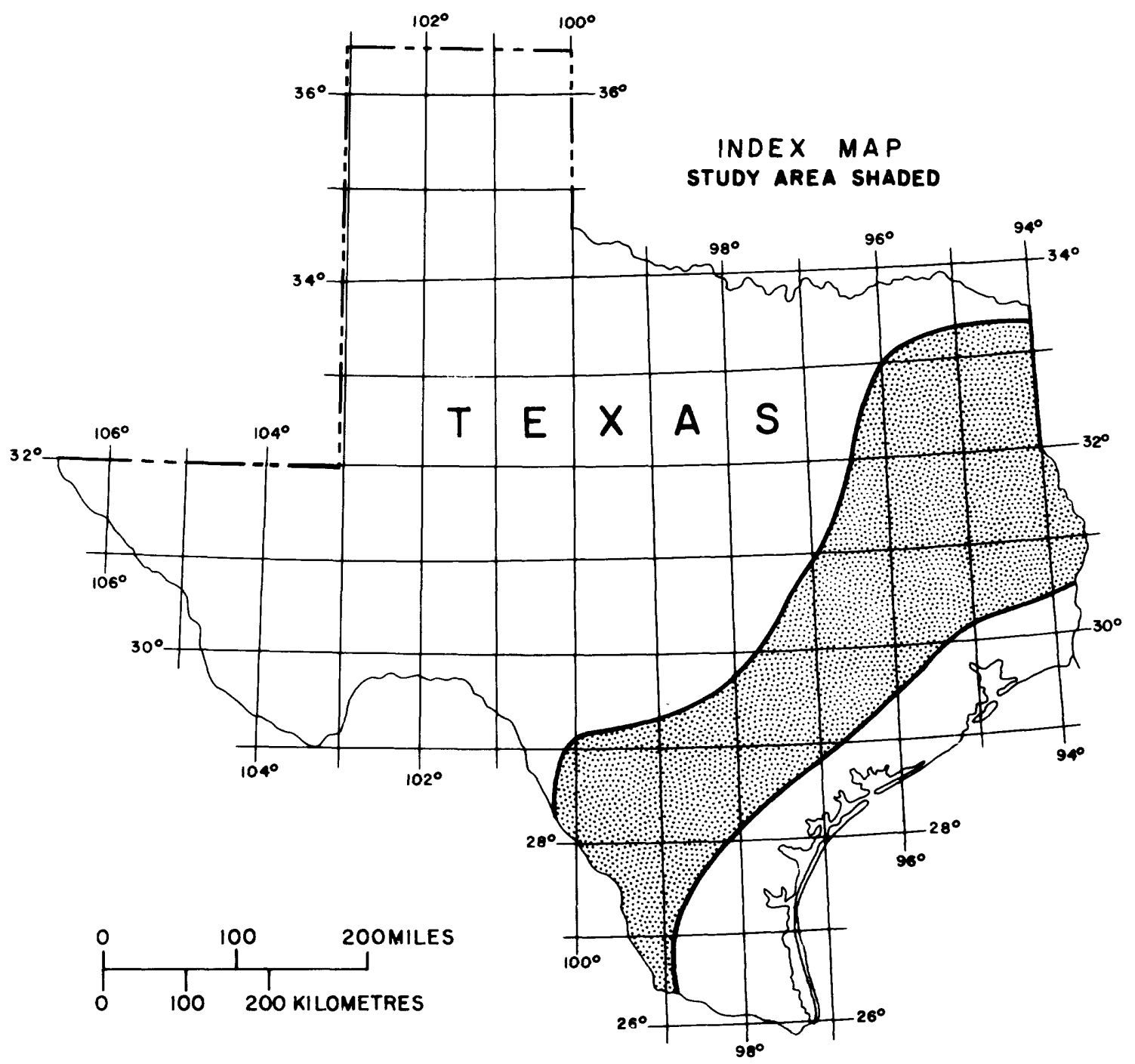

Figure 1.--Study area, Texas. 


\section{Information and Concepts}

Most of the information and many of the interpretations employed in this study are derived from published reports. The most important published contribution to this study is the work by the Bureau of Economic Geology, the University of Texas at Austin. Accomplished under the guidance of Dr. W. L. Fisher, Director of the Bureau, these comprehensive sedimentary facies distribution studies produced guidelines followed in this investigation.

Geopressure, a dominant hydrologic feature of the Gulf basin, is a very important factor in structural deformation. The top of the geopressured zone is indicated on geologic cross sections. Fluid movement upward along fault planes from the zone of geopressure is indicated by isogeothermal profiles shown on these sections. Hot water and heat moving up fault planes from the geopressured zone produce sharp, localized highs. These highs mark zones of present or past hot water release into the hydropressured zone.

A structure map showing the top of the Wilcox for the Texas coastal plain was prepared for this study. This map incorporates published and unpublished structural interpretation from many sources, including Geomap of the Gulf Coast, Inc., the Texas Water Development Board, the Texas Bureau of Economic Geology, and various oil companies with well control. Fault cuts and identification of marker beds--made avallable by oil companies-were also used in the structure study.

Data analysis and interpretation methods of this study are largely standard methods. Concepts employed in the development of sedimentary facies mapping criterla are described in the works of Fisher and McGowan (1967, p. 105-125; 1969, p. 30-54). Techniques included use of spontaneous 
potential and resistivity curves of electric logs for interpretation of depositional environments and depth-related sequences of such environments.

Acknowledgments

Many individuals have contributed directly or indirectly to this study and report. Most of the information on geology and hydrology was derived from oil company well records and from commercial geophysical well logs; well identification data flles and location maps provided by major oll companies made well records usable. Much of the structural information was derived from structural maps prepared by the Geomap Company . Among those most helpful in the data collection effort were T. D. Cook, Gordon Rittenhouse, and H. L. Steward of Shell Oil Company; R. S. Agatston and J. P. McDonald of Atlantic Richfield Company; H. R. Gould of Esso Production Research Company; B. B. Mason of Exxon (Humble Oll and Refining Company); W. R. Walton and G. W. Schmidt of Amoco Production Company; A. T. Hengle and A. T. Ostroff of Mobil Research and Development Corp.; W. A. Fowler of Phlllips Petroleum Company; and B. C. Timm and T. B. Buford of Sun Oll Company.

Analysis and interpretation of subsurface conditions progressed throughout the study, with frequent review and comment by colleagues in oil company research groups, at several universities on the Gulf Coast, and in consulting firms. Especially helpful among these were C. O. Durham, Jr., J. F. Burst, W. A. Fowler, C. E. Hottman, R. H. Kehle, G. W. Schmidt, C. H. Bruce, P. A. Mundt, B. R. Hise, D. J. Timko, H. R. Gould, R. W. Duschatko, and R. S. Agatston.

Dr. W. L. Fisher, Director, Bureau of Economic Geology, the University of Texas at Austin, provided the sedimentary facles distribution maps 
for the upper and lower Wilcox of Texas. Sand-thickness maps for the upper and lower Wilcox and maps for deltas of the Rockdale Delta System were also made avallable by the Texas Bureau of Economic Geology.

Special acknowledgment is made of the personal interest and helpful assistance of J. H. McGowen, V. E. Barnes, and C. V. Proctor of the Bureau of Economic Geology in collection and organization of data provided by the Bureau.

\section{GEOLOGY}

\section{Principal Features}

At the end of Mesozoic time the northern Gulf of Mexico basin was rimmed by carbonate rocks (fig. 2) that were underlain by a thick evaporite sequence including the Louann salt in places. Uplift of the western Cordillera had begun, and effects of Laramide mountain building in the Rockies reached the Gulf basin as a flood of clastic sediments. The oldest Tertiary deposits preserved in most of the Gulf coastal province of North America are of the Paleocene Midway Group (Murray, 1961, p. 370), grading from marine shales upward into prodelta clay and including some sand beds in landward parts of the Texas coastal plain. Following the Midway transgression, the first of eight major cycles of alluviation and delta building in the province began (Lowman, 1949, p. 1987), each separated from its successor by a transgressive marine shale wedge of great areal extent.

The northern Gulf of Mexico has been an active subsiding geosynclinal area since early Eocene. Bornhauser (1958, p. 341) states that "increased structural instability occurred at the close of Eocene time, and during the early Oligocene, when the entire upper Gulf Coast belt, including the 


North
CRETACEOUS South
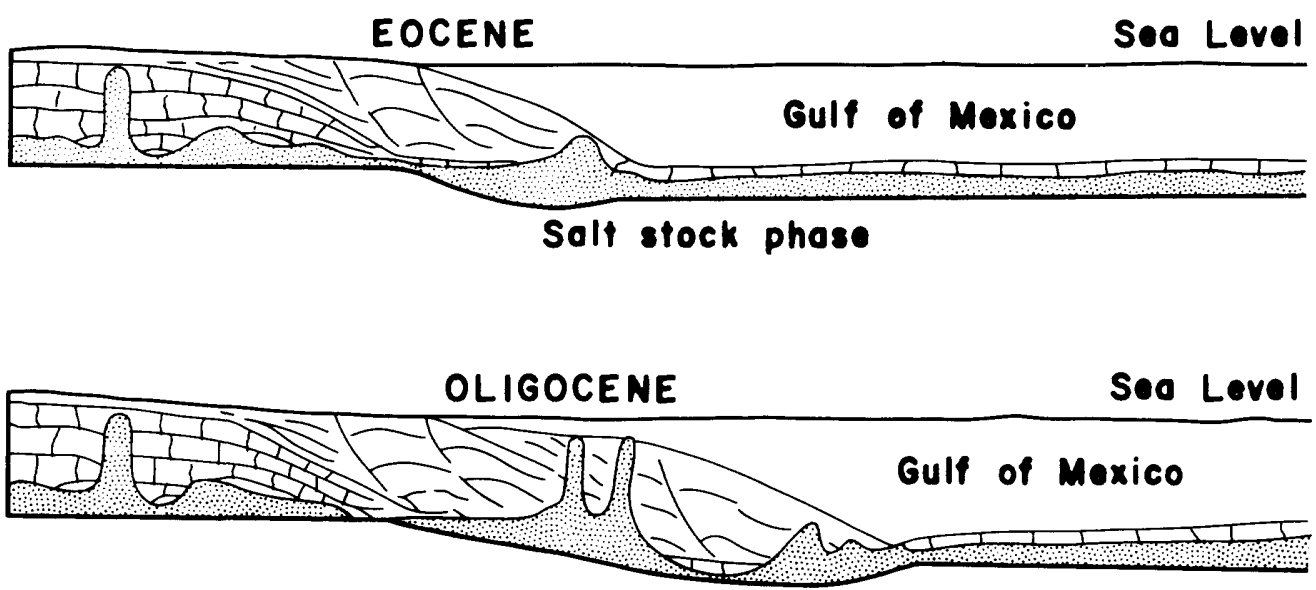

Solf plug phase

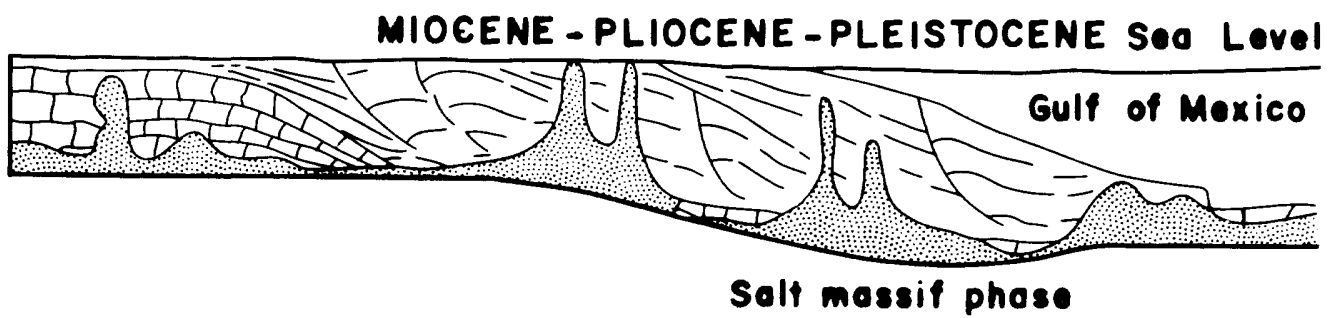

Figure 2.--Stages in the development of the Gulf Coast geosyncline, with salt flowage gulfward under progressive loading, growth of salt stocks and plugs with prograding sedimentation and contemporaneous faulting (Wilhelm and Ewing, 1972). 
Mississippi embayment, was uplifted by epeirogenic movements (which) added to the land area bordering the Gulf Coast geosyncline. This regional emergence caused considerable shrinking of the geosynclinal area, which, however, was accompanied by considerable deepening of the remaining geosyncline." As indicated in figure 2, Eocene deposition in the basin margin resulted in crustal downwarp and development of salt stocks, with indications of contemporaneous faulting of major scale in gulfward components of the sediment mass. A broad coastal shelf extended out on the basin margin, and most of the sandy deposits accumulated at or near sea level--in a range of a few tens of feet (metres) above or below sea level.

Regional uplift in early Oligocene, accompanied by some downwarp of the basin margin, resulted in widespread erosion of Eocene deposits inland and rapid delta building and shelf construction along the northwest margin of the geosyncline. The beveled edge of Eocene fluviatile systems is all that remains in the Texas coastal plain south of the San Marcos arch (fig. 2), but gentle downwarp in the East Texas basin was sufficient to preserve large elements of early Eocene fluviatile systems. Gulfward, the entire thickness of deltaic components is present beneath the Claiborne Group.

Deposits of the Wilcox Group within the study area are largely of alluvial and deltaic origin, formed by ancient streams with headwaters in the rising mountains. Regional structural features of and between the mountains and the Gulf had pronounced effects upon river courses and gradients, type and distribution of deposits, and their subsequent preservation. Most important were the Sabine uplift, East Texas basin, San Marcos arch 
and related Llano uplift, and the Rio Grande embayment. All of these were inherited from the Ouachita System (King, 1959, p. 69), an orogenic belt developed in Late Pennsylvarian time and only slightly modified by Laramide orogeny.

Subsequent deposition in the Gulf Coast geosyncline (fig. 3) (Barton and others, 1933, p. 1446-1458) had great effect upon deposits of the Wilcox Group, in terms of structural deformation, geothermal and hydrologic regimes, and occurrence of oil and gas. Today, the geosyncline is a major structural trough at the continental margin. It is 350 to $600 \mathrm{mi}$ (563 to $965 \mathrm{~km})$ wide and $800 \mathrm{ml}(1,287 \mathrm{~km})$ long; maxtmum cumulative thickness of Tertiary deposits along its axis, which roughly colncides with the modern coastline, exceeds $50,000 \mathrm{ft}(15,240 \mathrm{~m})$ in two depocenters, one off the south Texas coast and the other beneath coastal Louisiana (fig. 3).

A significant aspect of Wilcox structural deformation with continuing geosynclinal fill resulted from salt flowage and diapirism. As shown in figure 2, salt flowage has been a dominant factor in structural evolution of the geosyncline--in both those areas where it originally occurred in Mesozolc rocks and in adjacent areas gulfward. Plastic flow has resulted in large-scale displacement of overlying deposits. Lows mark subsidence in areas from which salt flowed, whlle resultant ridges and domes uplift and commonly rupture, overlying clastic deposits (Lehner, 1969, p. 2431-2479) .

Shale tectonics is similar to and sometimes coupled with salt tectonics but has its own set of structural controls (Bruce, 1972, p. 23-31). Structural deformation, related to fluid mechanics of pressured shale, is a function of the abundance of shale and its distribution in the geosyncline. Perhaps 60 


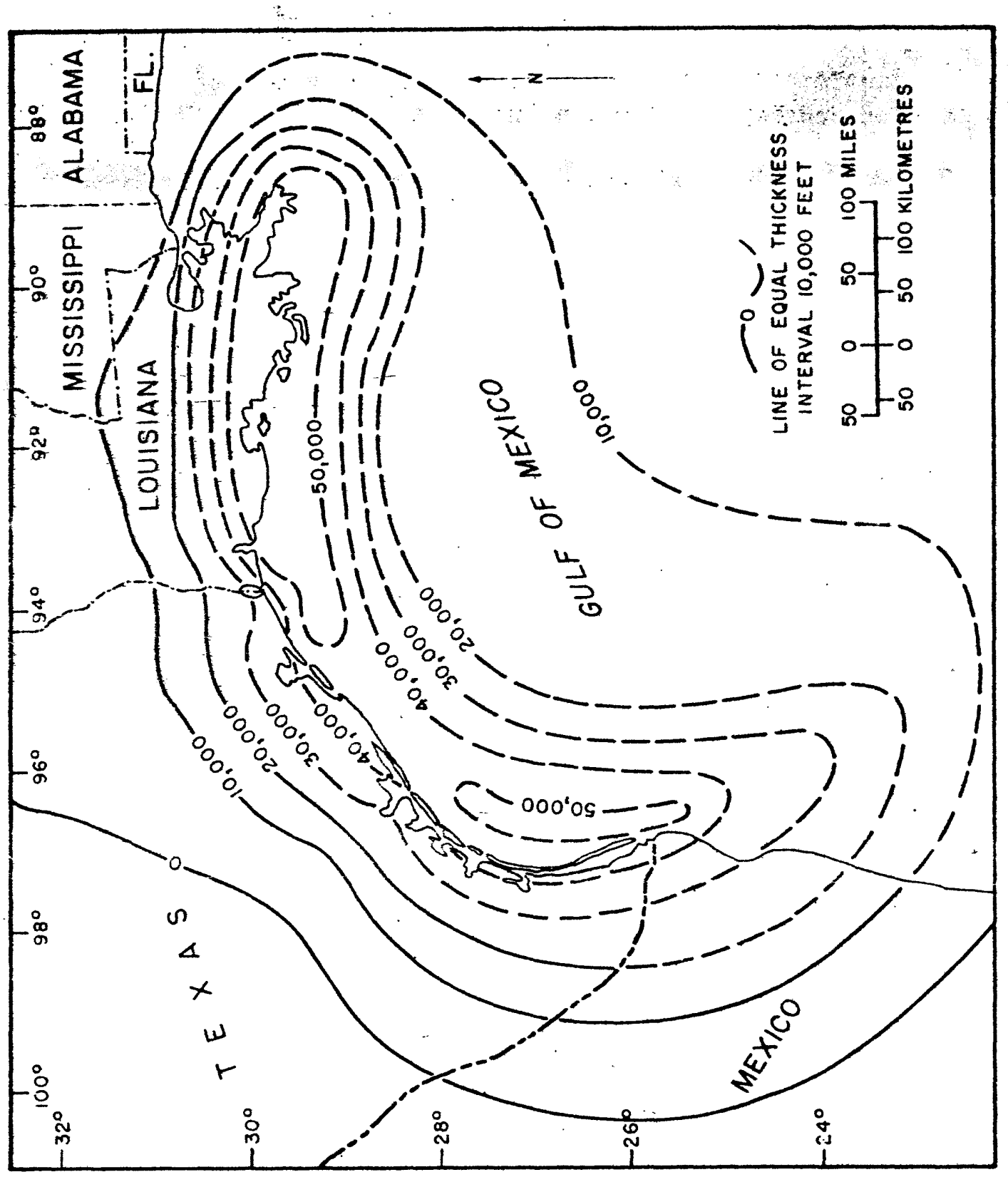

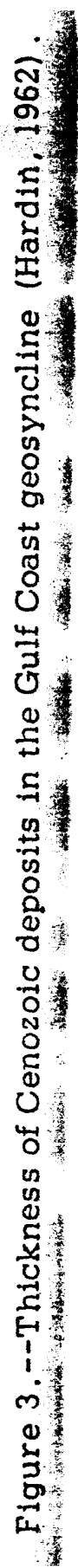


percent of the sedimentary fill was deposited as prodelta and marine mud. This mud was overridden by prograding deltas, mainly beds of quartz sand with interbeds of clay, as shown in flgure 4. Progressive compaction of relatively incompetent marine clay or shale by overlying deltaic or delta front sand resulted in shearing forces; faulting occured and downward movement kept pace with or exceeded continuing deposition. Such contemporaneous normal faulting, known as growth faulting, localized large sand deposits and is the most distinctive structural feature of the Gulf Coast geosyncline (OCamb, 1961, p. 139-175).

Locations of important regional faults are shown in figure 5. As suggested by fault patterns in figures 4 and 5 , growth faulting characterizes the distal parts of each major depositional cycle in the Gulf Coast Cenozoic. Fault trends roughly parallel the modern coastline. In plan, belts of faults are formed by intersecting arcuate faults; splits in which each fault segment shares a part of total displacement are common.

Sedimentation and structural deformation in the geosyncline have gone hand-in-hand through Tertiary and Quaternary time (Krumbein, Sloss, and Dapples, 1949, p. 1859-1891) . Factors directly or indirectly related to distribution of sediment types and to the mineralogy of the sediments themselves had profound effect upon the structural evolution of the northern Gulf of Mexico basin. Principal among these factors was the geothermal regime and its interdependent hydrologic regime. The latter, through the phenomena of geopressure (Jones, 1969a, 105 p.; Jones, 1969b, p. 803$810)$, is perhaps the most important, as confined pore water causes rock to resist deformation if water cannot escape. Compressional stress is 


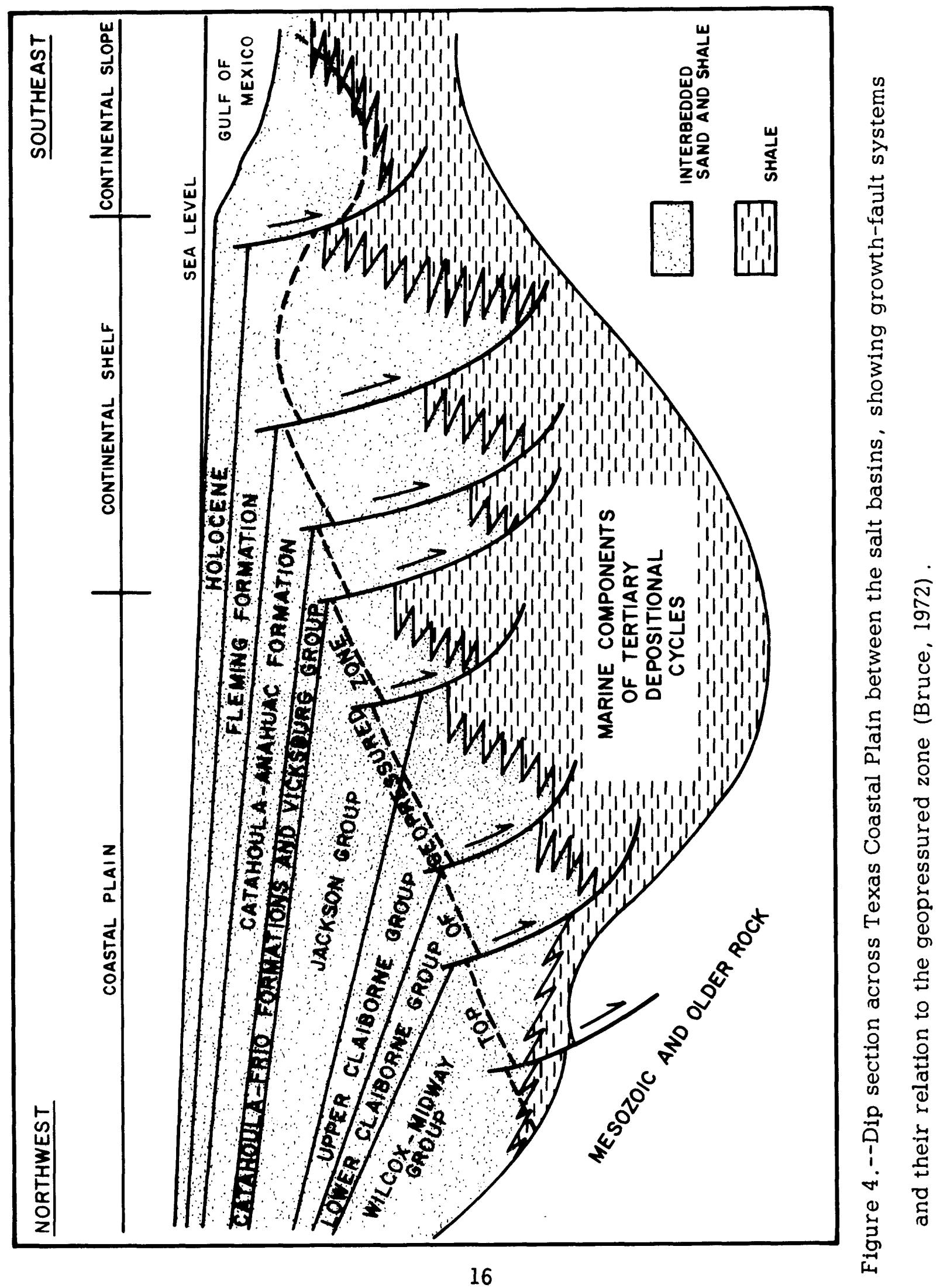




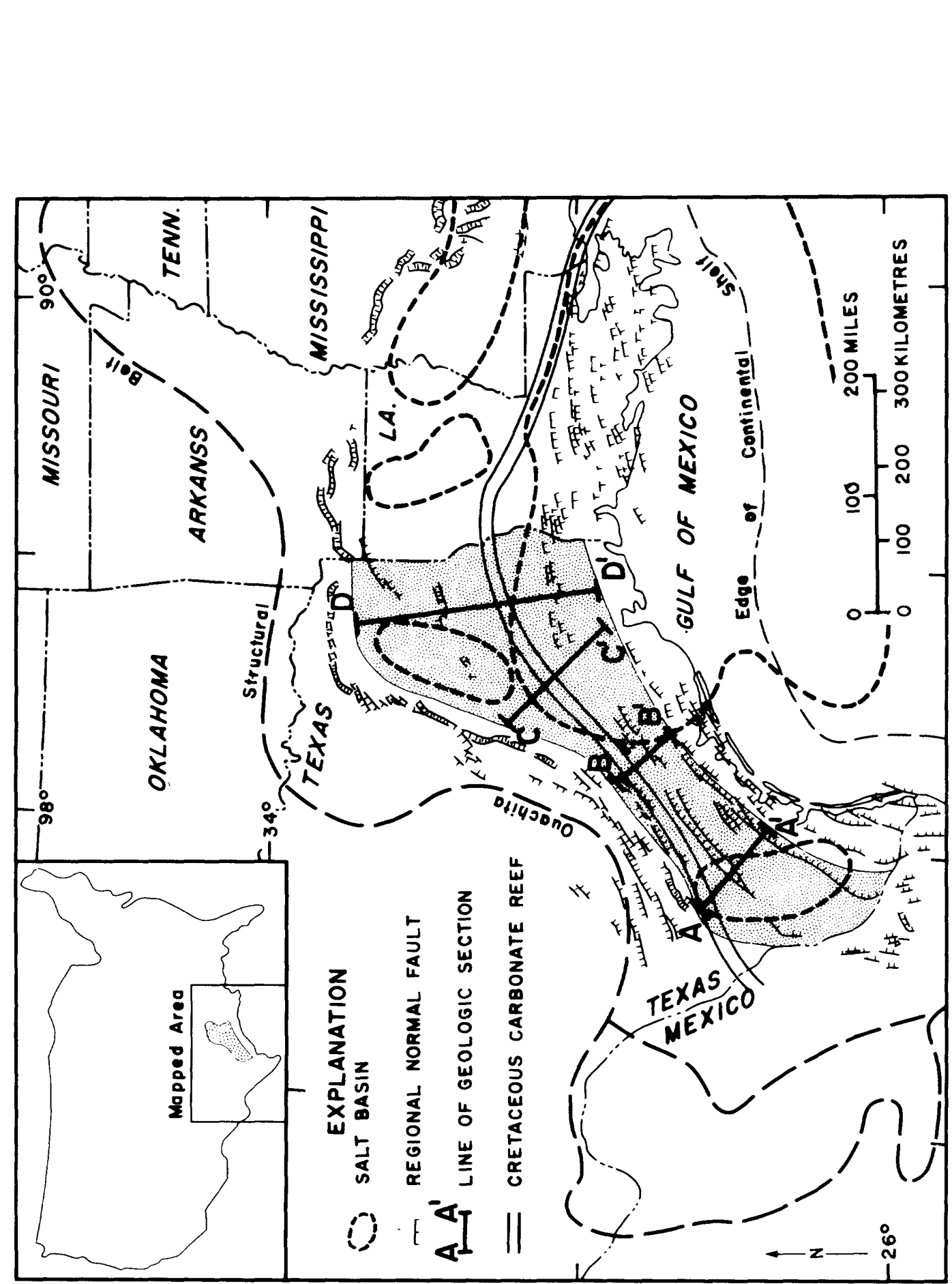

్ㅗㄹ

?

$\leftrightarrows$

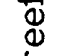

空

5

ह

0

ก

0

芒

$\stackrel{8}{2}$

ఫ

$\pi$

这

(2)

ㅇ.

0

.

응

o

in

㟧

出

(5)

密

员 旁

i 
distributed through geopressured deposits according to Pascal's Law (Pressure applied to an enclosed fluid is transmitted equally in all directions without loss and exerts equal force on equal areas.) in such a way that the locus of shear and its dip angle are functions of local pressure gradient (Bruce, 1973, p. 880).

Fault planes in the geopressured section are principal avenues of water movement. As pressured water escapes upward into the hydropressured zone, faults along which it moves propagate further into the pressured shale. Water lost to the fault plane allows adjacent shale to compact. The fault network grows into the shale in a branching pattern determined by drainage. Water escaping upward is warmer than the overlying rocks, and isothermal surfaces are warped upwards. Where escaping hot water follows sand-bed aquifers of major deltaic systems, its movement is evidenced by regional upwarp of isotherms. Important hydrologic inferences can be made by analysis of relations between geotemperature, geopressure, geologic structure, and sediment facies.

Movement of hot water from the geopressured zone into the hydropressured zone may have profound effect upon geologic structure if the temperature of the water is high enough to cause thermal diagenesis of montmorillonite--that is, if the temperature of the water is in the range of $210^{\circ} \mathrm{F}$ to $275^{\circ} \mathrm{F}$ (about $99^{\circ} \mathrm{C}$ to $135^{\circ} \mathrm{C}$ ) (Burst, 1969, p. 77). As thermal dlagenesis of clay minerals occurs, load-bearing strength of clay beds adjacent to sand beds carrying the hot water is reduced; the clay beds lose pore water into adjacent sand beds, and subsidence of overlying rocks occurs. Heating by water influx, diagenesis of clay minerals, re- 
lease of bound and intracrystalline water, and differential compaction where changes in the sand-bed clay-bed thickness ratio occurs cause rock shearing forces that spread from the location of hot-water leakage. As post-depositional faulting in the hydropressured zone is induced by hot-water influx, the resulting fault zone progressively widens through geologic time. This occurs as a function of the hydrothermal regime and without need for tectonic stress differentials in underlying rocks.

Distribution of sediment types, or facies, in the Wilcox reflects two major aspects of structural control: first, those inherited from the Ouachita System (arches and basins), and second, those developed contemporaneously with sedimentation (growth and post-depositional faults and dlapirs).

Regional distribution of sediment facies along the basin margin is primarily a function of inherited structure (pls. 1-8). The Rio Grande embayment, San Marcos arch, and East Texas basin (fig. 6) had great effect on sediment facies and on thickness of deposits in the lower Wilcox. In a coastwise belt some $20 \mathrm{ml}(32 \mathrm{~km})$ wide at the San Marcos arch and broadening to about $70 \mathrm{ml}(113 \mathrm{~km})$ some $160 \mathrm{ml}(257 \mathrm{~km})$ northeastward, cumulative thickness of sand beds in the lower Wilcox is as much as $2,400 \mathrm{ft}(732 \mathrm{~m})$ and is more than $2,000 \mathrm{ft}(610 \mathrm{~m})$ throughout much of the area. Southwestward from the San Marcos arch, cumulative thickness of sand beds in the lower Wilcox exceeds $2,000 \mathrm{ft}(610 \mathrm{~m})$ in only a few small areas (pl. l). 

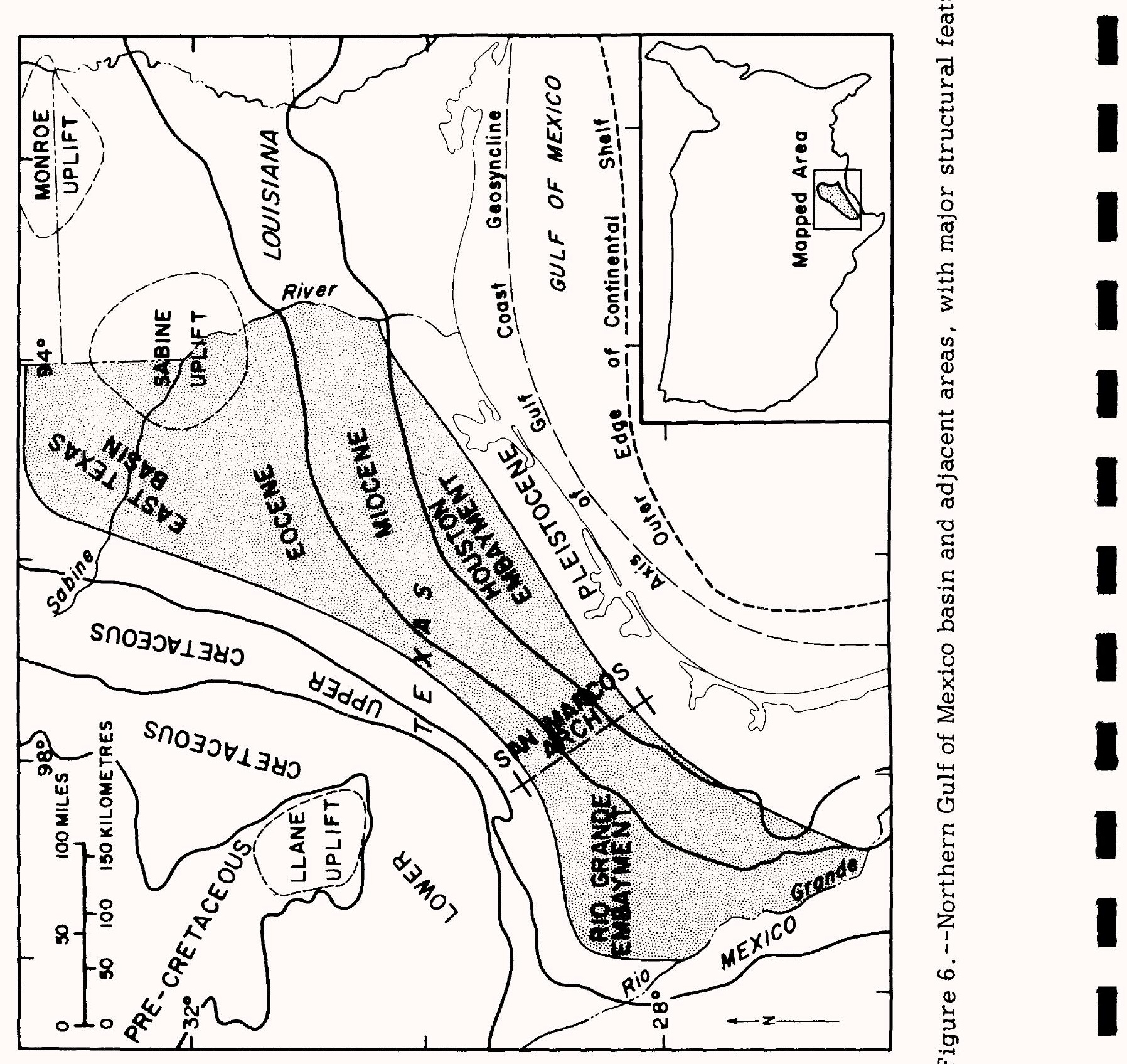
Effect of the San Marcos arch upon sediment facies distribution in the upper Wilcox is much less apparent, probably because lower Wilcox sedimentation had blanketed it deeply and smoothed the coastal plain and shelf. The broadest and thickest accumulation of sand beds in the upper Wilcox is southwest of the San Marcos arch where cumulative thickness exceeds $1,000 \mathrm{ft}(305 \mathrm{~m})$ in a coastwide belt up to $20 \mathrm{mi}(32 \mathrm{~km})$ wide and almost $45 \mathrm{mi}(72 \mathrm{~km})$ long (pl. 7).

Maximum observed thickness of the middle Wilcox marine shale is $3,000 \mathrm{ft}(914 \mathrm{~m})$ in the Yoakum Channel near the town of Yoakum in southern Lavaca County (pls. 6 and 8), along the northeast flank of the San Marcos arch (Hoyt, 1959, p. 41-50). Elsewhere, along the gulfward margin of the mapped Wilcox, it is about $600 \mathrm{ft}(180 \mathrm{~m})$ thick.

- Interrelations among sediment facies, geopressure, geotemperature, and geologic structure are complicated and difficult to generalize. However, both locally and regionally, they have very great significance on the hydrology of the Wilcox Group.

\section{Stratigraphy}

The Wilcox Group is underlain throughout the Texas coastal plain by sediments of the Midway Group (Paleocene), and overlain by sediments of the Clalborne Group (middle Eocene). Wilcox beds are predominantly argillaceous (and in places quite calcareous); basal Clatborne beds (Reklaw-Cane River) are argillaceous and calcareous throughout all but the southernmost part of the Texas coastal plain. The top of the Midway and base of the Claiborne are identified on the basis of lithology--except in the upper Rio Grande embayment area where uppermost Wilcox and basal 
Claiborne deposits are both fluvial channel sands, and the stratigraphic break cannot be identified with confidence.

MIDWAY GROUP.--In eastern and central Texas the Midway consists of (1) The Kincaid Formation, a thin basal calcareous-argillaceous chalky clay, (2) the Wills Point Formation, a thick middle carbonaceous, laminated, micaceous to slightly arenaceous clay, and (3) the Solomon Creek Member of the Wills Point Formation, a thin upper arenaceous clay (Murray, 1961, p. 372). Cumulative thickness of these formations downdip is about $3,200 \mathrm{ft}(975 \mathrm{~m})$ in the Rio Grande embayment according to Murray. However, at depths less than about $4,000 \mathrm{ft}(1,220 \mathrm{~m})$ the Midway is less than $600 \mathrm{ft}(183 \mathrm{~m})$ thick in the embayment. Along the San Marcos arch it thins, and northeastward it thickens rapidly. The Midway Group is the basal unit of this study.

WILCOX GROUP.--Murray (1961, p. 374) suggests the term "Wilcox Group" be used in a rock-group sense, rather than in a time-rock sense. In this report, his recommendation is followed. Stratigraphic nomenclature is informal and is herein called upper, middle, and lower units of the Wilcox Group, mainly following that of Fisher and McGowen $(1967,1969)$. No attempt is made to identify and trace in the subsurface, formations recognized and named in the outcrop. This would be folly, as evidenced by depositional patterns shown in the maps and sections.

Fisher (1971, p. 3) characterizes the two major delta systems of the Wilcox Group as "high constructive" (lower Wilcox) and "high destructive" (upper Wilcox), referring to the relative intensity of deltabuilding processes and delta-eroding processes at the marine fringe. The systems are described as follows: 
"High-constructive delta systems (for example, Lower Wilcox, Yegua, and Jackson) are comparable in scale and facies to Holocene Mississippi Deltas. They were supplied by rivers with large-volume sediment discharge; fluvial facies are concentrated locally along the basin margin. These deltas consist dominantly of fluvial and fluvially-influenced deposits, with extensive coal-bearing delta plain facies, thick progradational delta front sand facies, and very thick organic-rich prodelta mud facies. Progradational sand facies show elther lobate or elongate patterns in plan. Delta systems of this type supported extensive strike-fed systems comparable to strand-plain and barrier bar systems of the Holocene northwestern Gulf Coast.

"High-destructive delta systems (for example, Upper Wilcox and Frio) are analogous to the Rhone and other Holocene deltas with significant marine modification (chiefly wave action) of fluvially-introduced sediments. These deltas were supplied by numerous, relatively small rivers with moderately high sand load; updip fluvial facies persist along the entire basin margin. High-destructive deltas are composed of a series of sand bodies with thickness axes roughly parallel to regional strike. Each of these deltas consists of local progradational sand facies (channel and channel mouth bars) flanked marginally by extensive sand units reworked from channel mouth bars. Associated prodelta mud facies is moderately thick to thin. High-destructive deltas supported local rather than areally extensive strike-fed systems." Separating these two systems throughout most of the area is a transgressive marine shale. 
Total thickness of the Wilcox Group in Texas ranges from about 500 $\mathrm{ft}(152 \mathrm{~m})$ to $3,000 \mathrm{ft}(914 \mathrm{~m})$ along the outcrop, thickening northeastward from Zavala to Milam County and then thinning to about 2,000 ft $(610 \mathrm{~m})$ in Nacogdoches County, farther to the northeast. Southeastward (downdip), the group thickens to more than $6,000 \mathrm{ft}(1,830 \mathrm{~m})$. Maximum thickness of the Wilcox Group is unknown.

Study Methods.--In the last 40 years, intensive studies have been made of Pleistocene and Holocene deltaic and near-shore marine sedimentation in the northern Gulf of Mexico basin. Detailed knowledge of recent depositional history has become the basis for analysis and interpretation of depositional processes by which sedimentary rocks were formed in the distant geologic past. Following the early work of Russell (1940, p. 11991233), Fisk (1944, 78 p.), and Storm (1945, p. 1304-35), and during the work of Krumbein (1948, p. 1909-1923), Krumbein, Sloss, and Dapples (1949, p. 1859-1891), Lowman (1949, p. 1939-1997), and the later work of Fisk and McFarlan (1955, p. 279-302), intensive studies of sedimentation at the basin margin were undertaken by geological departments of several oil companies. During the past two decades, results of these studies and the work of State and Federal geological surveys have contributed to knowledge and understanding of sedimentary tectonics and environments of the northern Gulf basin. The most comprehensive studies (for which reports have been published) of depositional systems that comprise major preQuaternary geologic formations in the Gulf basin were made by the Texas Bureau of Economic Geology, under the leadership of Fisher and McGowen (1967, p. 105-125; 1969, p. 30-54). Their classification of depositional 
systems of the Wilcox Group consisted of facies Identification and mapping on the basis of established relationships between facies and environment of deposition. Reconstruction of depositional systems required threedimensional analysis and mapping based on key parameters (LeBlanc and Bernard, 1954, p. 185-194; LeBlanc, 1972, p. 133-190).

Selection of key parameters--the features of a deposit that uniquely define its environment of origin or deposition--was based upon models. One replicates the valley of the modern Mississippi River downstream from the Arkansas-Louisiana State boundary to the Gulf of Mexico, and another replicates conditions in the area near the mouth of the Rio Grande.

Facies means aspect, and a sedimentary facies is an assemblage of commonly related rock properties, such as composition and texture, fossil assemblage, thickness and lenticularity, and geometrical form. According to Lowman $(1949$, p. 1948), "the term facles is commonly used in a way that implies horizontal change in the character of the sediments ***," and indeed, this horizontal variation is directly related to processes of sedimentation.

Sedimentation.--The origin and physical characteristics of fluviatile, deltaic, and nearshore marine deposits are primarily functions of moving water (Pettijohn, 1949, p. 590-596). According to Hjulstrom (1939, p. 5): "The transport of detritus by moving water is affected by many factors, the most influential of which is the velocity of the water. Particles are transported individually or collectively. Transport of individual particles is in four types: sliding, rolling, saltation (Jumping), and suspension .. . With increasing velocity the mode of transport ordinarlly passes successively through these four states of transport. The particles also may 
move collectively, that is, in masses. In this way are formed such features as ripples, bars, and banks.

"The laws governing the different kinds of transportation are complicated. For particles larger than sand ( 0.5 millimetre) the size of particles that can be put in motion increases as the velocity of the water becomes greater; but for smaller particles the minimum velocity that is required in order to bring them into suspension does not decrease as the particles become smaller; instead, it increases. Thus it is easier to move sand off the bottom than silt. Once a particle is in motion it cantinues to be transported until the velocity of the water decreases to a certain speed. This minimum transporting velocity for particles of sand size or larger seems to be about 30 percent less than the velocity needed to remove the particles from the bottom; but for progressively smaller particles, the minimum transporting velocity becomes increasingly less in proportion to the velocity required to make the particles go into suspension."

Figure 7 shows the relationship between particle size and mean velocity of water and indicates whether the particle is eroded, transported, or deposited at a given velocity. A model of sediment sorting and dispersal by moving water--in which particle size is fundamental--has a sound basis in physics.

Sediment facies, or aspect, is also a function of post-depositional changes, including cementation, diagenesis, and solution. These changes are also related to movement of water, that is, between particles and around them. Here again, size of particle and degree of sorting (uniformity of texture) have a marked effect. Thus, sediment facies is the product of 


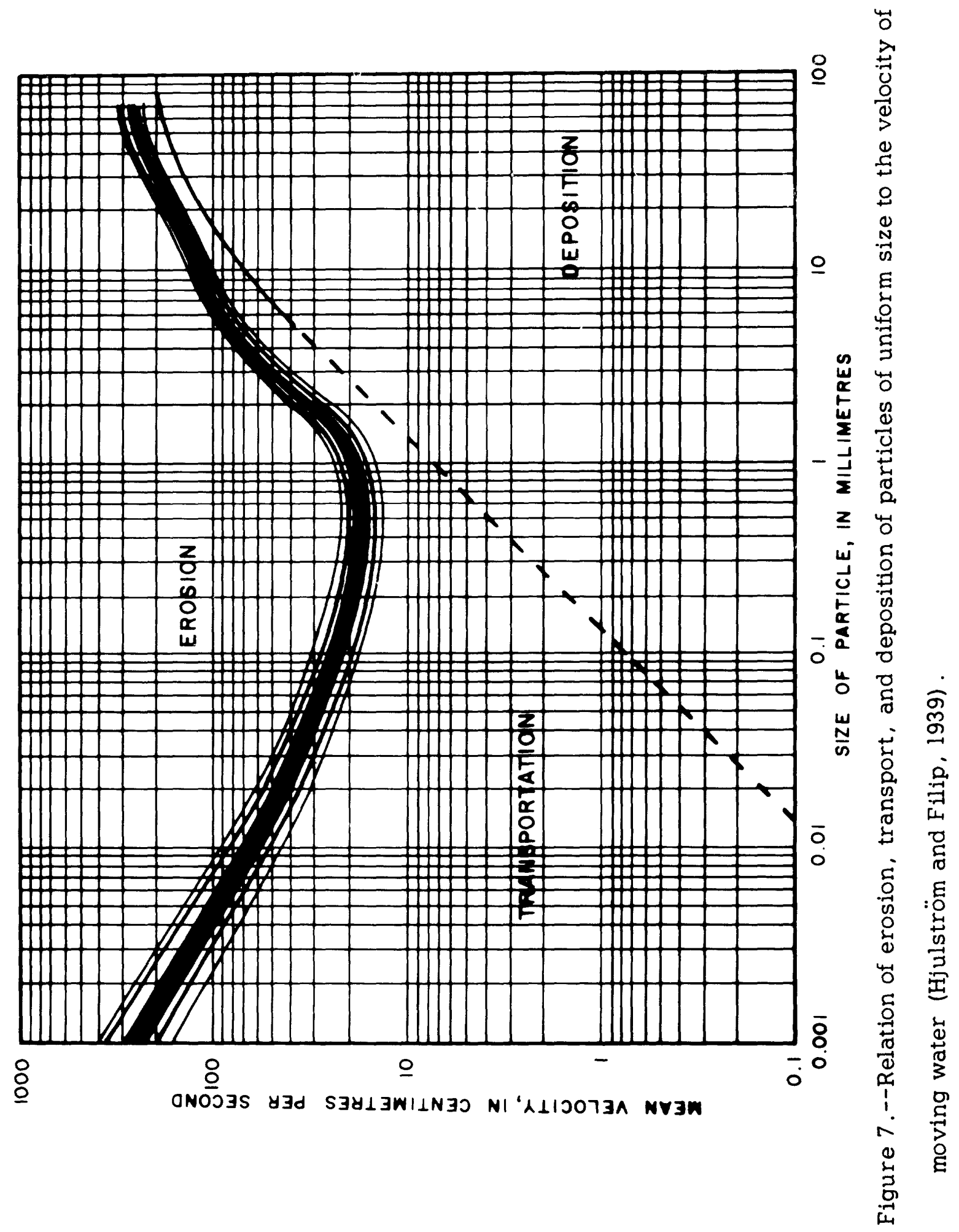


both depositional environment and change after deposition. According to Lowman (1949, p. 1949), criteria useful in identifying depositional environments include the following static variables: (1) Gross mineral composition of the solid rock, for example, limestone, shale, or sandstone; (2) size, shape, and distribution of detrital grains; (3) fossils; (4) sedimentary structures; and (5) possibly some mass effects related to chemical composition, such as radioactivity and magnetic properties. In addition, Lowman states that the following dynamic variables might be considered: (l) Minor changes in gross composition, for example, limestone to dolomite; (2) cement; (3) chemical composition of rock fluid; (4) character of those parts of the mineral assemblage which are susceptible to post-depositional change through differential loss of some minerals and authigenic gain of others; and (5) some physical mass properties such as density and porosity.

Information on static variables may enable recognition of depositional environment, and data regarding dynamic variables may provide clues to post-depositional changes in deposits. Fitting data and interpretations into depositional models based on studies of modern deltas provides a satisfactory method of three-dimensional analysis--providing the correct model is used. Morgan $(1970$, p. iv) states that "Because of the diversity in types of information obtained and amount of detail available, it is very difficult in most instances to make direct comparisons between modern and ancient deltas. Such comparisons, of course, are the ultimate goal of most investigators who are attempting to explain ancient deltas in the light of modern deltaic processes and sedimentary sequences. At present it must be recognized that there is not sufficient information available to make 
detalled and adequate comparisons." Without direct comparisons, but with knowledge and understanding of deltalc sedimentation, satisfactory depositional models may be developed.

Morgan $(1970, p .31)$ has defined four basic factors that control and influence delta formation:

"1. river regime, mainly particle size and quantity of material transported by a river to its delta and variations in these properties during seasonal fluctuations in flow;

2. coastal processes, essentially the influence of waves, tides, and currents on the seaward margins of the deltaic environment;

3. structural behavior and the relation of sea level to the depositional site; for example, is the delta prograding across a stable platform, or is the area subsiding contemporaneously with sediment deposition, and are these changes occurring in a background of stationary, rising, or falling sea level; and

4. climatic factors, particularly those that affect vegetation within the delta."

Fisher and McGowen (1967, p. 120) have considered these factors in constructing the Wilcox delta models. They recognized that the dominant factor in analysis of sediment facies is the sand dispersal pattern. Grainsize distribution and geometry of sand bodies are determined by the energy of moving water in which the sand was transported and deposited. Again, the curves of Hjulstrom (fig. 7) provide insight into the interplay of environmental controls. For example, energy required for transport of sand, in terms of water velocity, is greater than that for silt or clay, but energy required to erode fine sand is less. 
Mapping Techniques.--The early work of Russell (1940, p. 1199-1233) and Fisk $(1944,78$ p.) in the lower valley of the Mississippi River (Cairo, Ill. to the Gulf of Mexico) was accomplished by study and interpretation of lithologic logs and drill cuttings for about 60,000 borings and examination of countless outcrops. Both Russell and Fisk recognized that patterns of sand dispersal provide a key to reconstruction and mapping of fluviatile, deltaic, and related marine-marginal depositional systems. Electric logging of boreholes became common practice by 1950, and many investigators learned to recognize specific types of sand deposits on electric logs, mainly by characteristic shapes of the spontaneous potential curves on the logs (see Krueger, 1968). Manuals on sand conditions, as indicated on electric logs (especially the spontaneous potential log) have been prepared by geological departments of several oil companies.

Although electric-log interpretation is useful to the log analyst engaged in identification and mapping of sand-dispersal systems with electric logs, a comprehensive knowledge of basic principles is not necessary for effective work. Sand-dispersal systems and sediment facies can be identified by the shapes of log curves which have genetic implications. Shape of the spontaneous-potential curve for a sand body indicates physical characteristics of the sand bed in two dimensions, and provides clues to depositional environment, texture, uniformity of thickness, areal continuity, and degree of interbedding of sand and clay. Thickness of sand beds can be measured with great accuracy on the electric log. Guidelines for appraisal of electiclog curves for sand bodies have a sound basis in geologic and geophysical principles, but they were developed empirically. 
Certain limitations on electric-log interpretation should be recognized. For example, the spontaneous-potential curve does not provide information on sand texture directly. The potential recorded on the log is primarily a measure of electrochemical potential differential between an electrolyte in the borehole (the water of a water-base mud) and the water in the sand body penetrated by the borehole. However, dispersed clay particles in a sand bed, which are electrically conductive solids, tend to reduce the observed electrochemical potential. Because relative abundance of dispersed clay particles increases as sand particle size decreases, attenuation of the amplitude of the spontaneous-potential curve is associated with decreasing sand grain size. Thus, the spontaneous-potential curve amplitude (its departure from shale base) has no relation to sand-bed porosity (Jones and Buford, 1951, p. 115-139) .

Resistivity of a sand bed recorded on the electric log can be analyzed in terms of porosity of the bed. Both spontaneous-potential and resistivity curves enable estimation of the salinity of interstitial water in a sand bed. If formation water is fresh, electrical resistivity is a function of grain size (texture) of the sand, and the resistivity curves can be analyzed in terms of sand permeability (Alger, 1967, p. 18).

In summary, the shape of the spontaneous-potential curve indicates the following:

1. Homogeneity of the sand unit; the sand bed may be comparatively massive (without shale interbeds), or it may consist of interbedded sand and shale. 
2. Vertical variation of grain size (texture), or degree of interbedding with shale; the grain size of sand or thickness of shale interbeds may increase or decrease in a systematic and characteristic manner in a direction normal to bedding.

3. Nature of the lower contact; the lower sand-shale contact may be gradational or abrupt.

4. Nature of the upper contact; the upper sand-shale contact may be gradational or abrupt.

Thus, genetically significant properties of a sand body are indicated by the shape of the spontaneous-potential curve (fig. 8). If it is serrate, the sand is broken by shale interbeds; if smooth, the sand is massive. If the curve changes sharply, lithologic changes are abrupt; if gradually, lithologic changes are gradational. Representative log patterns showing systematically stacked sequences of different origin in the lower Wilcox are shown in figure 9.

Mapping techniques based on these methods were used in studies of the lower and upper Wilcox by the Texas Bureau of Economic Geology . Electric-log analysis methods described above were applied in facies identification and correlation on geologic sections.

The model of sedimentary environments used by Fisher and McGowen $(1967$, p. 121) to identify and map sediment facies in the lower part of the Wilcox Group is shown in figure 10. The model is called an idealized sand-dispersal system because "The dispersal pattern of coarser fraction sediments (generally sand) in a terrigenous clastic system provides significant clues to the origin of specific facies and also provides a basis for 


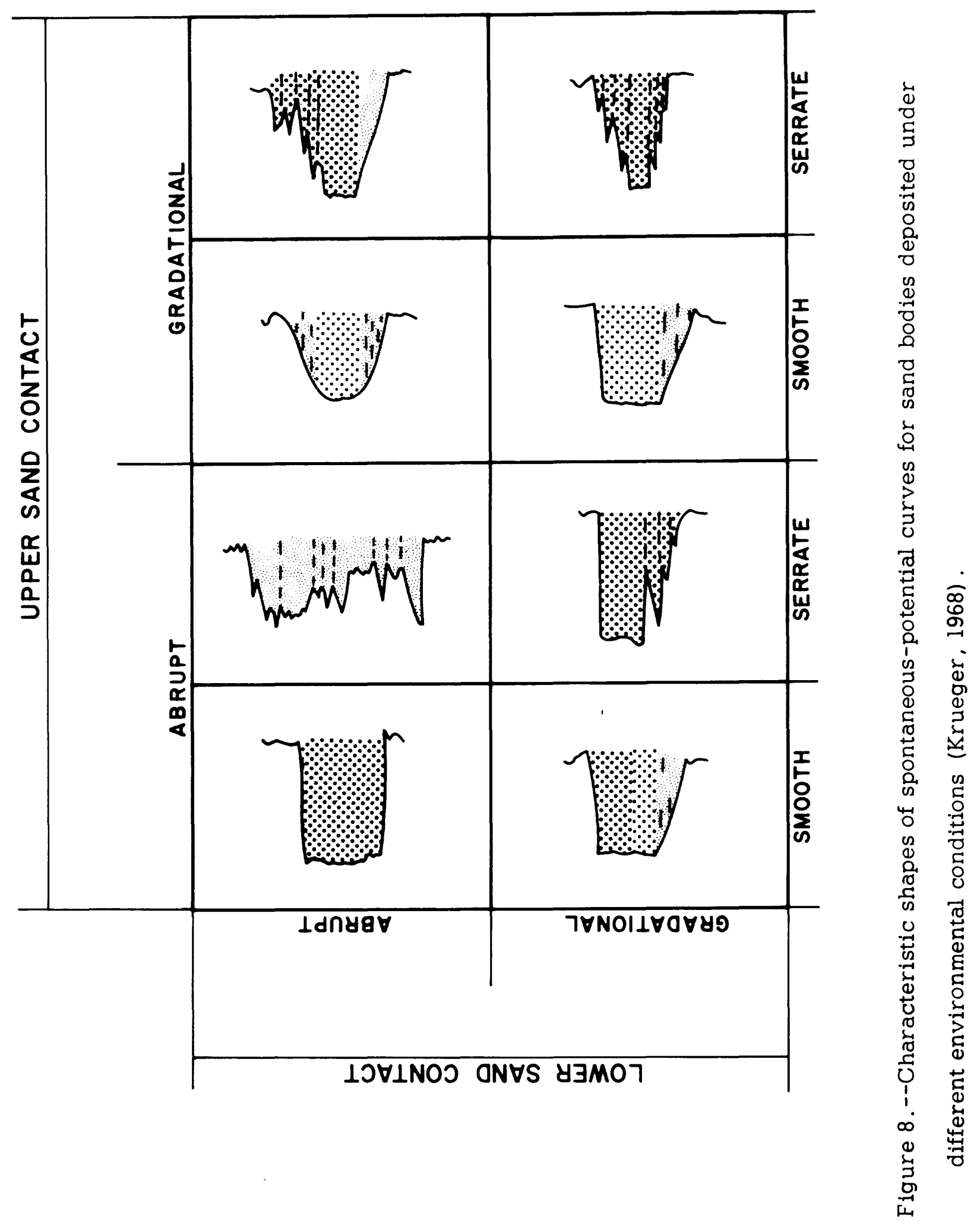



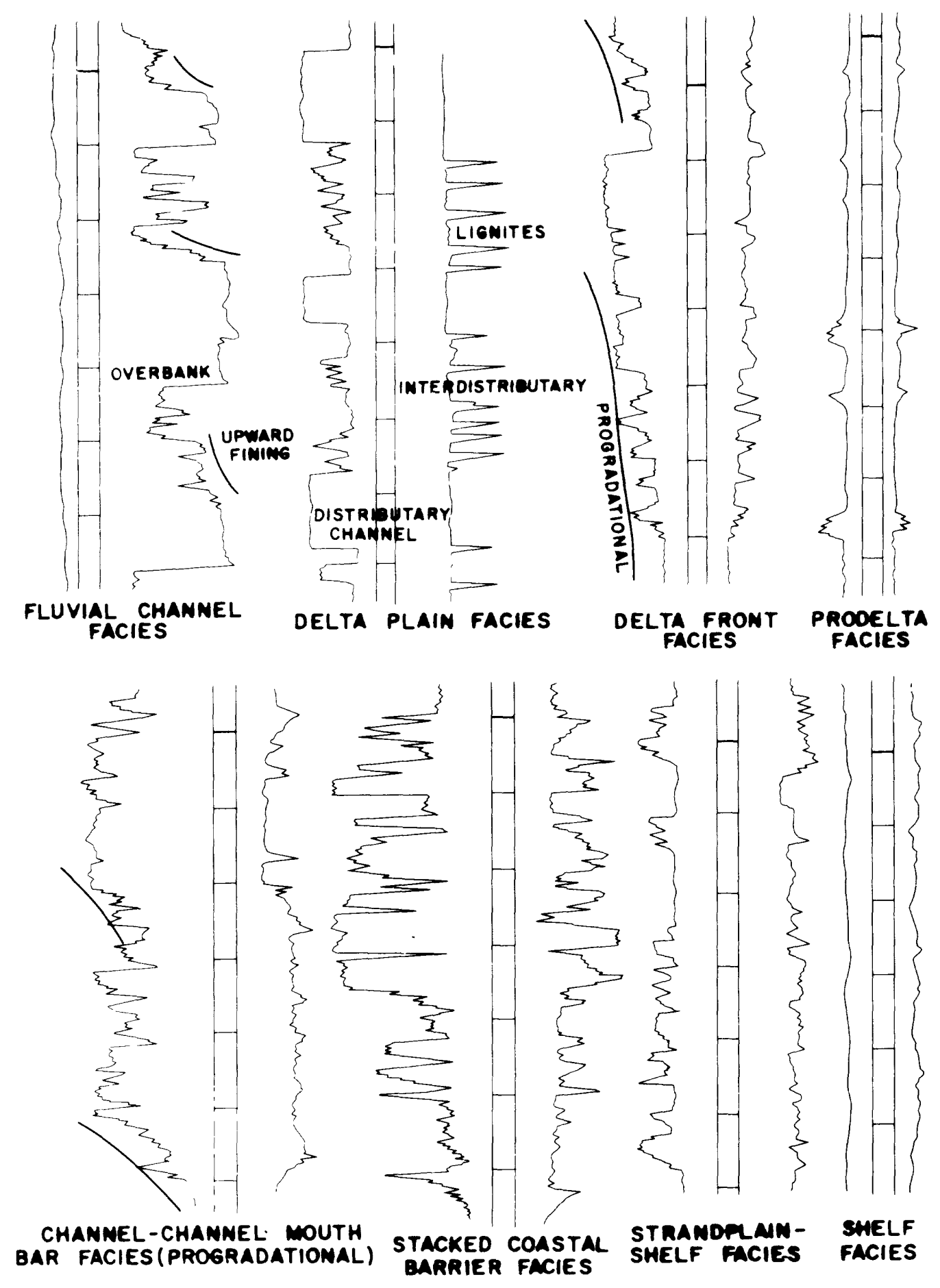

Figure 9.--Representative electric log patterns in each of the major depositional systems of the lower Wilcox in Texas (modified from Fisher, 1969a). 


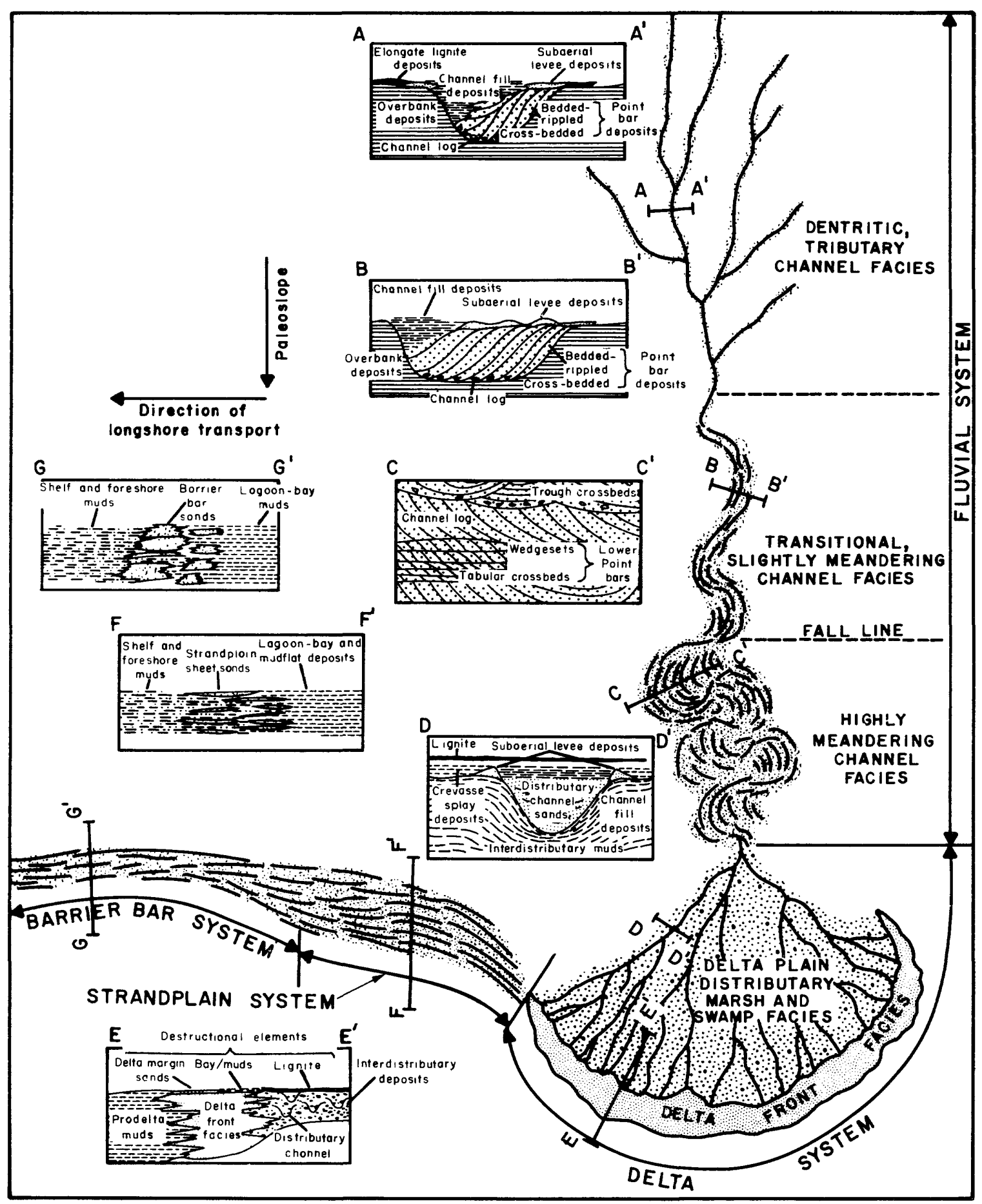

Figure 10.--Idealized sand-dispersal patterns in each of the principal depositional systems of the Wilcox Group in Texas (Fisher and McGowen, 1967). 
the integration of various facies and systems" (p. 120). Each of the principal sand-dispersal patterns is described and named; correlative patterns mapped in the subsurface Wilcox are given corresponding names, with appropriate geographic or geologic modifiers .

In figure 10, seven sand-dispersal systems are described that have characteristic sediment facies recognizable and mappable in the subsurface Wilcox. These are, in gulfward progression: (A) Dendritic tributary channel sand in a broad expanse of flood-plain silt and clay; (B) transitional slightly meandering narrow channel sand in less extensive flood-plain silt and clay; (C) highly meandering channel sand of a broad meander belt with local clay plugs and remnants of flood-plain silt and clay; (D) distributary channel sand in extensive marsh and swamp silt and clay (Delta Plain); (E) delta-front sand arc, including distributary-mouth bars, delta-front slope sheets, distal delta-front interbeds, and marginal delta-front remnants; (F) strandplain sheet sand stringers, elongate parallel to shoreline of deposition; flanked landward by lagoonal or coastal-marsh silt, clay, shell, and shell derivatives; gulfward, by marine clay; (G) barrier-bar stacked sand beds, elongate parallel to shoreline, grading abruptly landward into lagoonal silt and sideritic clay, and interfingering gulfward with marine clay.

Figure 11 is a diagrammatic dip profile through a ladle-shaped deltaic "pod" from the landward Mount Pleasant Fluvial System through the gulfward Rockdale Delta System identifying five of the seven sediment facies listed above. In plan and profile, the geometric shape of each sediment facies 


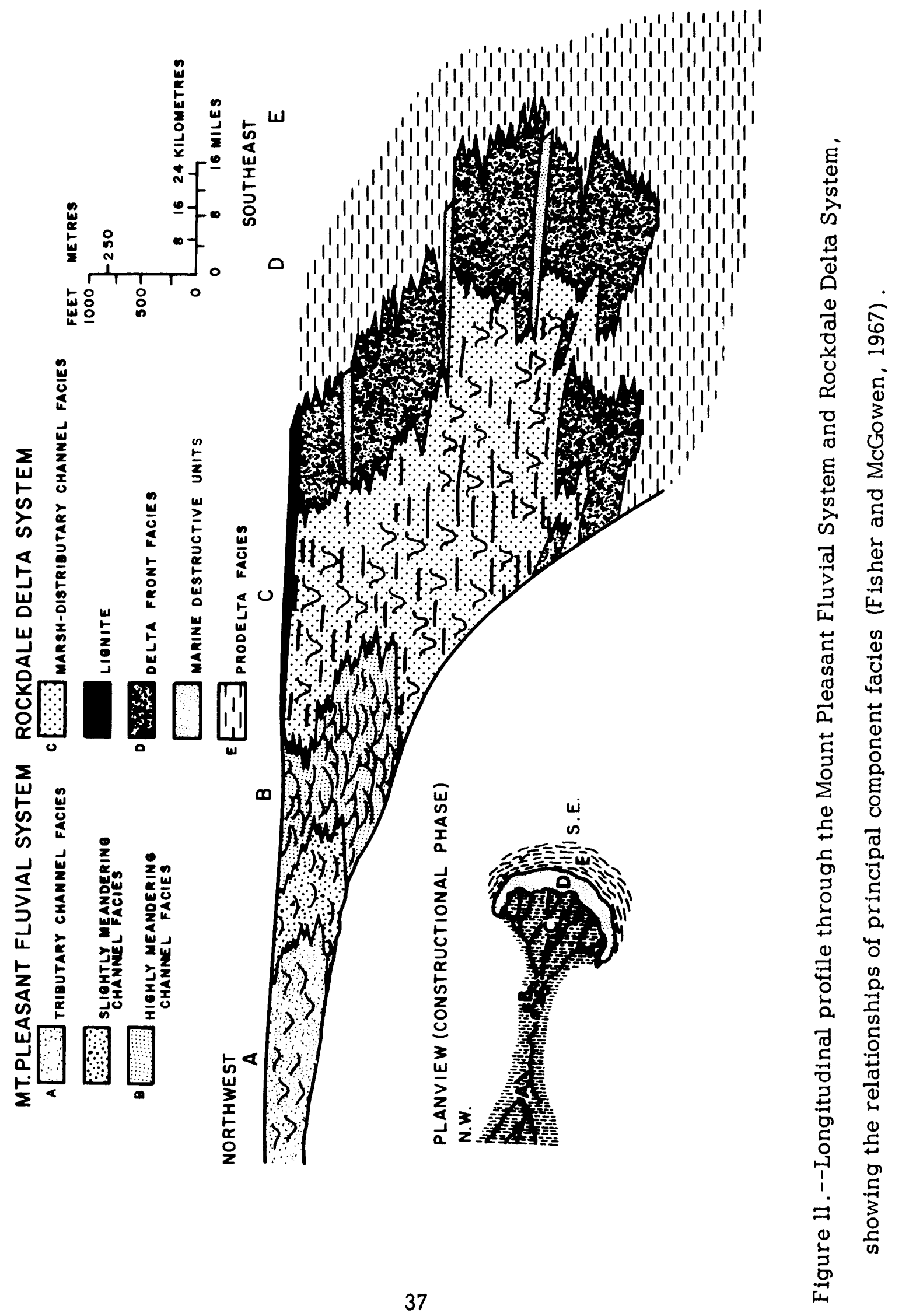


has its own diagnostic features. These provide a useful basis for interpolating sediment-distribution patterns in the subsurface according to type and for mapping depositional systems .

Lower Wilcox.--The first of several major cycles of noncarbonate clastic sedimentation in the northern Gulf basin resulted in the advance of a great delta complex across the area of the upper Texas Gulf coastal plain. These delta systems and their associated barrier bar, strandplain, and baylagoon deposits form perhaps three-fourths of the mass of the lower Wilcox. Where the full thickness can be mapped at its landward margin, it is about $1,000 \mathrm{ft}(305 \mathrm{~m})$ thick in northwestern Gonzales County; about 1,600 ft $(490 \mathrm{~m})$ thick in southeastern Burleson County some $90 \mathrm{mi}(145 \mathrm{~km})$ northeastward; and about 2,100 ft (640 m) thick in western Angelina County, $120 \mathrm{mi}(193 \mathrm{~km})$ farther to the northeast. Close to the outcrop in Zavala County near the Rio Grande, the lower Wilcox is less than $100 \mathrm{ft}(31 \mathrm{~m})$ thick.

All or parts of seven regional depositional systems have been identified and mapped in the lower Wilcox of Texas (Fisher and McGowen, 1967, p. 105-125; 1969, p. 30-54). These are shown in figure 12 and on plate 1 ; subsurface features of these systems are shown on plates 2-6. Well control used in mapping these systems and cumulative thickness of all sand beds in the lower Wilcox are shown in figure 13.

The most inland sand dispersal system is named the Mount Pleasant Fluvial System (Fisher and McGowen, 1969, p. 31). It is made up of sinuous river-channel deposits with a dendritic pattern landward. The channel sands are enveloped in flood-plain deposits of silt and clay. This channel- 


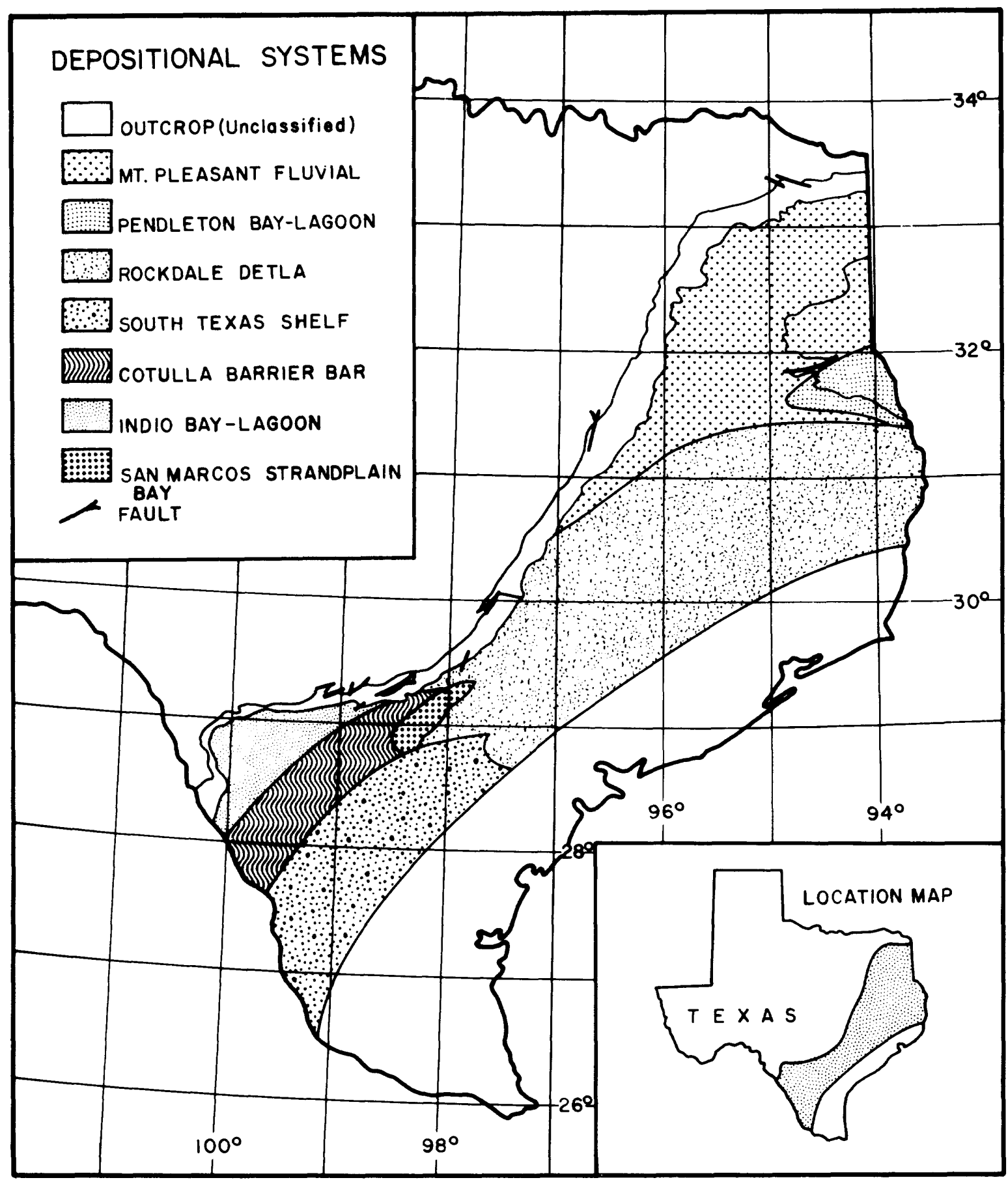

Figure 12.--Seven principal depositional systems of the lower Wilcox in Texas (Fisher and McGowen, 1967). 


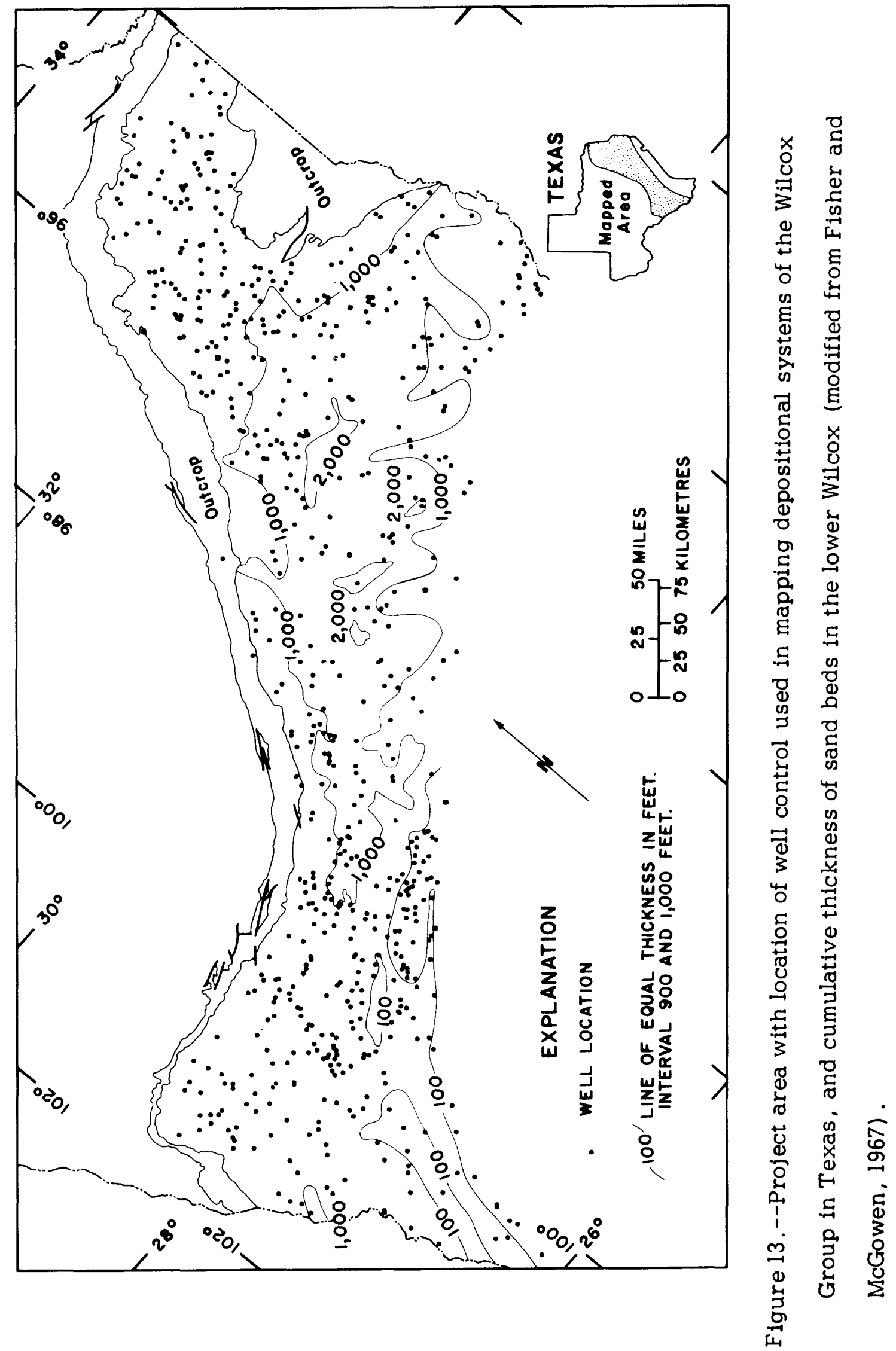


flood-plain facies grades into a narrow-to-broad meander belt and backswamp facies southward; and farther gulfward, the system fans out to become a major delta system.

Gulfward from the Mount Pleasant Fluvial System are three contemporaneous depositional systems, derived directly or indirectly from sediments transported through the Mount Pleasant Fluvial System. Largest and hydrologically the most important sedimentary element of the lower Wilcox is the Rockdale Delta System (fig. 12 and pl. 1), flanked laterally by bay-lagoon deposits. Lying between the eastward encircling Rockdale deita and the southern margin of the Sabine uplift is the remnants of the Pendleton BayLagoon System, now largely eroded. Lying between the westward encircling Rockdale delta and the San Marcos arch is the San Marcos StrandplainBay System. The strandplain deposits of the San Marcos System are extensive and contain an appreciable amount of sand. The San Marcos Strandplain and Cotulla Barrier Bar Systems to the southwest form a broad, continuous sand-bed pattern in good trend alignment with "pods" of maximum cumulative sand-bed thickness in the Rockdale (fig. 12). These were formed by sediments carried by longshore currents from the Rockdale Delta System. Inland from the Cotulla Barrier-Bar System is the Indio Bay-Lagoon System. Formed in a sediment-starved environment, it was preserved from later erosion by downwarp of the Rio Grande embayment. Gulfward is the South Texas Shelf System, mainly clay and silt.

Mount Pleasant Fluvial System.--Eroded remnants of a major fluvial system are preserved in the downwarp of the East Texas basin and its gulfward extension, the Houston embayment. Named the Mount Pleasant Fluvial System by Fisher and McGowen (1967, p. 107), it includes (fig. 14): 


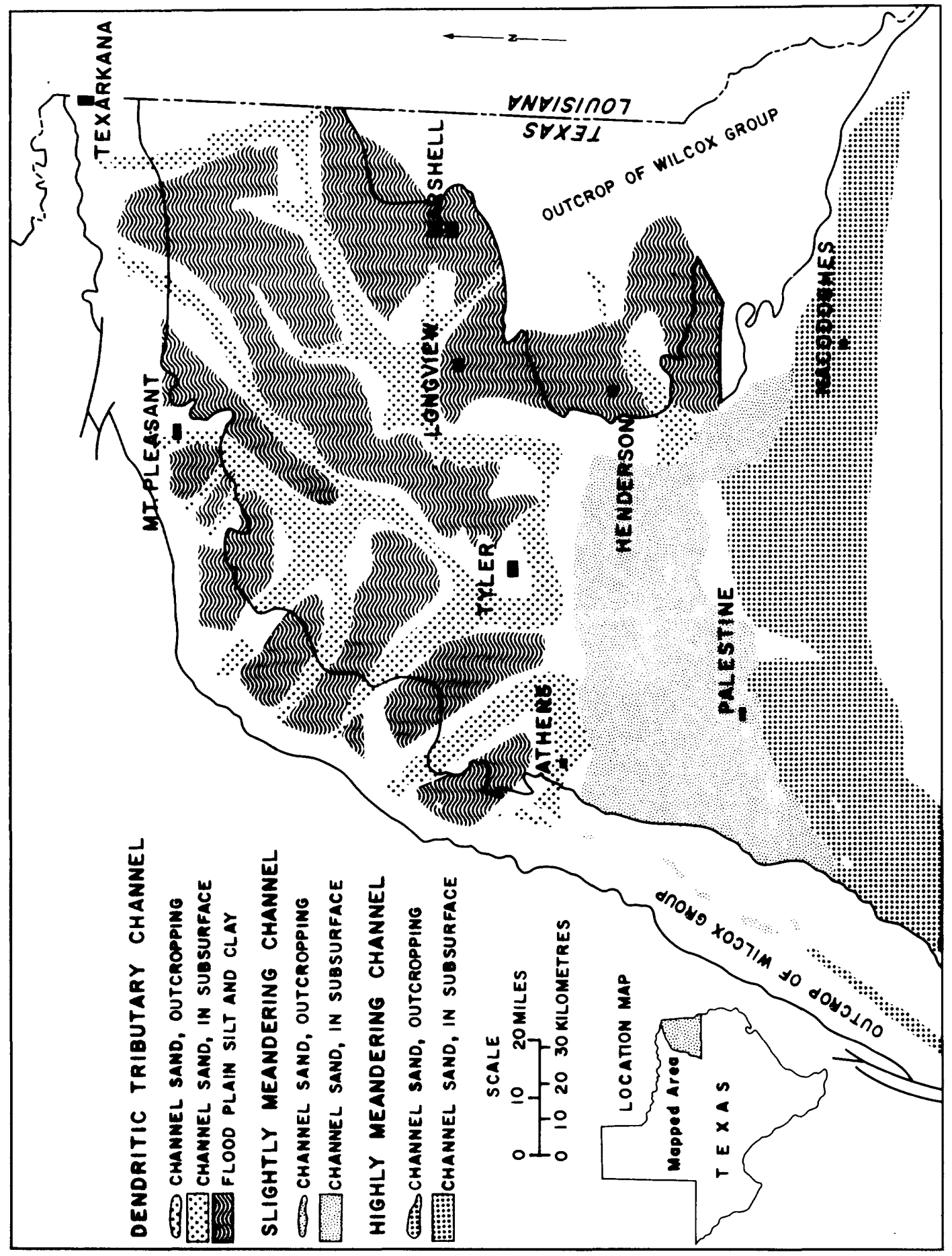

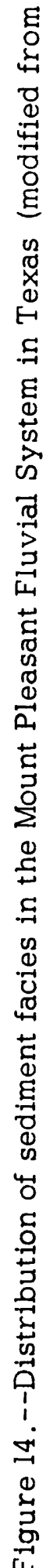


(1) A dendritic tributary channel facies, largely missing; (2) a slightly meandering channel facies, also much eroded; and (3) a highly meandering channel facies, largely preserved. A distinctive feature of each of these facles is the relative abundance of sand and silt or clay. Channel deposits are essentially sand; flood-plain deposits are mainly clay and silt. Volumetric ratios of channel to flood-plain deposits are, in order listed above: (1) 1 to 2, (2) 2 to 1.5 , and (3) 9 to 1 .

Thickness of sand beds in the dendritic tributary channel facies ranges from about 3 to $80 \mathrm{ft}$ ( 1 to $25 \mathrm{~m}$ ); texture ranges from fine- to mediumgrained; deposits formed by the sand beds are flat-topped and convex downward into an envelope of silt and clay (fig. 10). Thickness of the tributary channel facies ranges from about 300 to $800 \mathrm{ft}$ ( 90 to $240 \mathrm{~m}$ ) in the mapped area, generally increasing both towards the axis of the east Texas basin and gulfward. This facies grades through a transitional facies of slightly meandering channels with almost equal amounts of sand and clay or silt to highly meandering facies with about 90 percent of the total thickness made up of channel deposits, mainly sand. Southward from the latitude of Palestine (fig. 14), this system is blanketed by deposits of the upper Wilcox. Cumulative thickness of sand beds increases rapidly southward to $1,000 \mathrm{ft}(305 \mathrm{~m})$ and more.

Subsurface features of the Mount Pleasant Fluvial System along the lines of two geologic cross sections, $C-C^{\prime}$ and $D-D^{\prime}$, are shown on plates 4 and 5 . (For location of sections, see fig. 5.) Along section C-C', thickness of the system increases from about $1,200 \mathrm{ft}(370 \mathrm{~m})$ in southeastern Milam County to about $1,600 \mathrm{ft}(490 \mathrm{~m})$ in northwestern Burleson County, where 
the belt it forms is only $20 \mathrm{mi}(32 \mathrm{~km})$ wide. Here, the lower $500 \mathrm{ft}(150 \mathrm{~m})$ is mainly lagoonal mud, but the upper part of the system includes massive sand beds 400 to $500 \mathrm{ft}$ ( 120 to $150 \mathrm{~m}$ ) thick. The cumulative thickness of sand is as much as $1,000 \mathrm{ft}(305 \mathrm{~m})$ or more. To the northeast along the line of section $D-D^{\prime}$, the entire system is preserved for a distance of about $120 \mathrm{mi}(193 \mathrm{~km})$. Its thickness ranges from about $500 \mathrm{ft}(150 \mathrm{~m})$ in Upshur County to about $2,000 \mathrm{ft}(610 \mathrm{~m})$ in southern Nacogdoches County; at its gulfward margin, half its thickness is of sand beds .

In summary, the Mount Pleasant Fluvial System is characterized by sand-bed sequences having great areal continuity in some direction because of their fluvial origin. These sand beds, generally narrow and sinuous to the north, are 20 to $100 \mathrm{ft}(6$ to $30 \mathrm{~m})$ or more in thickness . Southward, they broaden, become massive, and dominate the lithology of the system.

Rockdale Delta System.--Long recognized as the principal depositional system of the lower Wilcox in Texas (Echols and Malkin, 1948, p. 11-33), the Rockdale Delta System covers some $24,000 \mathrm{mi}^{2}\left(62,160 \mathrm{~km}^{2}\right)$, including 16 major delta lobes. It was the principal source of sediments in associated strandplain, barrier-bar, bay-lagoon, and shelf systems of the lower Wilcox. Average thickness of the system is about $4,000 \mathrm{ft}(1,220 \mathrm{~m})$, and maximum thickness is at least $8,000 \mathrm{ft}(2,438 \mathrm{~m})$ along the gulfward margin (Fisher, 1969a, p. 242). The system includes four regional sediment facies: (1) Delta Plain, (2) Delta Front, (3) Prodelta, and (4) Subembayment (pls. 1-6). The Delta Plain facies has been described in detail by Fisher as follows (1969a, p. 243): "Characteristic features of the delta plain facies 
(distributary channel-marsh-swamp facies of Fisher and McGowen, 1967) are elongate sand bodies that show a distributive pattern in plan and symmetry in cross section, alternating with lignite-bearing interdistributary muds and thin, crevasse-splay and levee sands and silts. Channel sands are commonly up to 200 feet [61 m] thick owing to differential subsidence in thick delta plain muds and multiple occupation of distributary courses, and generally show a sharp basal and upper contact with muds."

Fisher and McGowen also state $(1967, \mathrm{p} .112)$ that: "Muds and silts, making up about 60 percent of this facies, apparently accumulated as subaerial levee, crevasse splay, lacustrine, and flood basin interdistributary deposits .

"Two kinds of lignites occur within the distributary channel-marsh facies, both distinct from the elongate lignite deposits of the fluvial system. One type, which is tabular in shape but only local in extent, probably represents peat accumulation in local interdistributary depressions similar to origin of interdistributary peat in the Mississippi Delta System as discussed by Fisk (1960). A second type is also tabular in shape but much more areally extensive; this type probably developed as a regional, landward facies of marine, delta destruction."

The Delta Plain facies makes up more than half the area of the Rockdale Delta System (pl. 1) and includes the bulk of its sandy deposits. Throughout most of its extent, the cumulative thickness of the sand beds exceeds $1,400 \mathrm{ft}(430 \mathrm{~m})$. In four depocenters, cumulative thickness of sand beds exceeds $2,000 \mathrm{ft}(610 \mathrm{~m})$ : (1) An elongate pod some $50 \mathrm{ml}(81 \mathrm{~km})$ long and $6 \mathrm{mi}(10 \mathrm{~km})$ wide, its long axis roughly parallel to the strike of the formation, 
in northern Grimes, southeastern Madison, and northern Walker Counties; (2) a flattened ellipse some $30 \mathrm{mi}(48 \mathrm{~km})$ long and $8 \mathrm{mi}(13 \mathrm{~km})$ wide, the long axis roughly parallel and adjacent to the line of dip section $\mathrm{C}^{-\mathrm{C}^{\prime}}$ (pl. 1) in eastern Washington and northern Waller Counties; (3) a pod having a small diameter of about $7 \mathrm{mi}(11 \mathrm{~km})$ and a long diameter of $12 \mathrm{mi}$ $(19 \mathrm{~km})$, located at the intersection of the boundaries of Austin, Fayette, and Washington Counties; and (4) a strike trending pod, $12 \mathrm{mi}(19 \mathrm{~km})$ long and $4 \mathrm{mi}(6 \mathrm{~km})$ wide in southwest Montgomery County .

Where geologic dip section B-B' (pl. 3) crosses the Guadalupe deltas, thickness and areal continuity of sand beds in the Delta Plain facies is greatest in central and southeastern Gonzales County and in northern DeWitt County. Here, a massive sand section containing about $1,000 \mathrm{ft}$ $(305 \mathrm{~m})$ of sand is present. Along geologic section $\mathrm{C}^{-\mathrm{C}^{\prime}}$ (pl. 4), thickness and areal continuity of sand beds in the Delta Plain facies of the Brazos deltas is greatest in northern Washington and southeastern Burleson Counties--where massive sand beds range from 600 to $900 \mathrm{ft}$ (180 to $275 \mathrm{~m}$ ) in thickness between depths of 3,800 and $6,800 \mathrm{ft}(1,160$ and $2,070 \mathrm{~m})$. Along geologic section $D-D^{\prime}(p l .5)$, cumulative thickness of sand beds of the Delta Plain facies ranges from 1,400 to $1,600 \mathrm{ft}$ ( 430 to $490 \mathrm{~m}$ ), the maximum occurring in Angelina County. In this area, a thin transgressive marine shale about $600 \mathrm{ft}(180 \mathrm{~m})$ below the top of the lower Wilcox separates successive phases of deposition. Individual sand bed thicknesses are generally less than $50 \mathrm{ft}(15 \mathrm{~m})$. Total thickness of the Delta Plain facies of the Rockdale along section $D^{-} D^{\prime}$ ranges from about $2,000 \mathrm{ft}(610 \mathrm{~m})$ landward to about $2,400 \mathrm{ft}(730 \mathrm{~m})$ gulfward, and depth to the upper boundary 
of the system ranges from about $2,000 \mathrm{ft}(610 \mathrm{~m})$ in northern Angelina County to about $6,000 \mathrm{ft}(1,830 \mathrm{~m})$ in east-central Polk County--a distance of about $45 \mathrm{mi}(72 \mathrm{~km})$.

Geologic section E-E' (pl. 6) is a coastwise section that crosses transversely the six main deltaic lobes of the Rockdale and three of the subembayments that separate them (pl. 1). The Guadalupe deltas (fig. 15) consist of two subdeltas, one trending southwestward across western Gonzales County and northeastern Karnes County, and the other trending southward across eastern Gonzales County and northern DeWitt County . The axes of these two subdeltas mark locations of contemporaneous distributary meander belts of a major river system. As shown on section E-E' which follows the axis of the southwestern subdelta and crosses transversely the southeastern one, excellent continuity of sandy deposits occur throughout. Total thickness of the depositional mass varies little for a distance of about $55 \mathrm{ml}(89 \mathrm{~km})$. Total thickness of the system is about $1,800 \mathrm{ft}(550 \mathrm{~m})$. The basal $400 \mathrm{ft}(120 \mathrm{~m})$ of the southwestern subdelta is thin-bedded sand and clay which underlies a transgressive marine shale. In the eastern subdelta, a transgressive marine shale is about $800 \mathrm{ft}(245 \mathrm{~m})$ above the base. Sand beds below this marine shale are thick and areally extensive in the eastern subdelta, while above, massive sand beds terminate abruptly at the margin of the Yoakum Channel, a large erosional channel cut into the lower Wilcox largely filled with middle Wilcox shale. Sand beds below the transgressive marine shale thicken eastward. Some $15 \mathrm{mi}$ $(24 \mathrm{~km})$ to the east, they grade laterally into Delta Front sand in Lavaca County . 


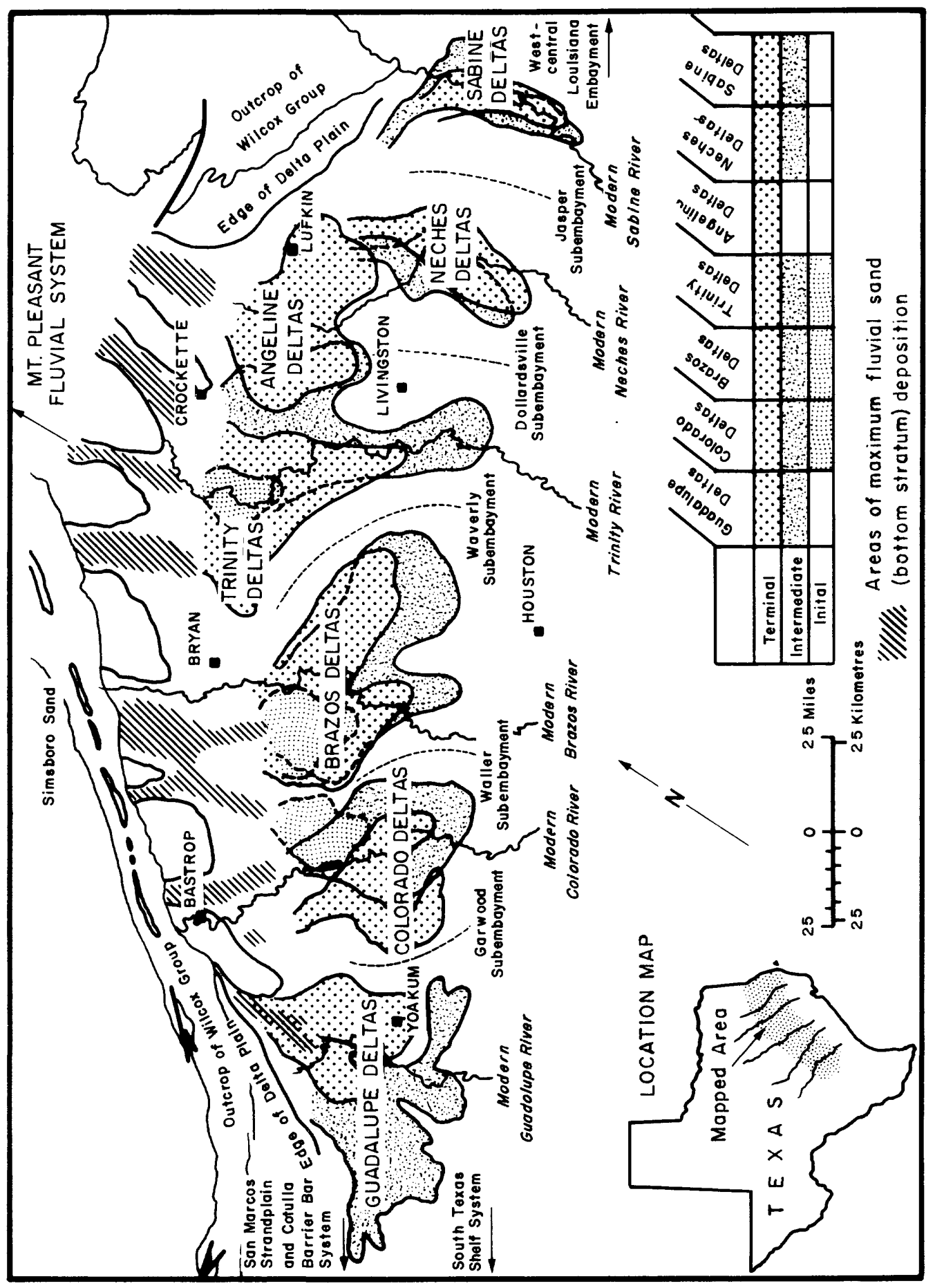

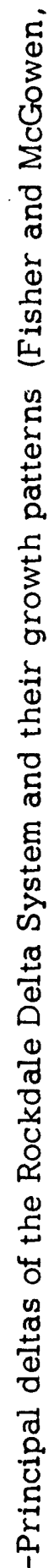

ลิ 
The second major deltaic lobe (the Colorado deltas) of the Rockdale System is crossed transversely by section E-E' from central Colorado County to northeastern Austin County. Along the line of section, these deltas are about $30 \mathrm{mi}(48 \mathrm{~km})$ wide. Their total thickness ranges from 2, 400 to 2,800 $\mathrm{ft}(730$ to $850 \mathrm{~m})$, increasing northeastward. As in the Guadalupe deltas, the deposits are divided into upper and lower units by a transgressive marine shale bed. The upper unit is almost all sand beds with single beds commonly $100 \mathrm{ft}(31 \mathrm{~m})$ or more in thickness. The lower unit is about $1,700 \mathrm{ft}(520 \mathrm{~m})$ thick; massive sand beds occur immediately below the thin marine shale and downwards for about $1,000 \mathrm{ft}(305 \mathrm{~m})$. The basal 500 to $700 \mathrm{ft}$ ( 150 to $215 \mathrm{~m}$ ) of the Delta Plain facies in this lobe grade downward from sandy to shaly deposits. To the southwest the Delta Plain facles grades abruptly into Delta Front deposits; to the northeast, landward of a narrow marine subembayment re-entrant (pl. 1), it merges with Delta Plain sediments of the Brazos deltas. Along the axis of this lobe, in a southeastward-trending belt 10 to $12 \mathrm{mi}$ ( 16 to $19 \mathrm{~km}$ ) wide and some $40 \mathrm{mi}(64 \mathrm{~km})$ long, the cumulative thickness of sand beds exceeds $1,800 \mathrm{ft}(550 \mathrm{~m})$.

The Brazos deltas are the largest delta complex of the Rockdale System; this complex is centered in Grimes County. It has two major sand depocenters. Along section E-E' the Delta Plain factes is some $55 \mathrm{ml}(89 \mathrm{~km})$ wide. Total thickness ranges from 2,800 to about $4,000 \mathrm{ft}$ ( 855 to 1,220 m). Cumulative thickness of the sand beds ranges from about 1,000 ft (305 $\mathrm{m})$ along the southwest margin of the lobe to about 2,200 $\mathrm{ft}(670 \mathrm{~m})$ along its axis in eastern Washington County and northwestern Waller County. 
Individual beds of sand commonly range from 50 to $150 \mathrm{ft}$ ( 15 to $45 \mathrm{~m}$ ) in thickness, and massive sand-bed sequences range from 200 to $400 \mathrm{ft}$ (60 to $120 \mathrm{~m}$ ) in thickness along the major axis of the lobe. Along section $\mathrm{E}-\mathrm{E}^{\prime}$ the base of the Delta Plain deposits is between 10,800 and $12,800 \mathrm{ft} \quad(3,290$ and $3,900 \mathrm{~m}$ ) below sea level overlying Delta Front sand interbedded with prodelta mud. Northeastward the Delta Plain deposits grade into Delta Front sand. Maximum cumulative thickness of sand is about 2,400 ft (730 $m)$. The gulfward sand depocenter in this lobe occurs in south-central Montgomery County, marking the location of a major distributary.

To the northeast of the lobate Brazos deltas are three elongate delta complexes: The Trinity deltas, Neches deltas, and Sabine deltas of the Rockdale System. A deep subembayment 25 to $30 \mathrm{mi}(40$ to $48 \mathrm{~km}$ ) in length, trending almost due southeastward, separates the Trinity deltas from the Brazos deltas. The axis of the Trinity deltas trends southeastward through San Jacinto County; this lobe is about $44 \mathrm{mi}(70 \mathrm{~km})$ wide where it is crossed by section $E-E^{\prime}$. Here, the maximum thickness of the Delta Plain deposits is about $3,200 \mathrm{ft}(975 \mathrm{~m})$, and the maximum cumulative thickness of sand beds is about $1,600 \mathrm{ft}(488 \mathrm{~m})$ in a belt about $3 \mathrm{mi}(5 \mathrm{~km})$ wide and $15 \mathrm{mi}$ $(24 \mathrm{~km})$ long. The Delta Plain deposits are bounded by Delta Front sediments to the southwest and northeast. Although mainly composed of sandy deposits, the Trinity deltas include few sand beds greater than $100 \mathrm{ft}(30 \mathrm{~m})$ in thickness, and most of the sand beds are less than $60 \mathrm{ft}(20 \mathrm{~m})$ thick.

Two lesser deltaic sequences, the Neches and Sabine, trend southward directly gulfward from the Pendleton Bay-Lagoon System marking the easternmost extent of the Rockdale Delta System. The Neches deltas are 
only about $3 \mathrm{ml}(5 \mathrm{~km})$ wide and $12 \mathrm{ml}(19 \mathrm{~km})$ long. They Include a narrow belt along their axis where the cumulative thickness of sand beds is about $1,600 \mathrm{ft}(490 \mathrm{~m})--1 \mathrm{n}$ northeastern Tyler County Section E-E' almost parallels the axis of the Neches deltas for about $5 \mathrm{ml}(8 \mathrm{~km})$, and the logs of wells show few sand beds more than $50 \mathrm{ft}(15 \mathrm{~m})$ in thickness. The Sabine deltas are the easternmost deltas of the Rockdale System. They underlle southcentral Sabine County and northwestern Newton County. The cumulative thickness of their sand beds ranges from 1,000 to $1,400 \mathrm{ft}$ ( 305 to $430 \mathrm{~m}$ ) but is generally about $1,200 \mathrm{ft}(365 \mathrm{~m})$ along an axial belt $3 \mathrm{mi}(5 \mathrm{~km})$ wide and $10 \mathrm{mi}(16 \mathrm{~km})$ long. This belt trends southeastward through Burkeville. These two easternmost delta complexes of the Rockdale Delta System lie gulfward from the Pendleton Bay-Lagoon System, reflecting conditions comparable to the Holocene Saint Bernard delta of the Mississippi River.

Flanking all of the gulfward margin of the Rockdale Delta Plain-except at the landward end of the Waller, Waverly, and Jasper subembayments (fig. 16) is the Delta Front factes. Fisher and McGowan (1967, p. 112) describe this facles as follows: "Downdip the distributary channel-marshswamp facles changes abruptly to a thick sand facies in which lignites are absent and mud content is low ... [see flg. 11]. These sands are mostly fine grained, generally much better sorted than fluvial and distributary channel sands. Commonly, they show thin, multidirectional, ripple cross laminae and other current features. Plant and detrital lignite fragments occur locally. Individual sand units are generally 200 or more feet [61 or more m] thick; in plan, external geometry is lobate or lunate. They are interpreted as distrtbutary mouth bars representing delta front 
DEPOSITIONAL FACIES

HIGH - CONSTRUCTIVE LOBATE DELTA

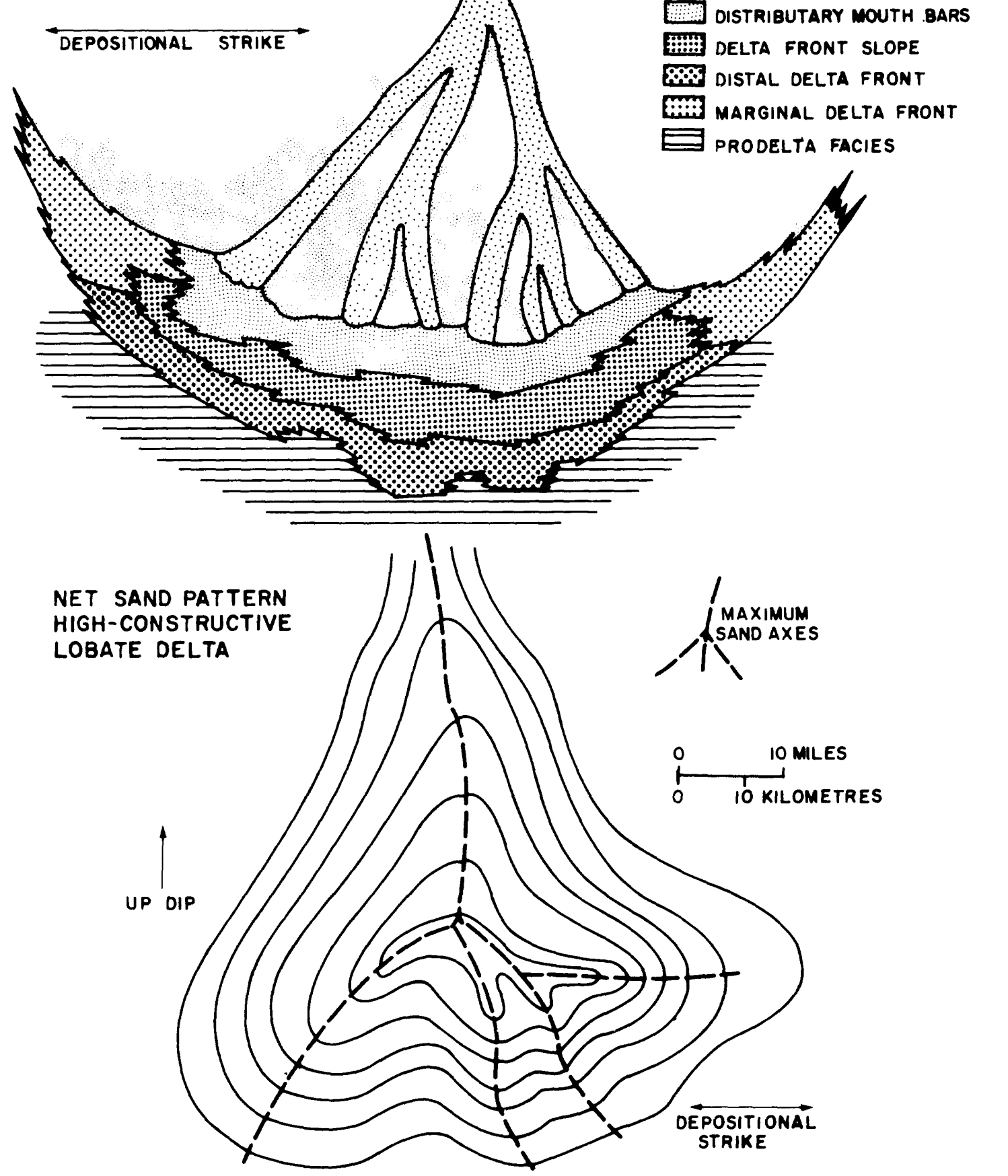

FLUVIAL CHANNEL FACIES

DELTA PLAIN FACIES

DISTRIBUTARY CHANNEL FACIES INTERDISTRIBUTARY-CREVASSE DELTA FRONT FACIES OISTRIBUTARY MOUTH BARS DELTA FRONT SLOPE DISTAL DELTA FRONT PRODELTA FACIES MARGINAL DELTA FRONT

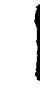

$$
\text { । }
$$


deposition. The high percentage of sand in this facies resulted from deposition of bedload of delta plain distributary channels debouching into relatively quite marine-water reservoirs; the muds were carried in suspension farther seaward, accumulating as prodelta deposits. Relative cleanness, good sorting, and multidirectional current features indicate winnowing and reworking of sands in this environment by both channel and open-water currents under shoal conditions existing in the delta front environment. Redistribution of delta front sands and lateral coalescing of constructive delta front deposits result in a more or less continuous, arcuate delta front sand facies for most of the Rockdale deltas." Fisher (1969a, p. 246) adds that: "Several depositional units are recognized in the delta front sand facies which accumulated seaward of the delta plain ... [see figs. 9 and 16]. As these sands are the principal oil and gas reservoirs in high-constructive deltas, recognition of specific units is critical in delineating and predicting reservoir characteristics. Immediately at the terminus of distributary channels and forming a prominent sand unit in the delta front facies is a characteristic progradational sequence, marked by upward coarsening and increasing sand content. These units accumulated as distributary mouth bars and on subsurface logs are marked by an inverted Christmas tree S. P. profile with the lower part of the sequence consisting of more distal sands and silts of the delta front interbedded with prodelta muds, grading upward to thicker sands of the upper part of the channel-mouth bar . . . [see fig. 8]. Seaward or downdip of the distributary mouth bar sequence and what are here designated as delta front slope and distal delta front units, sands decrease in amount and thickness and generally become muddy. Characteristic sand pattern shows a more or less symmetrical S. P. deflection 
. . [see figs. 9 and 16] . Downdip and seaward of the delta front facies, sands are gradually lost and the sequence consists almost entirely of prodelta muds . . . [see figs. 9 and 16].

"In the lobate type of high-constructive delta there is some marine reworking of delta front sands, producing a coalesced, continuous lobate sand fringe. Along relatively narrow lateral margins of the delta front accumulation of sand is chiefly by marine processes . . . [see fig. 16] . A typical sequence in the marginal delta front shows several sand units with sharp basal and upper reflections on the S. P. profile . . . [see fig. 9] . Interbedded with marginal delta front sands are shelf, lagoonal, and marsh muds and commonly a few thin lignites."

The Delta Front facies is characterized by the great areal continuity and uniform texture of its relatively thin blanket sand beds, as well as the considerable thickness of the stacked sand-bed sequences immediately gulfward from the Delta Plain deposits. The zones of transition from Delta Plain to Delta Front, and to Prodelta deposits, are generally gradational. Boundaries shown on plate 1 are approximate and could, in some places, be shifted a few miles (kilometres) without serious argument. This is particularly true for the Delta Plain-Delta Front facies boundary, for example, between wells 8 and 9 , cross section $B-B^{\prime}(p l .3)$.

In southern DeWitt and Victoria Counties, the Delta Front facies as mapped is primarily silty clay, with thin sand beds zoned at middle depth in the mass. The total thickness of the Delta Front deposits in this area is about $2,200 \mathrm{ft}(670 \mathrm{~m})$, of which sand beds comprise more than half at the landward margin. Gulfward, cumulative sand-bed thickness decreases at a rate of about $100 \mathrm{ft} / \mathrm{mi}(19 \mathrm{~m} / \mathrm{km})$ along this section. The 
total sand thickness is less than $100 \mathrm{ft}(31 \mathrm{~m})$ at the DeWitt-Victoria County boundary .

Along section $C-C^{\prime}$ (pl. 4), which like $B-B^{\prime}$ is a dip section parallelling the axis of a deltaic lobe, the total thickness of the Delta Front deposits is about $3,000 \mathrm{ft}(914 \mathrm{~m})$. In northwestern Harris County, the cumulative thickness of sand beds decreases from about $1,500 \mathrm{ft}(460 \mathrm{~m})$ at the landward facies boundary to about $400 \mathrm{ft}(120 \mathrm{~m})$ at a point $12 \mathrm{mi}(19 \mathrm{~km})$ gulfward; here, too, the cumulative thickness of sand beds decreases gulfward at a rate of about $100 \mathrm{ft} / \mathrm{mi}(19 \mathrm{~m} / \mathrm{km})$.

Section D-D' (pl. 5) crosses the Delta Front facies at the landward end of the Dollarsville subembayment in east-central Polk County. There, both the ratio of the cumulative thickness of sand beds to the total thickness of the deposits and the rate of decrease of cumulative sand-bed thickness gulfward differ somewhat from those cited for sections $B-B^{\prime}$ and $C-C^{\prime}$. The total thickness of the Delta Front deposits is about $3,200 \mathrm{ft}(975 \mathrm{~m})$. Cumulative thickness of sand beds is about $1,200 \mathrm{ft}(365 \mathrm{~m})$ near the landward margin of the deposits, with a rate of decrease gulfward less than $75 \mathrm{ft} / \mathrm{mi}$ $(14 \mathrm{~m} / \mathrm{km})$.

Along the coastwise section, E-E' (pl. 6), deposits of Delta Front facies are crossed in eight places, generally at oblique angles to the cumulative sand-bed thickness isopleths. The southwesternmost transverse, along the southwest flank of the Guadalupe deltas, in northeastern Karnes County follows the belt of maximum cumulative sand-bed thickness for a distance of about $22 \mathrm{mi}(35 \mathrm{~km})$. Total thickness of the Delta Front deposits is about $1,500 \mathrm{ft}(460 \mathrm{~m})$ for this distance, and cumulative sand-bed thickness ranges 
from 800 to $1,100 \mathrm{ft}(245$ to $335 \mathrm{~m})$. Stacked sand beds about $100 \mathrm{ft}(30 \mathrm{~m})$ in thickness occur in almost unbroken sequences 300 to $400 \mathrm{ft}$ (90 to $120 \mathrm{~m}$ ) thick. Sand-bed thickness decreases with depth below a thin transgressive marine shale that lies about $250 \mathrm{ft}(75 \mathrm{~m})$ above the base of the Delta Front facies.

Where section E-E' crosses Delta Front deposits in Lavaca County on the northeast flank of the Guadalupe deltas, their total thickness increases eastward from about 2,200 to $2,800 \mathrm{ft}(670$ to $855 \mathrm{~m})$. From the central part of the county, the cumulative thickness of sand beds decreases rapidly eastward from about 1,400 to $200 \mathrm{ft}(430$ to $60 \mathrm{~m})$ in a distance of only 8 $\mathrm{mi}(13 \mathrm{~km})$--or at a rate of $150 \mathrm{ft} / \mathrm{mi}(28 \mathrm{~m} / \mathrm{km})$ eastward. In Colorado County, on the southern flank of the Colorado deltas, the total thickness of the deposits is about $2,400 \mathrm{ft}(730 \mathrm{~m})$ along section $E-E^{\prime}$. Here, the cumulative thickness of sand beds decreases southward from 1,400 to 200 ft $(430$ to $60 \mathrm{~m})$ in $14 \mathrm{mi}(23 \mathrm{~km})$, measured normal to the thickness isopleths .

To the northeast along section $E-E^{\prime}$ the total thickness of the Delta Front deposits increases to about $3,600 \mathrm{ft}(1,100 \mathrm{~m})$ on the northern flank of the Brazos deltas in northwestern Montgomery County and southeastern Walker County. The total thickness is generally about $3,000 \mathrm{ft}(914 \mathrm{~m})$ as far northeastward as the Neches deltas in central Tyler County. Eastward it thins to about 2,500 ft $(760 \mathrm{~m})$ at the Sabine River. From Polk County eastward the individual sand beds are generally less than $50 \mathrm{ft}$ $(15 \mathrm{~m})$ thick, but they are evenly distributed with depth forming more than half the thickness of the deposits along the landward margin of the Delta Front facies. 
Regionally, the deposits of this facies are remarkably continuous, in broad arcs flanking the lobes of the Delta Plain. The cumulative thickness of sand beds in the Delta Front facies is greatest where this facies merges with the Delta Plain facies. The cumulative thickness thins rapidly approaching the distal ends of the Delta Fronts. As shown on the geologic sections, cumulative sand-bed thickness can change from 75 to $150 \mathrm{ft} / \mathrm{mi}$ ( 14 to 28 $\mathrm{m} / \mathrm{km})$, in a direction normal to the cumulative thickness contours. In general, however, the thickness of sand beds in the Delta Front facies is greater to the southwest than to the northeast.

Between the eight major lobes of the Rockdale Delta System are seven subembayments (pl. 1), each of which recelved fine-grained sediment at the time of deltation on either flank. Fisher and McGowen (1967, p. 112) describe subembayment sediments in the following terms: "Sequences encountered in areas between principal delta lobes are similar in some respects to the prodelta facies. They consist principally of mud, much of which is laminated as in the prodelta facies. The interdelta facies is thinner than the prodelta facies and in addition contains several thin, burrowed mud units or thin units of fossillferous silts and very fine-grained sands, commonly containing small amounts of glauconite. These thin units accumulated more slowly than the laminated muds and in areas not directly affected by deltation."

Deposits of the interdelta subembayment facies are shown on geologic dip section $D^{-D^{\prime}}$ (pl. 5) and geologic strike section E-E' (pl. 6). The subembayment facles grades landward into Delta Front deposits in all but the Waller, Waverly, and Jasper subembayments of the system. Along 
section $D-D^{\prime}$, subembayment clay and silt deposits are about $3,500 \mathrm{ft}$ $(1,067 \mathrm{~m})$ thick.

Section E-E' crosses Rockdale subembayments in two places, eastern Lavaca County and southeastern Walker County, but no log control defines the deposits in Walker County. In Lavaca County, the subembayment facies boundary is very abrupt southwestward; in less than $4 \mathrm{mi}(6 \mathrm{~km})$, the cumulative thickness of sand increases from about 200 to $1,000 \mathrm{ft}$ (60 to $305 \mathrm{~m}$ ). In eastern Lavaca County, subembayment deposits, mainly silt and clay, grade upward from the base into Delta Front deposits over a distance of about $10 \mathrm{mi}(16 \mathrm{~km})$, and they grade downward from the top into Delta Front deposits over a distance of about $5 \mathrm{mi}(8 \mathrm{~km})$.

In southeastern Walker County, subembayment deposits are about $3,400 \mathrm{ft}(1,040 \mathrm{~m})$ thick in the Waverly subembayment, the largest subembayment of the Rockdale Delta System--about $9 \mathrm{mi}(15 \mathrm{~km})$ wide on section $E-E^{\prime}$, and about $66 \mathrm{mi}(110 \mathrm{~km})$ long. Two major river systems were actively prograding at the same time, one to the northeast and one to the southwest of this subembayment.

Gulfward from the Delta Front deposits, and across the mouths of the subembayments, is a continuous belt of marine clay, the Prodelta facies of the Rockdale Delta System. These deposits are 10,000 to $12,000 \mathrm{ft}(3,048$ to $3,658 \mathrm{~m}$ ) below sea level and thousands of feet (metres) thick. Fisher and McGowen (1967, p. 112) describe the Prodelta sediment facies of the Rockdale as follows: "The farthest downdip sections of lower Wilcox penetrated by wells generally consist of relatively uniform, thick sequences of dark muds . . . [see fig. 10]. These contain moderately large amounts 
of very finely comminuted and disseminated organic matter, show laminations marked commonly by slight textural and color variations, and have a marine fauna exceedingly low in numbers and species diversity. This mud facies interfingers with and grades updip to the delta front sand facies and represents deposition from suspension seaward from the delta front and river mouth as prodelta facies. Thickness and downdip extent of the facies are difficult to determine, primarily because few wells have penetrated significant thickness of the lower Wilcox in these downdip areas. However, the few deep wells drilled indicate that the facies is very thick and probably the thickest facies of the delta system; approximately 4,000 to 5,000 feet $[1,220$ to $1,525 \mathrm{~m}]$ have been recorded in some deep wells."

Two geologic dip sections, $B-B^{\prime}$ and $D-D^{\prime}$, cross Prodelta deposits of the Rockdale. In eastern DeWitt County and the northern half of Victoria County, the top of the Prodelta facies is about $10,000 \mathrm{ft}(3,050 \mathrm{~m})$ below sea level, landward. Gulfward, downward displacement along growth faults results in at least a three- or four-fold thickening of the Rockdale over a distance of about $30 \mathrm{mi}(50 \mathrm{~km})$. The top of the Rockdale is at depths of about $16,000 \mathrm{ft}(4,875 \mathrm{~m})$ in central Victoria County. Much of this depth difference is the result of growth faulting with downward displacement and thickening gulfward.

On geologic dip section $D-D^{\prime}$ the Prodelta facies is shown, although only one well on the line of section penetrates it. Structure maps based on seismic records indicate downward displacement of Prodelta deposits gulfward along several major growth faults with the top of the Rockdale displaced to depths about $15,000 \mathrm{ft}(4,575 \mathrm{~m})$ in south-central Hardin County. 
Fisher and McGowen (1967, p. 116) noted that vertical stacking of individual deltas and persistence of interdelta subembayments within the delta system are striking and significant (fig. 15). They state (1967, p. 113) that: "The initial phase of deltation resulted in three relatively small deltas situated roughly along drainage of the modern Colorado, Brazos, and Trinity Rivers . . . [fig. 15]. These range in area from 200 to 350 square miles [518 to $907 \mathrm{~km}$ ] with thicknesses on the order of 300 to 500 feet $[91$ to $152 \mathrm{~m}]$. A second or intermediate period of delta bullding resulted in the largest, thickest, and most prograded deltas of the system. The larger deltas of this phase, up to 2,000 square miles $\left[5,180 \mathrm{~km}^{2}\right]$ in area, were constructed along the axes of the modern Guadalupe, Colorado, and Brazos Rivers; the smaller deltas, 500 to 700 square miles $[1,295$ to $1,813 \mathrm{~km}^{2}$ ] in area, developed along the axes of the modern Trinity, Sabine, and Neches Rivers. The Brazos and Colorado deltas . . . [see fig. 15] are the thickest, with maximum thickness of 1,500 feet [ $457 \mathrm{~m}]$, exclusive of the prodelta facies. A terminal phase of deltation involved delta construction in all areas of intermediate phase deltation as well as construction of a large delta situated primarily in Angelina, Houston, and Trinity counties (Angelina Delta). These terminal deltas are comparable in size and thickness to the underlying, intermediate phase deltas but do not extend as far down structural dip."

Detailed maps of the cumulative thickness of sand beds in the A-, B-, and $\mathrm{C}$-phase deltas have been prepared by the Texas Bureau of Economic Geology, but they are unpublished. These maps suggest that intensive studies designed to classify and characterize each of the types of deltas in 
the Rockdale Delta System would enable detailed description of the geometry and internal structure of sand-bed systems with respect to geographic location providing definitive information on the texture and homogeneity of the sand.

Pendleton Bay-Lagoon System.--Deposits of this system were formed in a slack-water environment. They were derived mainly from fluvial sediments of the Mount Pleasant System and in part from deltaic sediments of the Rockdale. The area of deposition (pl. 1) lies between the Sabine uplift, a positive region during the early Eocene, and the encircling meander belts and delta plains of major prograding Rockdale systems to the west and south. Beneath the Pendleton system are marine clay deposits of the Midway Group; Immediately above the Pendleton lies the Carrizo Sand of the Cladborne Group. The middle Wilcox shale is absent because the marine transgression did not reach this far inland. Therefore, the uppermost beds in the system are probably early Eocene (upper Wilcox) in age .

Fisher and McGowen (1967, p. 117) describe the Pendleton Bay-Lagoon System as follows: ". . . It is approximately 1,000 feet [305 m] thick in Texas, comparable in thickness to fluvial facies along strike but thicker than updip fluvial facies and thinner than downdip delta facies. The Pendleton System consists chiefly of laminated to locally bioturbated muds with local lenses and beds of very fine to fine-grained, sparingly glauconitic, massive to cross-bedded sands and fine-grained, broken, massive to cross-bedded, lignitic sands. Certain of the muds are gypsiferous; clay-ironstone concretions are common. Lignites are locally common, 
though they are relatively impure, thin, and discontinuous. . . A large part of the facies is contemporaneous with delta facies (Sabine deltas of the Rockdale System) to the west and south, though the upper part of the system is contemporaneous with other Wilcox depositional systems not corisidered here."

No geologic section of this report crosses the Pendleton System. However, its deposits resemble those of the San Marcos Strandplain-Bay System shown on section E-E' (pl. 6), particularly those beneath western Wilson and Atascosa Counties at the southwestern extremity of the system.

San Marcos Strandplain-Bay System.--Lying between the San Marcos arch--a structural and geomorphic high during the early Eocene--and the prograding mass of the Rockdale Delta System, this strandplain-bay system developed in much the same way as the Pendleton Bay-Lagoon System. The sediment facies of the San Marcos and Pendleton Systems are similar; they both were formed contemporaneously with the Mount Pleasant and Rockdale Systems by sediments derived from them. Fisher and McGowen (1967, p. 117) describe the San Marcos Strandplain-Bay System as follows: "The faunal and lithologic composition of the facies is very similar to that of the Pendleton System. A similar origin is suggested, with deposition in embayments and on mudflats along the opposite margins of downslope fluvial facies of the Mt. Pleasant System and delta facies of the Rockdale System. In outcrop, muds of this facies are continuous below the downslope facies of the Mt. Pleasant System (highly meandering channel facies or Simsboro Sand) northward to about midway between the Brazos and Trinity Rivers, where the muds grade to fluvial and delta facies of earliest Rockdale deltation [initial phase]... [see fig. 15]. The northern extent 
of this mud facles includes at least parts of units formally designated the Hooper and Seguin Formations. Southwestward displacement of the facies is contemporaneous with subsequent large scale deltation in the lower Wilcox Rockdale System [intermediate and terminal phases]. . . [fig. 15] .

"Downdip and marginal to the shoal-water deltas of the southwestern part of the Rockdale System (Guadalupe deltas) muds grade to a facies consisting of interbedded sands and muds. Sands are generally fine grained, well sorted, at least sparingly glauconitic, and commonly contain a few detrital shell fragments. They occur as elongate bodies parallel to depositional strike to chiefly tabular or sheet sands. Individual sand and mud units are approximately 50 feet $[15 \mathrm{~m}]$ thick. Muds are similar to those of the updip mud facies but commonly pyritic and slightly gypsiferous. Carbonaceous materials are locally present as thin lignitic stringers. This interbedded sand and mud facies is approximately 1,200 feet [366 m] thick, occurring chiefly in southwestern Gonzales, Wilson, southwestern Karnes, and eastern Atascosa Counties. Composition of the facies and its position marginal to shoal-water deltas of the Rockdale System suggest an origin analogous to the Recent chenier system of southwestern Louisiana. Muds accumulated in low energy environments ranging from mudflat to open bay, contemporaneous with periods of active deltation. During marine destruction of the adjacent sand-rich, shoal-water deltas, sands were redistributed laterally by prevailingly southwestward longshore currents with deposition of the elongate to sheet sands in a strandplain marginal to the delta system. Transgression and regression of relatively thin marine units in this facies were thus related to periods of active deltation and delta 
destruction. Such subsurface sands as the Poth and Bartosch are typical of this facies. In reference to their origin and area of principal occurrence, the updip mud and downdip sand-mud facies developed along the southwestern margin of the Rockdale Delta System are designated the San Marcos StrandplainBay System."

The San Marcos System underlies a tadpole-shaped area about $75 \mathrm{mi}$ $(120 \mathrm{~km})$ long (northeast to southwest) and about $22 \mathrm{mi}(35 \mathrm{~km})$ wide at Its "head". In its widest area, the San Marcos System is crossed diagonally (almost east-west) by section E-E' (pl. 6) from central Atascosa County to southernmost Wilson County. Along this line, the system has a rather uniform thickness of about $1,500 \mathrm{ft}(460 \mathrm{~m})$, of which about half is sand beds. The cumulative thickness of sand beds decreases both northward and southward from the line of section. Individual sand beds to the east are generally thinner. Deposits below an extensive thin marine shale about $400 \mathrm{ft}(120 \mathrm{~m})$ above the base of the San Marcos System are very fine-grained grading downward and westward into shale. Above the marine shale and to the west, the Strandplain-Bay System grades into a regional Barrier Bar System, the Cotulla.

Cotulla Barrier Bar System.--The Cotulla Barrier Bar System was formed by southwestward longshore transport of mud and glauconitic fine-grained, well-sorted sand. It extends from the southwestern margin of the San Marcos Strandplain-Bay System to the Rio Grande in a belt about $120 \mathrm{mi}$ $(193 \mathrm{~km})$ long that ranges in width from about $30 \mathrm{mi}(50 \mathrm{~km})$ at the northeast to about $40 \mathrm{mi}(65 \mathrm{~km})$ along the Mexican Border (pl. 1). This system ranges in thickness from about $800 \mathrm{ft}(240 \mathrm{~m})$ in the northeast to about 
$1,300 \mathrm{ft}(400 \mathrm{~m})$ in the southwest, as shown on section E-E' (pl. 6). Along dip section $A-A^{\prime}$ (pl. 2), the system is about $1,300 \mathrm{ft}(400 \mathrm{~m})$ thick at its gulfward extremity and $1,100 \mathrm{ft}(335 \mathrm{~m})$ thick $30 \mathrm{mi}(48 \mathrm{~km})$ inland. Farther updip, it thins rapidly (pl . 2) wedging out beneath the Indio Bay-Lagoon System.

Fisher and McGowen (1967, p. 117-118) describe the Cotulla BarrierBar System as follows: "Southwestward along depositional strike, sheet and elongate sand bodies of the San Marcos System grade to facies of elongate sand bodies arranged parallel to depositional strike. Sands are generally fine grained, very well sorted and locally glauconitic; internal structures are not known, due to lack of cores. Thickness of individual sand units ranges upward to 100 feet $[31 \mathrm{~m}]$, with aggregate sand thickness of 400 to 1,000 feet [ 122 to $305 \mathrm{~m}$ ] for the facies. Sand 1soliths show an extensive elongate sand unit oriented parallel to depositional strike. This belt of sand trends northeast-southwest and occurs in western Atascosa, southern Frio, northwestern LaSalle, southeastern Dimmit, and northwestern Webb Counties [pl. 1] . .

"In the San Marcos Strandplain System, situated intermediate to the delta and barrier bar systems, the adjacent delta system served not only as a source of sands but also, through periods of actlve and inactive deltation, as a control for the distribution of the sheet sands. Accumulation of sand in the barrier bar system was sufficiently distant from the delta system for it to have had any direct control on sand distribution. The principal distinction in sand accumulation in these two systems is chiefly sheet or tabular sand units in the San Marcos System and elongate sands 
in the Cotulla System. Similar patterns in sand dispersal are shown in the modern and premodern marginal marine sand systems southwest of the Mississippi Delta System. In addition, accumulation of sands in relatively narrow elongate belts in the barrier bar system, as opposed to sheet sand accumulation in the strandplain system, facilitated development of extensive, landward mud facies--the Indio Bay-Lagoon System."

Indio Bay-Lagoon System.--The Indio Bay-Lagoon System is a mass of deposits consisting predominantly of lagoonal mud and is located inland from both the Cotulla Barrier-Bar System and the San Marcos StrandplainBay System. It is a belt about $200 \mathrm{mi}(322 \mathrm{~km}$ ) long and 20 to $40 \mathrm{mi}(32$ to $64 \mathrm{~km}$ ) or more in width (pl. 1). These lagoon-bay mud and sand deposits range in thickness from about $200 \mathrm{ft}(60 \mathrm{~m})$ updip and in outcrop in Zavala County to about $900 \mathrm{ft}(270 \mathrm{~m})$ ir easternmost Guadalupe County (pls. 2 and 3). These deposits have extensive tidal channel and washover fan components along their gulfward margin. The sand beds are generally thin, irregular, and discontinuous. Their cumulative thickness does not exceed $200 \mathrm{ft}(60 \mathrm{~m})$.

South Texas Shelf System.--The South Texas Shelf System is a mudstone facies of great areal extent and appreciable thickness located gulfward from the Cotulla Barrier-Bar System. From its northeastern terminus In Karnes and Goliad Counties to the Rio Grande, a distance of 180 to $200 \mathrm{mi}$ $(290$ to $322 \mathrm{~km})$, this facies extends gulfward at least $50 \mathrm{mi}(80 \mathrm{~km})$ from its landward margin (pl. 1). 
This system occurs, according to Fisher and McGowen (1967, p. 118) "over an area of about 3,000 square miles $\left[7,770 \mathrm{~km}^{2}\right]$ in southwestern Karnes, northern Goliad, northern Bee, north Live Oak, McMullen, northwestern Duval, Webb, Zapata, and western Starr counties." These authors add $(1967$, p. 118-120) that: "It is relatively uniform in thickness throughout much of its extent, ranging from about 1,000 to 1,500 feet [ 300 to $460 \mathrm{~m}$ ], but it thickens northeastward toward the Rockdale Delta System and southward along the Rio Grande. Principal lithologic component is mud; aggregate thickness of sand in the system is generally less than $200 \mathrm{ft}[60 \mathrm{~m}]$ [see pl. 1]. Individual sand units vary in number, commonly 8 to 10 , and in thickness, generally 10 to a maximum of about 100 feet [ 3 to $30 \mathrm{~m}$ ]; average thickness of sand units is about 30 feet $[9 \mathrm{~m}]$. Muds are variable in composition, though generally light to moderate gray to olive or buff, and laminated to extensively burrowed; marine fossils and glauconite pellets are common. Muds are commonly calcareous, though a few are pyritic or carbonaceous. The sands are very fine to fine grained, well sorted to muddy, slightly glauconitic, and commonly contain detrital shell fragments. . .

"Origin of the relatively thin sand units in the South Texas Shelf System is not clear. External geometry of the sand units is not well known, but existing control suggests both laterally persistent sheet sands, more numerous updip toward the Cotulla Barrier-Bar System, and elongate, northeastsouthwest-trending sand bodies. Source of sands was probably the Rockdale Delta System to the northeast like that of updip sand systems, but mode of transport and dispersal of the sands is unknown." 
Throughout most of the $3,000 \mathrm{mi}^{2}\left(7,770 \mathrm{~km}^{2}\right)$ mapped, cumulative thickness of the sand beds is less than $200 \mathrm{ft}(60 \mathrm{~m})$.

Middle Wilcox.--The middle Wilcox separates the great delta-barrier bar-shelf complex of the lower Wilcox from the equally extensive delta complex and associated fluvial and marine systems of the upper Wilcox. It is a regionally transgressive marine clay deposit generally known as the "big shale" among oil geologists of the Gulf basin. The landward extent of this middle Wilcox marine shale is shown on plate 1 and is identified on all of the geologic cross sections (pls. 2-6).

This regional stratigraphic unit is especially important in the Wilcox of Texas because it separates two markedly different delta systems (Fisher, 1971, p. 3): A lower Wilcox "high-constructive delta system," and an upper Wilcox "high-destructive delta system." Both delta systems are primarily sandy deposits, and except for the middle Wilcox marine shale, there would be little restriction of fluid movement between them.

On section $A-A^{\prime}(p l .2)$ this marine shale appears in northern Dimmit County at a depth of $1,400 \mathrm{ft}(427 \mathrm{~m})$; it increases in thickness gulfward to about $400 \mathrm{ft}(120 \mathrm{~m})$ in southeastern Dimmit County; to $600 \mathrm{ft}(180 \mathrm{~m})$ in southeastern LaSalle County; to $1,200 \mathrm{ft}(365 \mathrm{~m})$ in nor theastern Webb County; and to more than $1,800 \mathrm{ft}(550 \mathrm{~m})$ in central Duval County, where it occurs at a depth of more than $10,000 \mathrm{ft}(3,050 \mathrm{~m})$ below sea level.

On section $B-B^{\prime}(p l .3)$, the middle Wilcox marine shale extends inland to northwestern Gonzales County, where it occurs at a depth of about 1,000 $\mathrm{ft}(310 \mathrm{~m})$. It thickens gradually gulfward to about $200 \mathrm{ft}(60 \mathrm{~m})$ in central Gonzales and to about $400 \mathrm{ft}(120 \mathrm{~m})$ in northernmost DeWitt County. Down- 
dip, it thickens greatly across a series of contemporaneous growth faults and is about $2,000 \mathrm{ft}(610 \mathrm{~m})$ thick in Victoria County .

On section $\mathrm{C}^{-\mathrm{C}^{\prime}}(\mathrm{pl} .4)$, the middle Wilcox marine shale appears in northernmost Washington County at a depth of about $5,400 \mathrm{ft}(1,650 \mathrm{~m})$ below sea level, where it is about $150 \mathrm{ft}(50 \mathrm{~m})$ thick. In northern Waller County it is about $600 \mathrm{ft}(180 \mathrm{~m})$ thick--and includes numerous thin sand beds. It thickens gulfward to about $2,000 \mathrm{ft}(610 \mathrm{~m})$ in central Harris County, where the top is about $14,000 \mathrm{ft}(4,300 \mathrm{~m})$ below sea level.

On section $D^{-D^{\prime}}(\mathrm{pl} .5)$, the middle Wilcox marine shale appears in northern Angelina County at a depth of about $2,500 \mathrm{ft}(760 \mathrm{~m})$ below sea level. Here it is about $130 \mathrm{ft}(40 \mathrm{~m})$ thick. In southeasternmost Polk County and northwestern Hardin County, the middle Wilcox shale thickens gulfward across a series of contemporaneous growth faults.

Perhaps the most striking stratigraphlc feature of section E-E' (pl. 6) is the perfect continutty of the middle Wilcox marine shale. Along this generally coastwise section, the middle Wilcox thickens markedly, both southwestward from Polk County and northeastward from Gonzales County . In Lavaca and Colorado Counttes, this is in part due to a gulfward arc in the line or section. Thickness increases from about $250 \mathrm{ft}$ to $800 \mathrm{ft}$ (75 to $244 \mathrm{~m}$ ) from Polk County southwestward to western Austin County and from about $250 \mathrm{ft}$ to $1,700 \mathrm{ft}(75$ to $520 \mathrm{~m}$ ) from Gonzales County northeastward to eastern Lavaca County. The thickness of the middle Wilcox is generally greater than $600 \mathrm{ft}(180 \mathrm{~m})$ gulfward from the areas of maximum cumulative sand thickness of the Rockdale Delta System of the lower Wilcox. This is related to sedimentary tectonfcs during middle Wilcox time. 
In eastern Gonzales and western Lavaca Counties, section E-E' crosses the Yoakum Channel described by Hoyt (1959, p. 41-50). The channel, or canyon (fig. 17), can be traced for more than $50 \mathrm{mi}(80 \mathrm{~km})$ from near its mouth along the southeast line of Lavaca County updip in a north-northwesterly direction to the outcrop of the Wilcox Group in Bastrop County (fig. 17) . The channel is clearly erosional and is filled with middle Wilcox silty shale that contrasts sharply on electric logs with the sandy character of lower Wilcox sediments into which it was cut. Near the town of Yoakum where it reaches maximum development, the canyon was $10 \mathrm{mi}(16 \mathrm{~km})$ wide and $3,000 \mathrm{ft}(915 \mathrm{~m})$ deep. Hoyt $(1959, \mathrm{p} .41)$ attributes development and fill of the canyon to the following factors:

"A. The presence of a major stream.

"B. The great differential in thickness of the Wilcox now known to exist, attaining as much as 8,000 feet $[2,438 \mathrm{~m}]$ at the outer edge of the former continental shelf, which placed an unstable mass of sediments adjacent to deep water and a subsiding sea floor.

"C. Slumps and slides at the mouth of the large stream, triggered in part by the fault action known to have been prevalent during Wilcox time, stoped inland guided by the stream channel and provided a source of turbidity currents powerful enough to cut a gentle gradient to the sea bottom.

"D. An abrupt transgression of the sea led to rapid filling of the gorge and deposition of a thin blanket of shale over a large area outside the channel. This was followed by regression during which the thick and extensive sands of the Carrizo were deposited. These clean massive sands of the uppermost Wilcox entirely obliterated any evidence of the great channel below." 


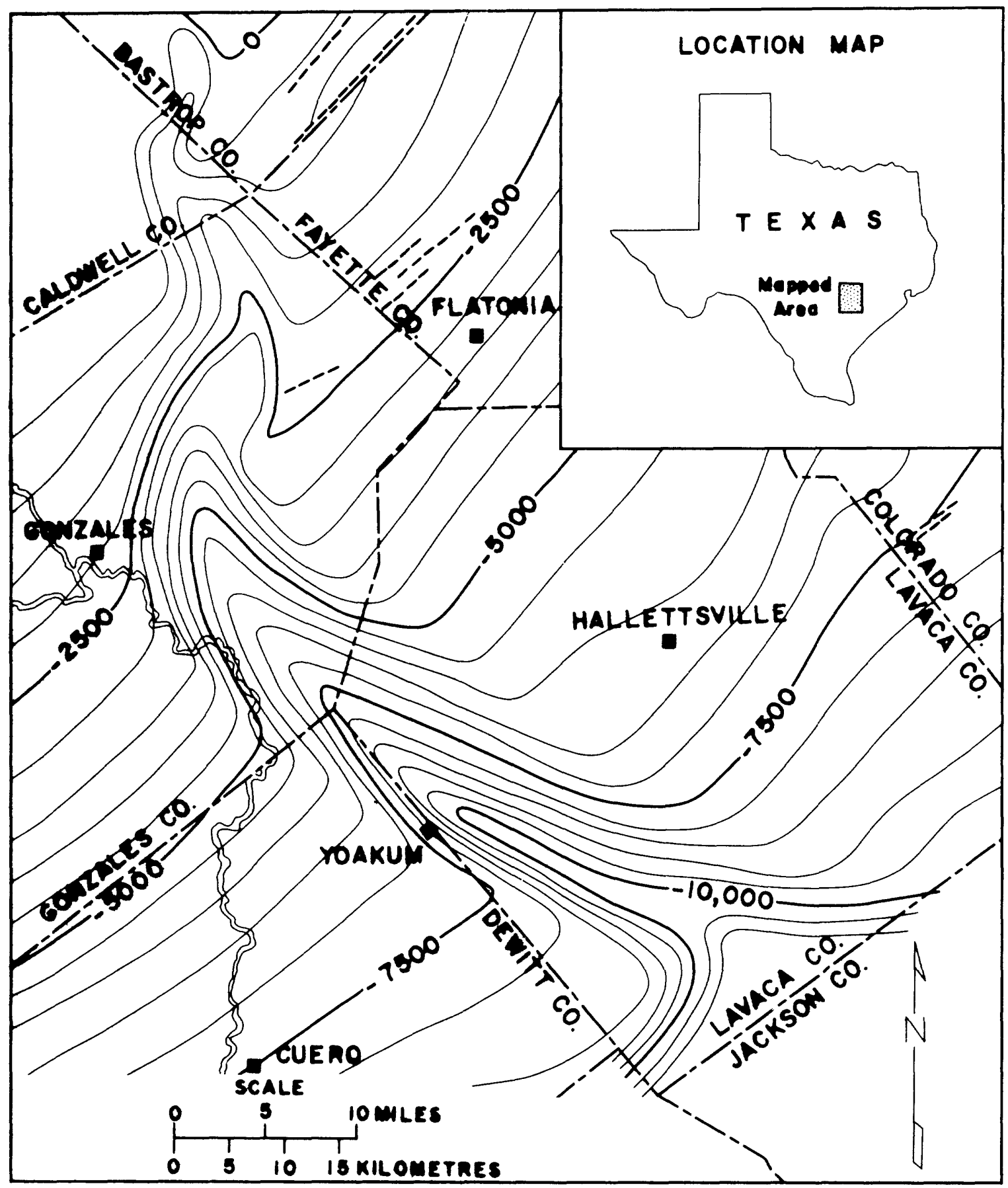

Figure 17.--Regional setting of the Yoakum Channel. Subsea contours on the base of the middle Wilcox shale (contour interval: $500 \mathrm{ft}(152.4 \mathrm{~m})$ ) (Hoyt, 1959) . 
Although the Yoakum Channel is currently a unique phenomenon in the Wilcox, factors requisite for its formation were widespread in the lower Wilcox. However, where the depositional fill of a channel resembles the primary lithology of the eroded formation, it will remain difficult or impossible to detect.

Upper Wilcox.--Another major cycle of deltaic sedimentation in the northern Gulf basin followed the middle Wilcox marine transgression. The upper Wilcox consists of noncarbonate clastic sediments, especially channel and channel mouth bar facies, distributed from the Sabine River to the Rio Grande (pl. 7). The area blanketed by deltaic and delta-derived sediments is about the same as that covered by lower Wilcox deposits, but the volume of fill is less than half as great.

Fisher $(1969 b$, p. 36) describes the upper Wilcox deposits as follows: "Five main facies comprise the major delta units of the Upper Wilcox . . . [see figs. 18 and 19]. These include (1) meander belt channel facies; (2) progradational channel mouth bar facies; (3) coastal barrier or strandplain facies marginal to channel and channel mouth bar facies and also seaward of main sand units; (4) strand-plain-marsh-lagoonal facies developed updip of the coastal barrier facies; and (5) strand-plain-shelf facies developed seaward of the main sand units. Associated facies in addition to those of the updip fluvial system include (1) shelf or prodelta facies and (2) lagoonalfloodbasin facies."

The cumulative thickness of sand beds is shown on plate 7. A series of "pods" of maximum cumulative sand-bed thickness occurs in a belt of coastal-barrier deposits; these "pods" are channel and channel mouth bar 
CONSTITUENT AND BOUNDING FACIES HIGH DESTRUCTIONAL DELTAS

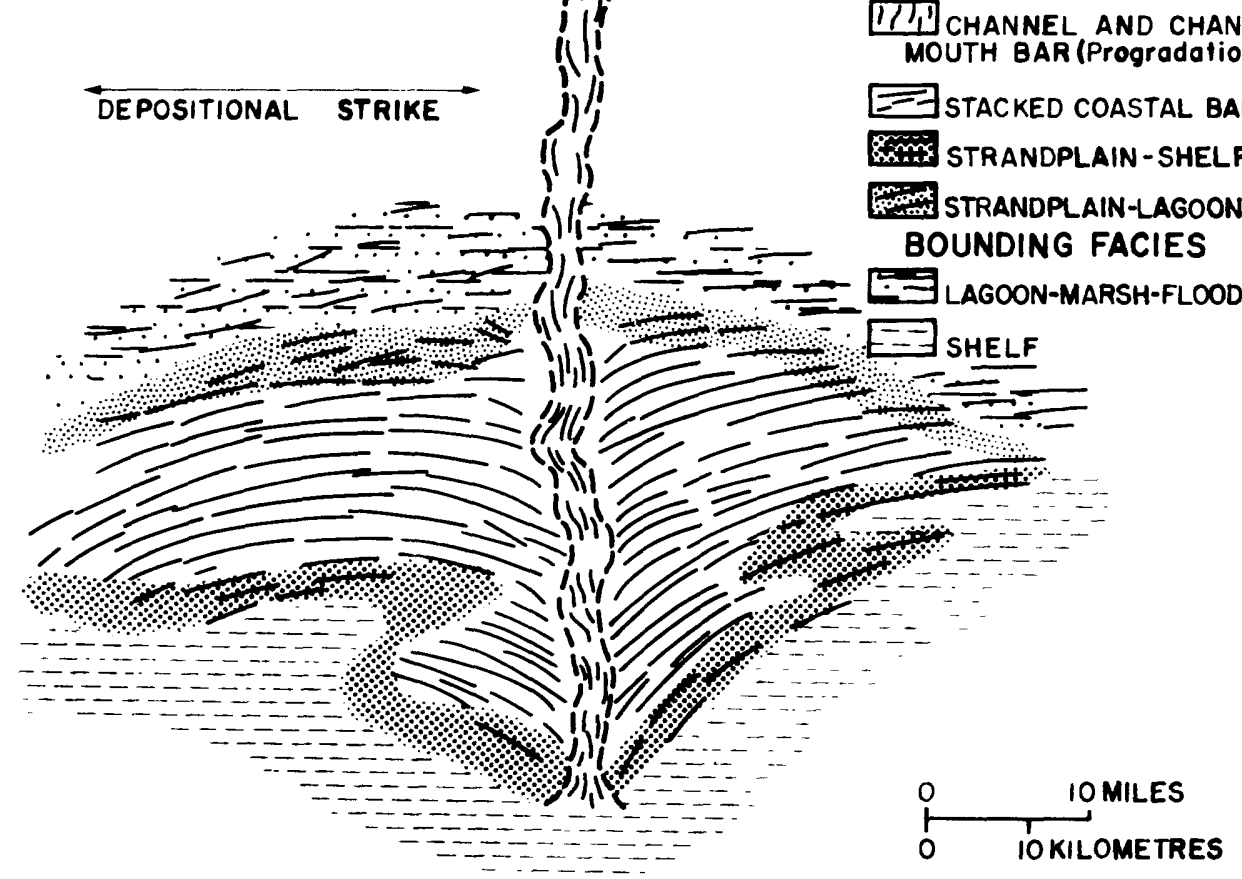

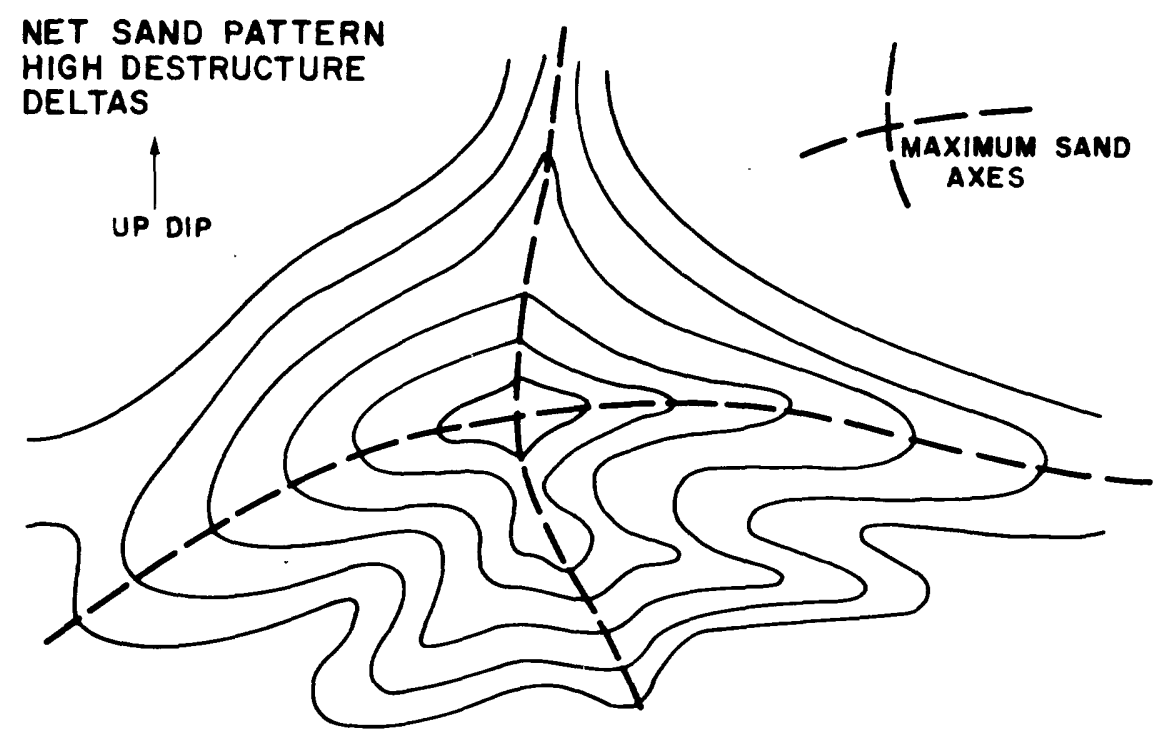

DEPOSITIONAL STRIKE

Figure 18.--Principal facies and sand pattern, high-destructive delta systems, Gulf Coast basin (Fisher, 1969a). 


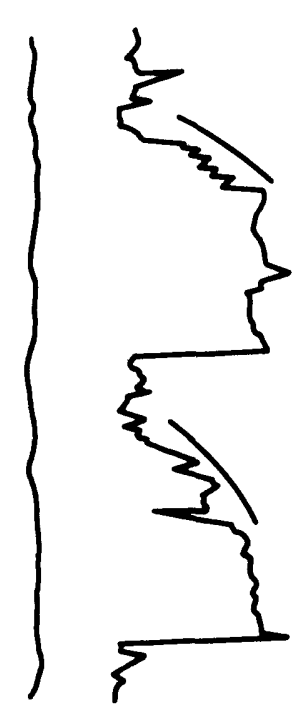

FLUVIAL CHANNEL FACIES

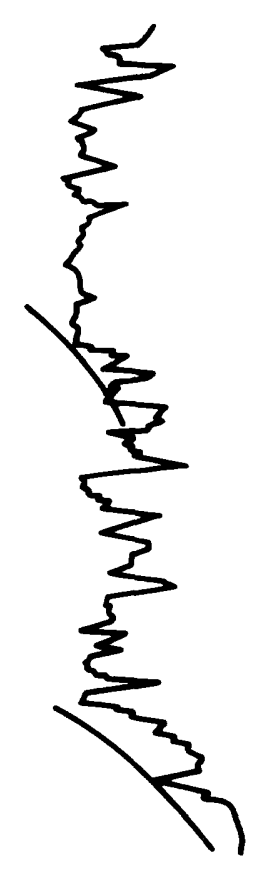

CHANNEL-CHANNEL MOUTH BAR FACIES (Progradational)

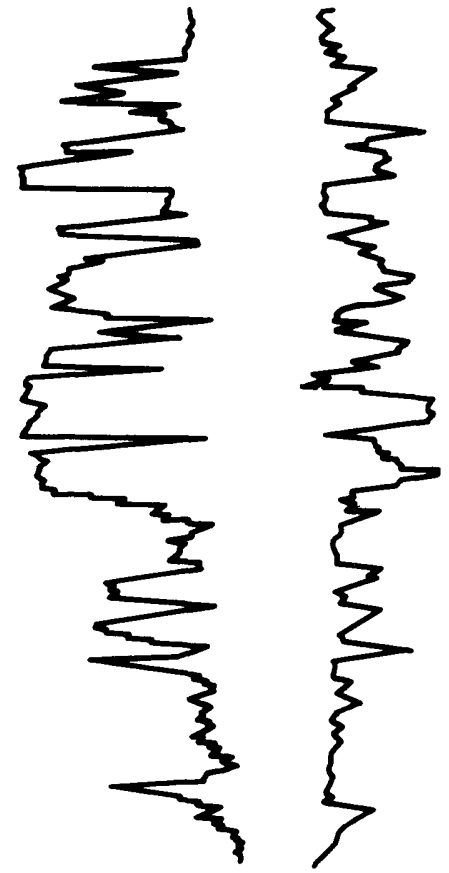

STACKED COASTAL BARRIER FACIES
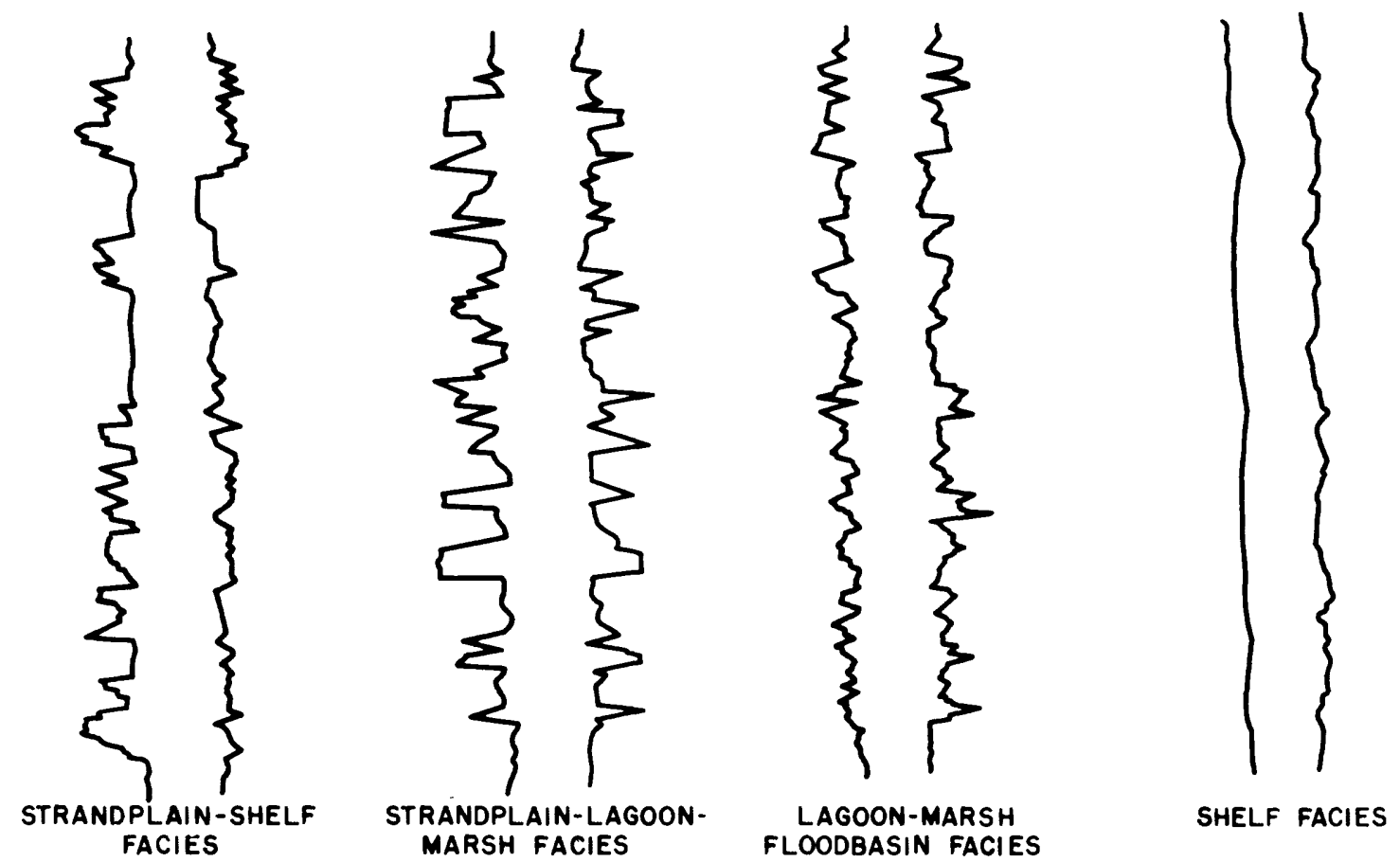

Figure 19,--Representative electric log patterns, high-destructive delta systems, Gulf Coast basin (Fisher, 1969a). 
facies. Fisher states $(1969 \mathrm{~b}$, p. 36) that: "The principal facies are those formed by marine processes, though these are associated both updip and along strike with fluvial and progradational facies, requisite in a delta system. Coastal progradation of terrigenous sediments was local and relatively uniform in a broad belt along regional strike; no extensive progradation like that of the Lower Wilcox high-constructive delta systems occurred. The recurrence along regional strike of several sand maxima gives a regional distribution not entirely unlike barrier bar systems (Boyd and Dyer, 1964) . Indeed, main accumulation was as a series of coastal barrier and strandplain sands. In contrast to barrier bar systems, the high-destructive delta systems of the Upper Wllcox show no well-defined updip lagoonal systems, and main sand masses are tied updip to supporting fluvial systems and contain local progradational sequences .

". . . The coastal barrier facies, developed adjacent to the channel mouth bar facies, is the most common facies in the downdip Upper Wilcox. Sequences in this facies show a series of sands with a box-like S. P. profile typical of strike-fed, marginal marine sands, alternating with thin marsh, lagoonal, or shelf muds . . . [see fig. 19]. In plan, sands of this facies are elongate, forming a cuspate or chevron pattern flanking local progradational facies which serves as source . . . [see fig. 18]."

The chevron pattern of sand trends in the coastal-barrier facies is shown in figure 20 and on plate 7. Fisher continues description of the deposits as follows (1969b, p. 36-37): "The strand-plain-shelf facles shows fewer and less well-developed sands downdip of the main sand mass and interbedded with thicker marginal marine muds. Updip of the main sand mass, 


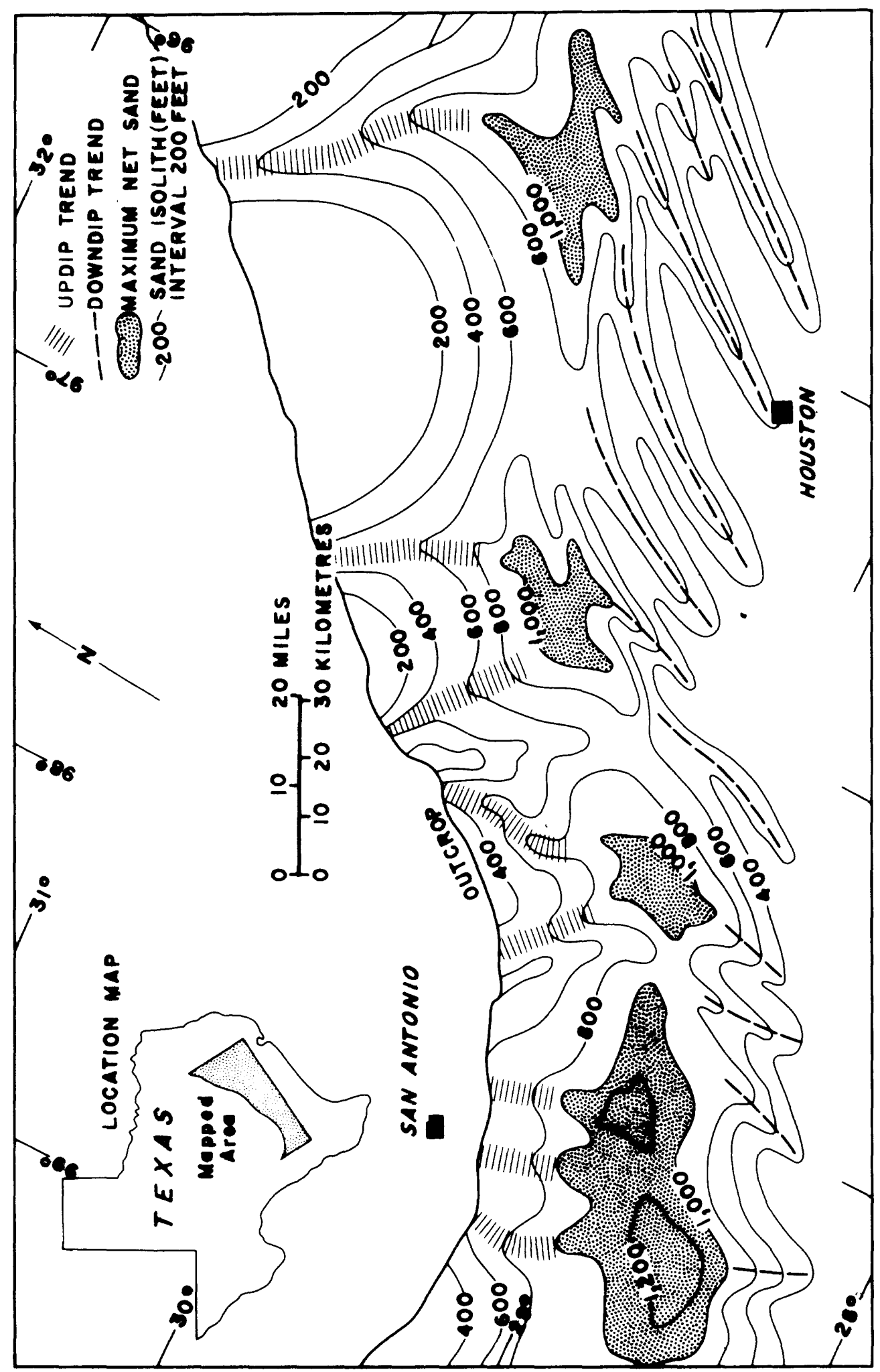

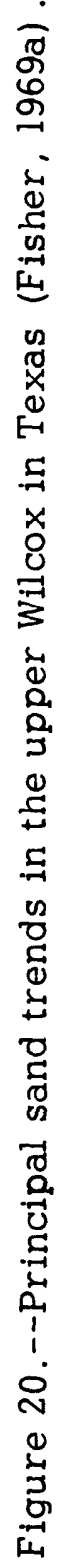


the strand-plain-lagoonal-marsh facles shows a series of sands having a box-like S. P. profile similar to the coastal barrier facies but with fewer and thinner sand units and also associated with muds containing a few local beds of lignite ... [see fig. 19] . . Prodelta muds are not thick in the high-destructive deltas, being mostly well-burrowed, fossiliferous, and slightly glauconitic muds, in contrast to the thick, laminated dark organicrich prodelta muds of the Lower Wilcox high-constructive deltas."

Within the well-defined boundaries of the sandy facies of the upper Wilcox, cumulative thickness of sand beds is about $1,000 \mathrm{ft}(305 \mathrm{~m})$ in seven "pods", most of them markedly elongate coastwise. Unlike the lower Wilcox, the largest and thickest "pods" of cumulative sand-bed thickness are southwest of the San Marcos arch. However, the entire belt of deposits classed as Channel Mouth Bar facies and Coastal Barrier facies includes sand beds of great areal continuity and rather uniform texture. Cumulative thickness of sand beds in the belt is about $500 \mathrm{ft}(152 \mathrm{~m})$, decreasing abruptly gulfward in the Strandplain Shelf facies. Landward they thin gradually in the Fluvial Channel facies.

Near the outcrop, the upper Wilcox increases in thickness southwestward from about $1,000 \mathrm{ft}(305 \mathrm{~m})$ in northern Nacogdoches County to about 1,500 ft $(460 \mathrm{~m})$ in northern Burleson County. Farther southwestward, in northern Gonzales County, the thickness is only about $900 \mathrm{ft}(270 \mathrm{~m})$; and in southern Zavala County, near the Rio Grande, it is only about $400 \mathrm{ft}(120 \mathrm{~m})$ thick.

On geologic section $A-A^{\prime}$ (pl. 2), the upper Wilcox increases in thickness downdip to about $1,400 \mathrm{ft}(430 \mathrm{~m})$ in western LaSalle County. It is about $1,800 \mathrm{ft}(550 \mathrm{~m})$ thick at the landward margin of the upper Wilcox Growth 
Fault Trend. Gulfward it thickens across successive growth faults and is about 2,500 ft $(760 \mathrm{~m})$ thick in north-central Duval County.

On section $B-B^{\prime}(p l .3)$, its thickness increases gradually to about $1,100 \mathrm{ft}(340 \mathrm{~m})$ in southeastern Gonzales County and to about $1,300 \mathrm{ft}$ $(400 \mathrm{~m})$ at the landward limit at the upper Wilcox Growth Fault Trend. Gulfward it thickens across successive growth faults to about 2,600 ft $(800 \mathrm{~m})$ in central Victoria County.

On geologic section $\mathrm{C}^{-C^{\prime}}$ (pl. 4), the upper Wilcox deposits thin gulfward from $1,500 \mathrm{ft}(460 \mathrm{~m})$ at the outcrop to about $1,200 \mathrm{ft}(370 \mathrm{~m})$ in northwestern Harris County; in central Harris County, its strandplain facies is about $2,300 \mathrm{ft}(700 \mathrm{~m})$ thick.

On geologic section $D^{-D^{\prime}}$ (pl. 5), the upper Wilcox thickens gradually from about $1,000 \mathrm{ft}(310 \mathrm{~m})$ near the outcrop to about $1,600 \mathrm{ft}(490 \mathrm{~m})$ in southeastern Polk County. Gulfward, past the Wilcox flexure where the strandplain facies occurs, its thickness is not known.

Along the coastwise section E-E' (pl. 6), the upper Wilcox gradually increases in thickness northeastward from about $900 \mathrm{ft}(270 \mathrm{~m})$ at the Rio Grande in west-central Webb County to about $1,400 \mathrm{ft}(430 \mathrm{~m})$ in westcentral LaSalle County. Northeastward as far as southwestern Gonzales County, the thickness is greater than $1,300 \mathrm{ft}(396 \mathrm{~m})$. From central Gonzales to central Lavaca County, thickness ranges from 800 to $900 \mathrm{ft}$ (244 to 274 m). Eastward from central Lavaca County, it thickens across successive growth faults and is about $1,300 \mathrm{ft}(400 \mathrm{~m})$ thick in eastern Lavaca County . Northward it thins to $900 \mathrm{ft}(275 \mathrm{~m})$ in south-central Colorado County . To the northeast, as far as northwestern Montgomery County, the thickness 
ranges from 1,000 to $1,200 \mathrm{ft}$ ( 305 to $366 \mathrm{~m}$ ). And from Montgomery County to the Sabine River, the upper Wilcox ranges from 1,200 to 1,400 ft (366 to $427 \mathrm{~m})$ in thickness.

Deposits of the upper Wilcox are probably better sorted and more uniform in thickness and texture than those of the lower Wilcox. These include extensive thick sand sequences such as the Carrizo to depths of about $5,000 \mathrm{ft}(1,525 \mathrm{~m})$ in Atascosa, Karnes, and Live Oak Counties. Consequently, they can be mapped with greater success. But areal distribution, total cumulative thickness, and variety of associated deposits are greater in the lower Wilcox.

In summary, Wilcox deposits have been explored in considerable detall, mainly by ofl test wells--from which a great deal of information has been obtained by study of cuttings and cores regarding lithology and faunal record. Electric logs have been made for most of these wells. Electriclog interpretation based upon sediment facies recognition provided the principal key to identification of depositional systems and their mapping at regional scale. Analysis of depositional systems in terms of the thickness, texture, clay content, and areal continuity of sand beds, as well as the geometric form and internal structure of sand units--in a clay-silt matrix-will make possible the appraisal of mapped rock units as aquifer systems, with special reference to storage of fluid wastes.

CLAIBORNE GROUP.--The Clalborne Group of middle Eocene age overlies the upper Wilcox (in subcrop) in the study area. Here, deposits of the Claiborne Group are much like those of the Wilcox Group in composition and texture, but the Claiborne includes a much greater amount of calcareous 
rock--highly fossiliferous marine marl, limey shale, and limestone--and shows at least two major cycles of marine transgression and regression. According to Murray (1961, p. 382), "Characteristically these cyclic sequences consist of basal, glauconitic, calcareous, fossiliferous, arenaceous-argillaceous (transgressive strata overlain by dark argillaceous (inundative) beds which are partly calcareous, fossiliferous, and glauconitic. At the top of the sequence are carbonaceous to lignitic arenaceous-argillaceous (regressive) strata."

Murray shows (1961, p. 380; fig. 6.41) that, along a strike section from the Rio Grande (Zapata County) to the Sabine River, the Claiborne Group thins rapidly northeastward to the San Marcos arch and thickens gradually eastward from the arch. Its basal shale and marl of the Cane River Formation at the Sabine River (named the Weches Formation in eastern Texas and the Urbeno Formation on the Rio Grande) is a marine deposit from Mexico to Louisiana along this line of section. However, it rises in the section southwestward. In the east Texas Coastal Plain it is underlain by both the Queen City and the Reklaw Formations, which are basal Claiborne in most of the study area.

The Reklaw is mainly carbonaceous clay with a basal marine marl member (the Newby) northeast of the Nueces River. To the southwest it thickens and grades rapidly into lignitic and carbonaceous sand and clay--becoming indistinguishable from the overlying Queen City. This change in lithology southwestward is shown on geologic section E-E' (pl. 6), between central Atascosa County and the Rio Grande. Elsewhere along section E-E', the uppermost deposits of the upper Wilcox--everywhere 
including many sand beds--are overlain by massive clay deposits ranging in thickness from 200 to $2,000 \mathrm{ft}(60$ to $610 \mathrm{~m})$ or more.

On the dip sections, the Reklaw is mainly marine shale, ranging in thickness from about $50 \mathrm{ft}(15 \mathrm{~m})$ to about $300 \mathrm{ft}(90 \mathrm{~m})$ at depths about $4,000 \mathrm{ft}(1,220 \mathrm{~m})$ below sea level. Gulfward, at depths of 7,000 to $8,000 \mathrm{ft}$ $(2,134$ to $2,438 \mathrm{~m})$ below sea level, thickness of the marine shale--of which here is not all Reklaw equivalent--increases to $1,000 \mathrm{ft}(305 \mathrm{~m})$ or more. The overlying Queen City, and even the Sparta Sand, grade into marine shale gulfward (Lowman, 1949, p. 1972).

On section $A-A^{\prime}$ (pl. 2), the Reklaw is mainly sand inland from eastern Dimmit County, where it occurs at depths less than $1,000 \mathrm{ft}(305 \mathrm{~m})$ below sea level. Except in this area, no part of the upper Wilcox sand-bed system is overlain by sandy deposits. Thus, throughout the rest of the study area the uppper Wilcox boundary is marked by clay or shale above and sand below. The percent shale and the cumulative thickness of shale in the overlying Claiborne deposits increase rapidly gulfward.

\section{Structure}

The structural framework of the Gulf Coast province and its development since the late Paleozoic are discussed earlier in the section entitled "Principal Features". The relative importance of inherited structural elements, and of those classed as sedimentary tectonics (Krumbein, Sloss, and Dapples, $1949, p .1860)$, has been reviewed with respect to the principal structural aspects of the study area. This review suggests that the geologic structure of the stable shelf, or platform, comprising the landward half of the Texas Coastal Plain (figs. 2, 5, and 6) is primarily related to pre-existing faults, 
fault zones, crustal upwarp or downwarp, and to the loadbearing strength, or competence, of underlying rock formations--including salt. Structural features of the gulfward half of the Texas Coastal Plain are primarily related to sedimentary tectonics, including differential compaction of sand and clay, salt and shale diapirism (Weller, 1959, p. 273-310; Bornhauser, 1958, p. 339-370; Atwater and Forman, 1959, p. 2592-2622; Halbouty, 1967, 425 p.), and downwarp on the northwest limb of the Tertiary Gulf Coast geosyncline (Barton and others, 1933, p. 1446-1458). (See figs. 2 and 3.) The principal features of sedimentary tectonics associated with rapidly repeated cycles of deltation where no salt substrate is present are shown in figure 4 .

\section{HYDROTHERMAL TECTONISM}

Both the rapid rate and great magnitude of structural deformation associated with Wilcox sedimentary tectonics are the result of a previously unrecognized, or at least undocumented phenomenon--here termed hydrothermal tectonism. Effects of this process are extremely important in the structural evolution of the Gulf Coast geosyncline and perhaps more important in the middle and late Tertiary than in the early Tertiary. Hydrothermal tectonism is keyed to thermal diagenesis of the clay mineral montmorillonite (Burst, 1969, p. 73-93) and to the resulting loss of watersorption capacity and load-bearing strength. The volume of water released by this mineral conversion is roughly equal to half the volume of clay mineral altered (Powers, 1967, p. 1240-1253). According to Burst (p. 80) it is equal to " 10 to 15 percent of the compacted bulk volume" of the rock 
and "is the most significant fluid displacement subsequent to the initial pore-water drainage."

Perhaps two-thirds of the total mass of Tertiary deposits in the Gulf Coast geosyncline is clay, of which 50 to 70 percent was deposited as montmorillonite (Milne and Early, 1958, p. 328). According to Burst (1969, p. 80), "Clay compaction as a result of interlayer water discharge is postulated to be an essentially temperature-dependent phase change in which a silicate lattice hydrate (montmorillonite) begins to dehydrate at a critical temperature in the $200-230^{\circ} \mathrm{F}\left(93-110^{\circ} \mathrm{C}\right)$ range, regardless of burlal depth." When the geotemperature regime in any area is known, the depth at which the process occurs can be approximated using the graphs in figure 21 (Burst, p. 9l, fig. 16). Adaption of the graph is necessary, as there are no straight line geothermal gradients in these sediments.

The geothermal flux of the Gulf basin resulted in a progressive rise in temperature of sediments deposited in the basin, in time and with depth of burial. Thus, the zone of clay-mineral diagenesis and fluld release moved upward through the deposits with time. Loss of loadbearing strength of the deposits at depth produced a substrate capable of compaction. This compaction was dependent almost entirely upon the rate at which deposits could drain. This rate was in turn dependent upon the upward hydraulic gradient and permeability. In thick clay sequences, release of free pore water by thermal diagenesis of montmorillonite exceeded the rate at which it could escape from clay beds. Interstitial water pressure rose as pore 


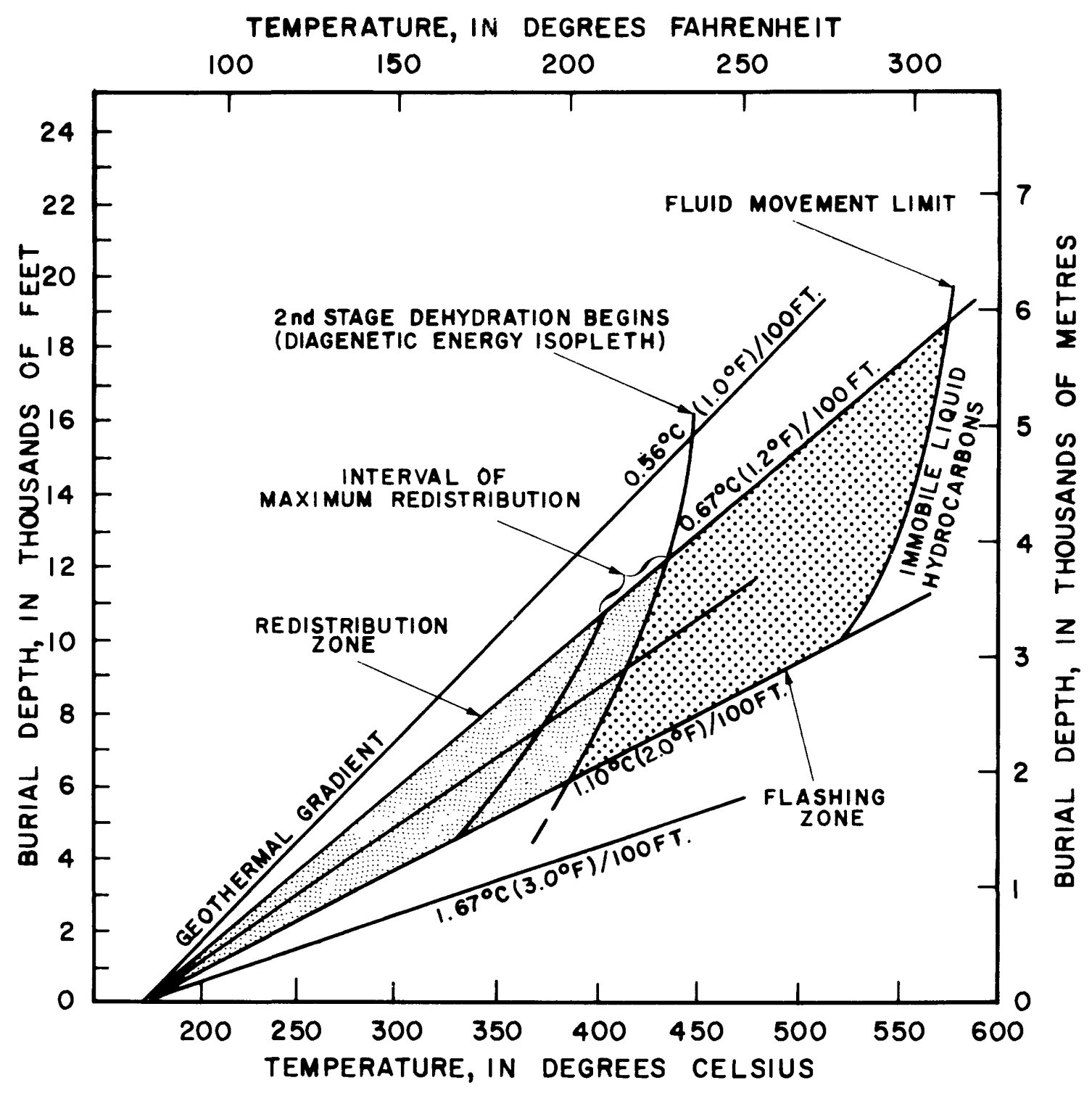

Figure 21.--Fluid-redistribution model, Gulf Coast area (Burst, 1969) . 
water carried an increasing part of the overburden load. When the fluid pressure approached the weight of the overburden, leakage began at the top of the pressured section. Leakage resulted in clay compaction, which, being unequal in different directions, caused shearing stresses. Faults developed; therefore, the fault planes then served not only to accommodate differential loss of rock volume but also as principal avenues of water movement from the compacting mass of geopressured clay (Stuart, 1970, p. 2). Large faults formed where lithologic changes from sand to clay occurred. These faults were propagated downward in a direction and at an angle which is a function of the pressure gradient (Bruce, 1973, $p$. 886) (see fig. 22).

Water lost upward was at or above temperatures required for thermal diagenesis of montmorillonite. As this water entered and heated overlying and adjacent deposits, a "wave" of clay-mineral diagenesis passed through them, producing another series of structural and hydrodynamic effects .

The gulfward margin of known Wilcox deposits is a maze of normal faults in which the upper Wilcox beds are growth faulted, and all Wilcox beds are geopressured (pl. 8). Updip from this upper Wilcox growth fault zone, Wilcox beds are cut by normal faults which terminate in beds of Clatborne or younger age. Here, upper Wilcox beds, in which the water is hydropressured (Stuart, 1970, p. 2), overlle lower Wilcox beds that are partially or entirely geopressured and growth faulted. The entire fault complex is the Wilcox flexure, part of which has long been known as the Mirando-Provident City Fault zone. 


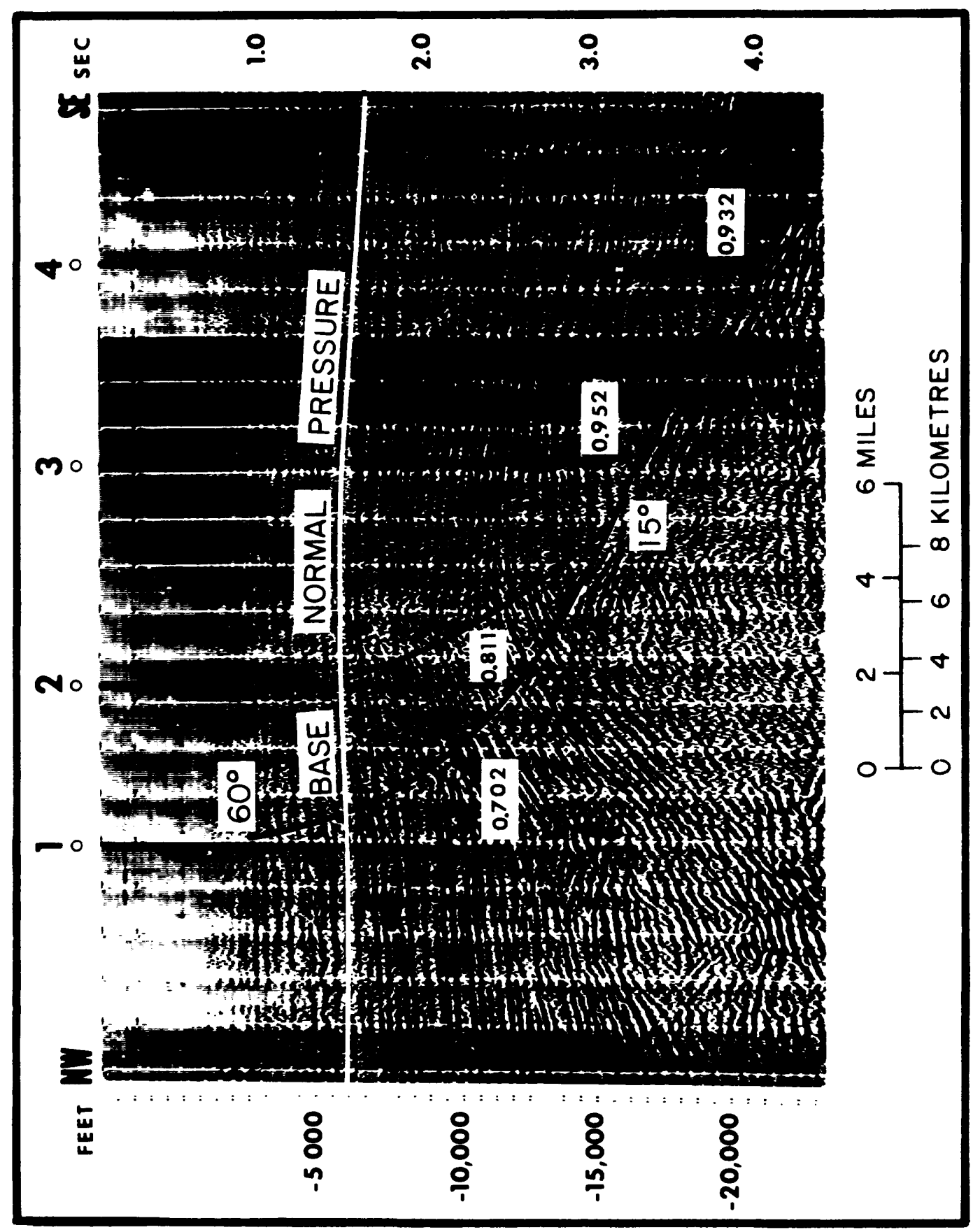


The major structural features of the Wilcox Group in Texas, as indicated by the configuration of 1 ts upper surface, are shown on plate 8 . Important features are: The upper Wilcox Growth Fault Trend and the upper Wilcox Postdepositional Fault System, which together comprise the Wilcox flexure; and the gentle gulfward-steepening slope of Wilcox beds in the broad relatively stable area landward from the Wilcox flexure.

The top of the Wilcox is about $7,000 \mathrm{ft}(2,130 \mathrm{~m})$ below sea level along the landward margin of the Wilcox flexure, except in the Rio Grande embayment, where it is about $5,000 \mathrm{ft}(1,520 \mathrm{~m})$ below sea level. The stable sloping area extends inland about $70 \mathrm{mi}(115 \mathrm{~km})$ from the Wilcox flexure on geologic section $A-A^{\prime}$ (fig. 23), about $40 \mathrm{ml}\left(65 \mathrm{~km}\right.$ ) on $B-B^{\prime}$ (fig. 24), about 60 $\mathrm{ml}(95 \mathrm{~km})$ on C-C' (fig. 25), and about $75 \mathrm{ml}(120 \mathrm{~km})$ on D-D' (fig. 26) .

The area now underlain by the upper Wilcox Postdepositional Fault System was the gulfward margin of a stabie shelf, or platform, during lower Wilcox time. These post-depositional faults are not the result of renewed movement along faults inherited from pre-Tertiary structure; they result from adjustments caused by post-depositional changes in the load-bearing strength of clay beds in Late Cretaceous, Paleocene, and Eocene deposits. In some places upper Wilcox postdepositional faults appear to be reactivated lower Wilcox faults. Displacement on the faults of this system can be traced into the overlying Clalborne deposits, where they appear as growth faults. The time when movement stopped is indicated by the age of beds immediately above the fault "die-out." 


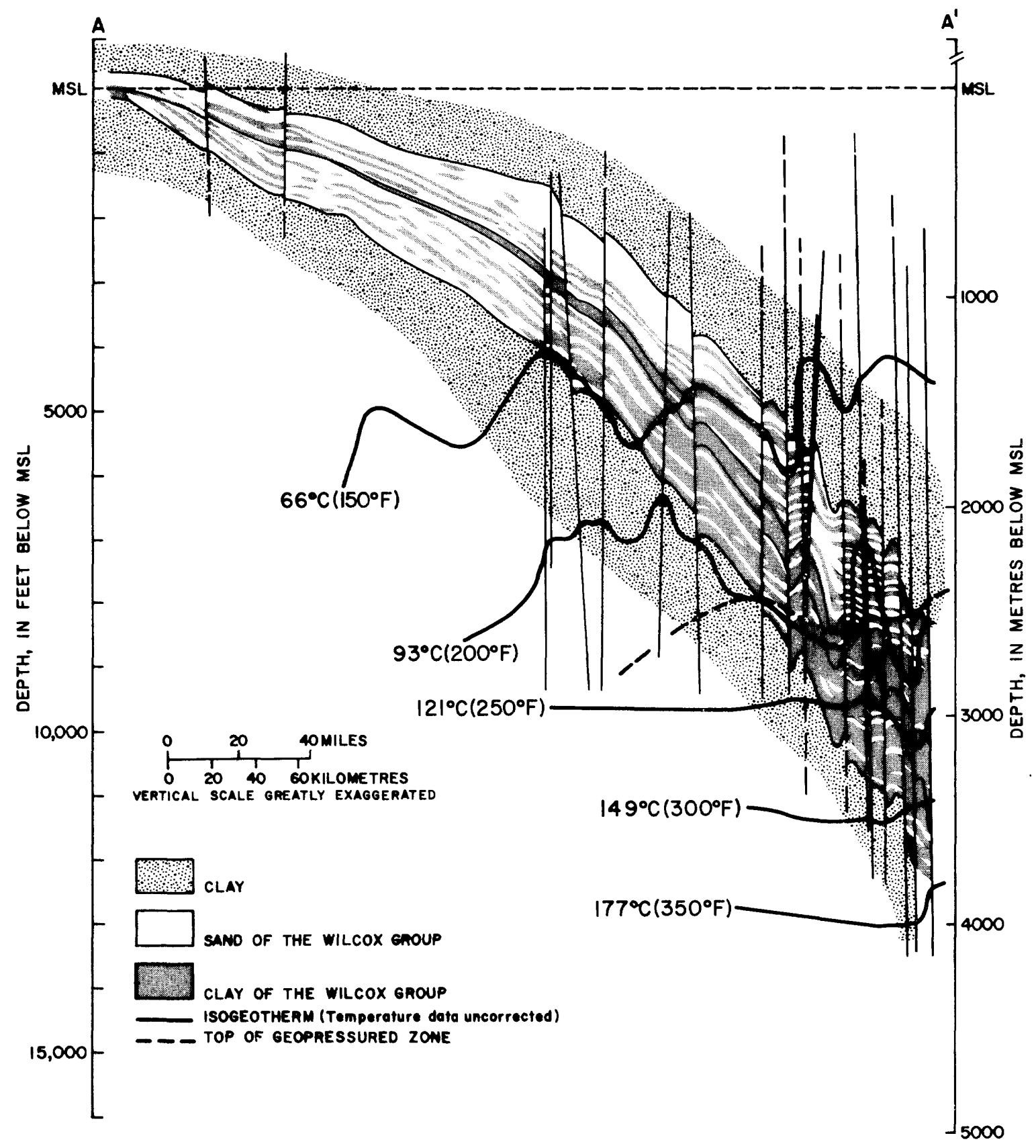

Figure 23.--Relation of isogeothermal surfaces, top of the geopressured zone, and structural features along line $A-A^{\prime}$, as shown in figure 5. 


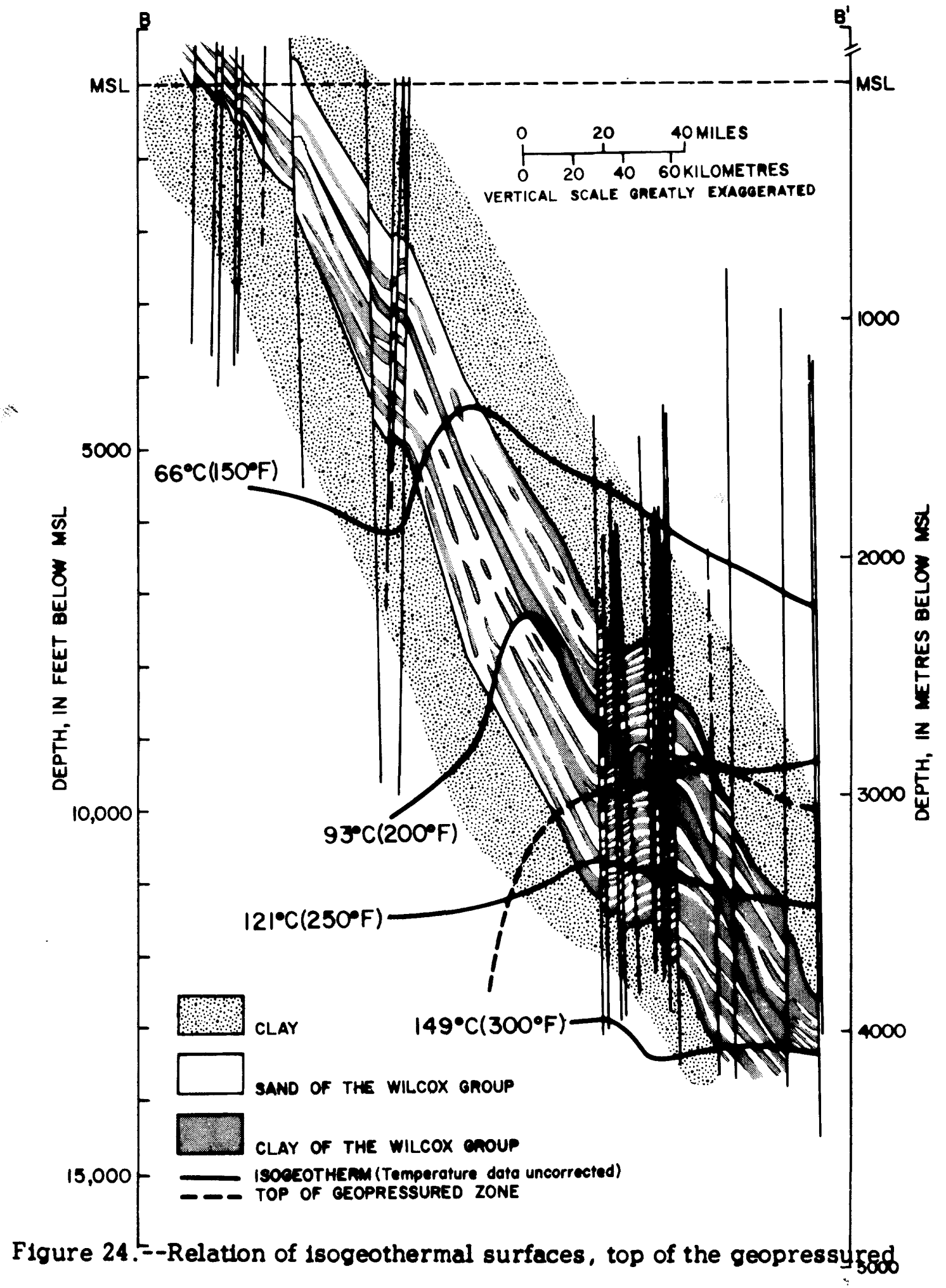

zone, and structural features along line B-B', as shown in flgure 5 . 


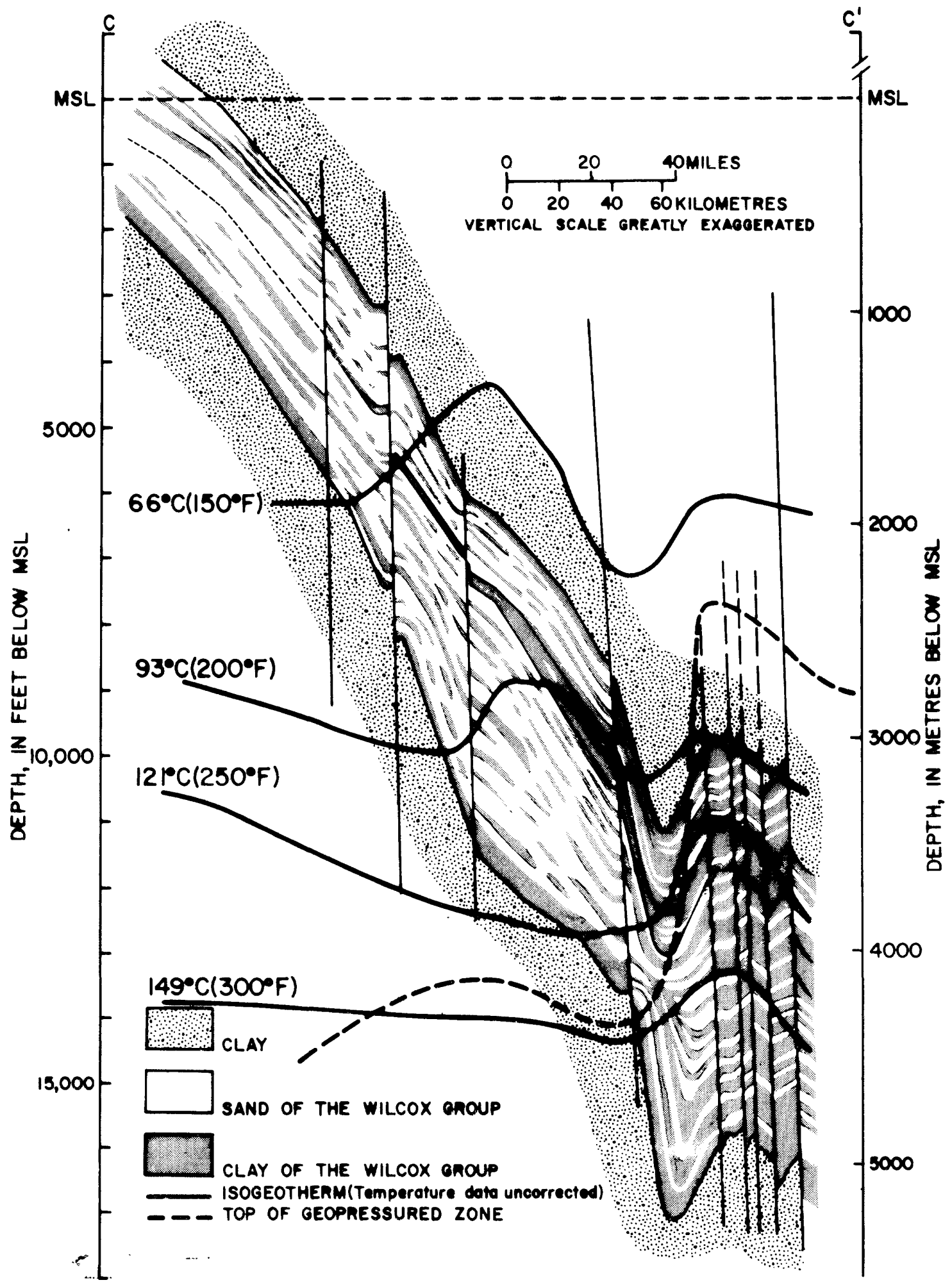

Figure 25.--Relation of isogeothermal surfaces, top of the geopressured zone, and structural features along line $C-C^{r}$, as shown in figure 5 . 


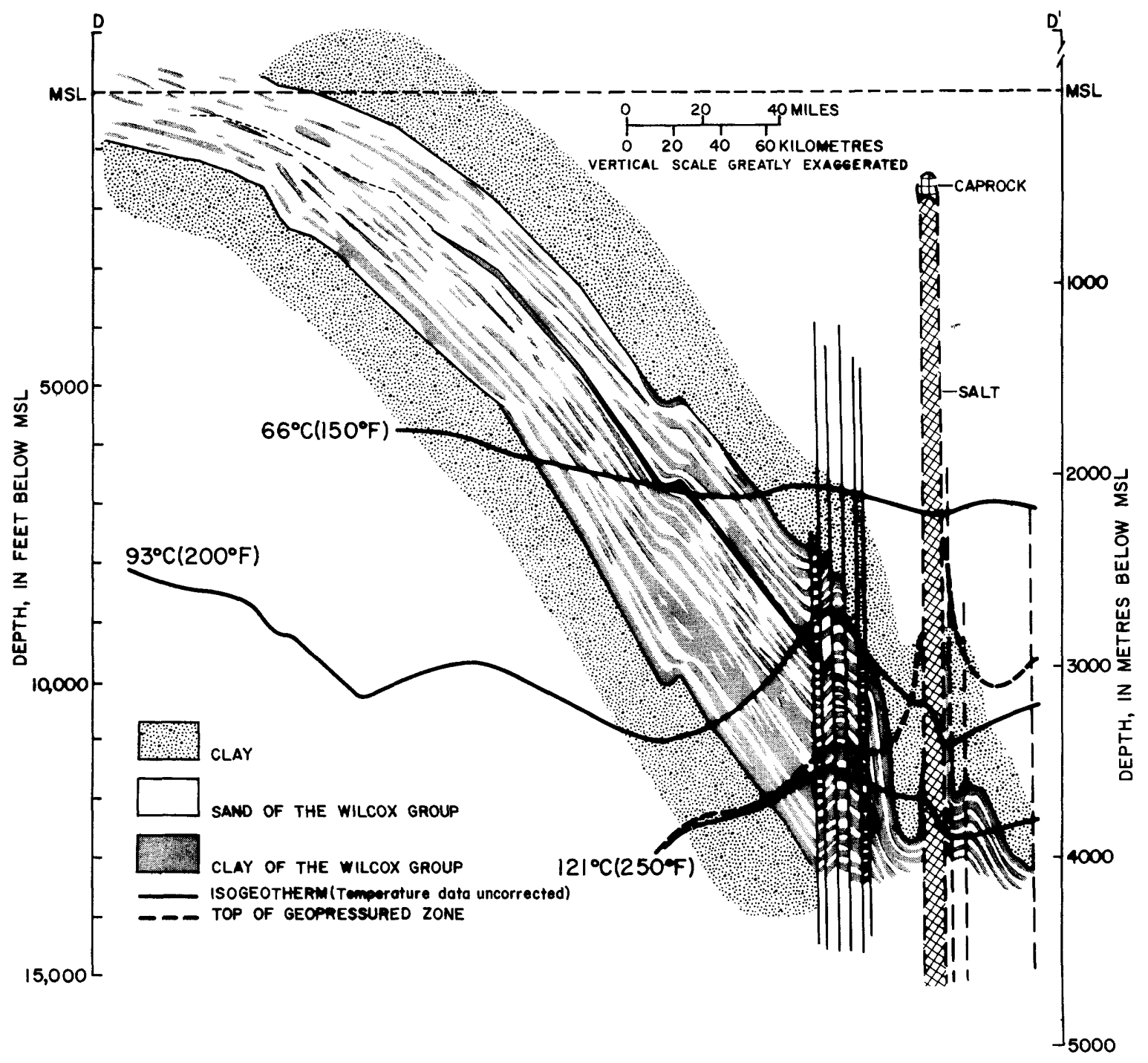

Figure 26.--Relation of isogeothermal surfaces, top of the geopressured zone, and structural features along line $D-D^{\prime}$, as shown in figure 5. 
That structural deformation was accompanied by movement of geothermal water into sand-bed aquifers in the belt now occupled by the Wilcox postdepositional Fault System is evident on the four diagrammatic structural dip sections, figures 23-26 (for locations, see fig. 5). In this belt, the top of the geopressured zone now ranges from about $8,000 \mathrm{ft}(2,440 \mathrm{~m})$ to about $14,000 \mathrm{ft}(4,270 \mathrm{~m})$ below sea level. In the adjacent upper Wilcox Growth Fault Trend on individual sections, the full thickness of the Wilcox is geopressured, and temperature is greater than $200^{\circ} \mathrm{F}\left(93^{\circ} \mathrm{C}\right)$. None of the upper Wilcox deposits are geopressured landward from the zone of upper Wilcox post-depositional faults, regardless of temperature, except where diapiric structures occur, for example, adjacent to piercement salt domes. Consistent relationships exist between the width of the belt of upper Wilcox post-depositional faults, the occurrence of delta front and strand-plain sedimentary facies of the lower Wilcox, and depth to the top of geopressure (fig. 24). The top of the geopressured zone coincides closely with the $200^{\circ} \mathrm{F}\left(93^{\circ} \mathrm{C}\right)$ isotherm through the upper Wilcox and into the marine middle Wilcox; but they separate abruptly at the top of the lower Wilcox. Updip, the geopressured zone dies out obliquely downward, but the $200^{\circ} \mathrm{F}\left(93^{\circ} \mathrm{C}\right)$ 1sogeotherm rises more than $2,000 \mathrm{ft}(610 \mathrm{~m})$, closely following the upper boundary of the lower Wilcox. Farther updip, a corresponding rise occurs in the $150^{\circ} \mathrm{F}\left(66^{\circ} \mathrm{C}\right)$ isotherm. These isothermal profiles, their relation to the top of geopressure, and landward die-out of the fault zone in the Wilcox can be attributed to updip sediment facies transition, from interbedded clay and sand in the delta-front sediments to massive delta-plain sand. The expelled warm water traveled through the sand beds updip and away from the faults, and there was not enough clay in the sequence to produce faulting by dehydration and compaction. 
Similar conditions are shown in figure 25 , but locally, temperature and pressure were affected by the Hockley salt dome which is near the line of section. Here the isothermal and geopressure surfaces are depressed. At Saratoga salt dome (fig. 26), the isotherms are depressed and the top of the geopressure zone is markedly raised. Sediment facies change is responsible for pressure-temperature relations; Hockley salt dome penetrates the lower Wilcox at the juncture of the delta-plain sediment facies and the prodelta facies, where formation water is free to move; Saratoga salt dome penetrates only prodelta and strand-plain-shelf sediment facies-a relatively impermeable mass of deposits.

The maze of fault blocks developed in the inland portion of the upper Wilcox flexure suggests that, as heated water escaped from the geopressured zone (downdip) into sands of the hydropressured zone (immediately updip), the clays were heated above critical temperature, that is about $200^{\circ} \mathrm{F}$ $\left(93^{\circ} \mathrm{C}\right)$, initiating thermal diagenesis. Clay-mineral diagenesis is an endothermic chemical reaction, so the invading thermal waters were cooled as the reaction progressed and as distance from the geopressured source aquifer increased. Simultaneously with clay-mineral diagenesis, released water was expelled by compaction of clay beds into the very same sandbed aquifers responsible for bringing in the heated water. This influx greatly reduced--and may even have again reversed--the gradient in head in the system, as flow from the geopressured source aquifer slowed or ceased. This appears to have been a cyclic process, as faults induced by the thinning of clay beds cut off interbedded sand aquifers and restricted flow. Fault closures by this process, probably aided by cementation, resulted in geopressure in block after block of the formerly hydropressured zone, thus allowing faulting to move updip. 
Subsequent to the compartmentalization of aquifer segments, and the confinement and geopressuring of water in them, geothermal heating progressed at an accelerated rate (Jones, 1970, p. 22). As temperature rose above the critical value $\left(200^{\circ} \mathrm{F}\right.$ or $\left.93^{\circ} \mathrm{C}\right)$ and heating continued, thermal diagenesis of montmorillonite was carried to endpoint. Released water contributed to maintenance of geopressure, but in some cases it escaped with time. In these cases, faulting and subsidence continued until compaction of the clay beds (now predominantly illite) was complete. These processes lllustrate the extent of hydrothermal tectonism.

The landward margin of the Wilcox flexure overlles the gulfward margin of the Cretaceous carbonate-reef system (fig. 5) between the South Texas Salt Basin and the Houston Embayment Salt Basin. Here, in addition to drainage into the updip Wilcox sand, escape of geopressured-geothermal water from Paleocene, lower Eocene, and Upper Cretaceous deposits into permeable Cretaceous limestone was possibly effective in checking the landward spread of the Wilcox flexure at its present position. The effects of diapirism have completely changed the structural character of the flexure in the Houston Embayment Salt Basin. The salt-diapir complex marked by the San Felipe, Hockley, and Racoon Bend domes, and the accompanying Katy anticlinal structure in Austin, Waller, Colorado, Fort Bend, and northwestern Harris Countles, completely transects the Wilcox flexure, terminatIng or deflecting all faults. Salt was probably present beneath the narrow marine subembayment in this area during Rockdale time (pl. 1). It probably began to rise through soft marine clay as deltalc sand was deposited in this area during Carrizo time (fig. 26 and pl. 7). Thus, the semiplastic 
clay-salt substrate in this area localized deltaic lobes that formed there by subsiding under load, making possible local accumulation of deposits with cumulative sand-bed thickness ranging from 600 to $800 \mathrm{ft}$ (183 to 244 $m$ ). In the South Texas Salt Basin, effects of salt diapirism are noted, but are not nearly so great--probably because of the rather uniform character and widespread occurrence of the main sedimentary facies of the Wilcox in this area as well as, possibly, less salt.

The locations of all salt domes known to plerce or deform Wilcox deposits are shown on plate 8; they are listed by name, and the shallowest depth at which salt was penetrated is noted. In south Texas, the Moca dome in Webb County penetrates the Wilcox, but netther the Pescadito nor the Dilworth Ranch domes (in Webb and McMullen Counties) plerce it. In the Houston embayment, diapiric salt penetrates the full thickness of the Wilcox at Brenham, Hockley, San Fellpe, Clay Creek, Orchard, Humble, Davis Hill, Batson, Saratoga, and Arlola domes; salt penetrates the Wilcox at Racoon Bend, Millican, Ferguson's Crossing, Day, and Kittrell domes. In the East Texas embayment, 10 of the 18 salt domes penetrate, or pass through, the Wilcox.

Structural features of the Inner Texas Coastal Plain have marked effect upon Wilcox deposits--their type, distribution, thickness, and postdepositional deformation. The degree to which inland fault systems shown on plate 8 were effective in these processes differs greatly.

The inland boundary of the Wilcox closely parallels the CretaceousTertiary contact in Texas; its trend is controlled by the Balcones, Luling, and Mexia fault systems. These systems in turn follow the Ouachita structural belt in Texas (King, 1959, p. 69) (see fig. 5). Effects of the San 
Marcos arch, Sabine uplift, Rio Grande embayment, and the East Texas basin (fig. 6) are reflected in the trend of outcrop of the Wilcox Group. Major river systems that flowed from older rocks onto and over Tertiary deposits to the Gulf of Mexico were located by pre-existing structure or topography. Their entrance into the Tertiary is through entrenched valleys in the older rocks. These systems furnished most of the sediments. This initial entrenchment in part explains the repetitive and stacked nature of sedimentation. Structural effects of the Rio Grande embayment and the East Texas basin are shown by the concave landward trend of the Wilcox outcrop, and the corresponding strike of its beds (fig. 6 and pl. 8) . The effects of the San Marcos arch-Llano uplift and the Sabine uplift tend to cause the regional strike of Wilcox beds to arc coastward. Faultline trends of the Sample, Charlotte, and Luling Systems (pl. 8) are closely spaced in the vicinity of the San Marcos arch and fan out northeastward and southwestward into the embayments. The interior fault systems-the Balcones and Luling--attain their maximum displacements across the San Marcos arch (Weeks, 1945, p. 1733).

Gulfward from the Sample Fault System and the Grimes-Angelina arch, downwarp of the northwest limb of the Gulf Coast geosyncline is the dominant structural control. The axis of the geosyncline (fig. 6) trends southwestward to the mouth of the Rio Grande embayment. It then turns south, and perhaps slightly southeastward, reflecting influence of the Sierra Madre Oriental in Mexico.

Thickness of the Wilcox Group ranges from about $500 \mathrm{ft}(150 \mathrm{~m})$ near the outcrop to about $7,000 \mathrm{ft}(2,130 \mathrm{~m})$ at the gulfward limits of 
control. Thickness increases uniformly gulfward to the inland margin of the Wilcox flexure where bed thickness increases abruptly gulfward across down-to-the-basin faults.

The average dip of beds in the stable-shelf area inland from the Wilcox flexure is about $55 \mathrm{ft} / \mathrm{ml}(10 \mathrm{~m} / \mathrm{km})$ (pl. 8); however, in the East Texas basin, beds are almost horizontal. Southeastward from the East Texas basin, gulfward dip of Wilcox beds steepens across Nacogdoches County, flattens at the northern margin of the Grimes-Angelina arch, and steepens on its southern flank (pl. 5 and fig. 26). Structural effects of the arch can be seen on geologic cross sections $C^{-} C^{\prime}$ (fig. 25), D-D' (fig. 26, and $E-E^{\prime}(p l .6)$. The steepening dip in the vicinity of the arch on section D-D' may be attributed to the Sabine uplift. On geologic cross section B-B' (pl. 3 and fig. 24), which follows the axis of the San Marcos arch, dip is about $180 \mathrm{ft} / \mathrm{ml}(34 \mathrm{~m} / \mathrm{km})$.

Immediately updip from the Wilcox flexure, the dip of beds is least In the Houston Embayment Salt Basin (fig. 5 and 6), being about $125 \mathrm{ft} / \mathrm{mi}$ $(24 \mathrm{~m} / \mathrm{km})$ at depths of about $4,000 \mathrm{ft}(1,220 \mathrm{~m})$ (pl. 8). Dip is greatest-about $700 \mathrm{ft} / \mathrm{mI}(133 \mathrm{~m} / \mathrm{km})--1 \mathrm{n}$ central Zapata County, where the Coahuila marginal fold belt has had effect.

The principal structural feature of the Wilcox Group is the normal, or gravity fault. The dip of fault planes is shown on plate 8 and is about 45 degrees where faults cut the uppermost beds of the group. Strike of the principal faults is everywhere parallel to, or at small angles to, the strike of the beds--except in the Houston Embayment Salt Basin . 
Updip of the Wilcox flexure, evidence of Wilcox and post-Wilcox movement along pre-existing faults is common. Immediately gulfward from the vicinity of Wilcox outcrop, regional fault systems in which Wilcox beds in the stable-shelf area have been displaced include the Luling, Mexia, Charlotte, Mount Enterprise, and Sample. These systems are formed by normal faults, with displacement either up-to-the-coast or down-to-the-coast.

They occur as zones, some forming en echelon grabens trending northeastsouthwest across the Texas Coastal Plain (pl . 8). Faults of these systems commonly reach land surface, creating topographic relief. The Luling, Mexia, Charlotte, and Sample Fault Systems may be traced many miles, whereas the Mount Enterprise Fault System is restricted to the southern end of the East Texas basin (fig. 5 and pl. 8). According to Murray (1961, p. 188), the Mount Enterprise Fault System has no apparent relationship to other regional fault systems. Displacements of a few feet to several hundred feet ( 1 to $100 \mathrm{~m}$ ) have been noted in Eocene strata cut by these faults; displacements of 600 to $700 \mathrm{ft}$ ( 183 to $213 \mathrm{~m}$ ) on the same faults have been noted in underlying Cretaceous beds (Murray, 1961, p. 188) .

The Luling Fault Zone is the landwardmost fault system in which Wilcox beds are displaced. Hendy (1957, p. 23) credits early mapping of the Luling Fault to V. E. Woolsey and others, who discovered inliers of lower Wilcox sediments bounded on the southeast by an up-to-the-coast fault--the Luling Faults of the Luling System form an arc (convex gulfward) across the landward ends of the Rio Grande embayment and San Marcos arch (pls. 3 and 8). The system extends from Zavala County on the southwest, across the San Marcos arch to Williamson County on the northeast 
(Murray, 1961, p. 178). Faults of this zone have greatest throw and are most numerous from Travis and Bastrop Counties southwestward through Bexar County (Weeks, 1945, p. 1734). Reported cumulative displacement of 1,500 to $2,000 \mathrm{ft}(457$ to $610 \mathrm{~m}$ ) across the entire Luling System (Murray, 1961, p. 178) compares well with aggregate displacements combined with dip of as much as $1,700 \mathrm{ft}(517 \mathrm{~m})$ in the Balcones System (Sellards and others, 1935, p. 58). Predominantly landward-dipping faults of the Luling System, together with gulfward dipping faults of the Balcones System to the northwest, create a large, poorly-developed rift across the Inland area of the San Marcos arch (Murray, 1961, p. 178). Along the western side of this fault zone, transverse faults similar to those at the western end of the Charlotte System are found.

Murray (1961, p. 180) links the Charlotte and Mexia Fault Systems of Texas with the south Arkansas and Pickens-Gllbertown Systems in Mississippi and Alabama, around the northern margin of the Gulf Coastal Plain. According to Murray, this system represents a belt of major fracturing associated with collapse of the Gulf of Mexico basin. The Mexia Fault System forms a belt of grabens extending from Bastrop County northeastward to Hunt County, then eastward to Bowie County on the ArkansasTexas state line (pl. 8) .

The Charlotte System appears to be a southwestward extension of the Mexia System, from the southwest flank of the San Marcos arch to LaSalle County (Murray, 1961, p. 183). This zone of faulting lies coastward from the Luling Fault System and landward from the Sample Fault System. Fowler (1956, p. 38) calls attention to the distinct change in fault trend at 
the southwestern end of the Charlotte Fault System. At the Frio-Atascosa County line, the trend changes from slightly north-of-east to slightly eastof-north. This nearly north-south orientation is subparallel to the folds within the Rio Grande embayment. Fowler (1956, p. 41) cites evidence that two independent strain fields existed side-by-side in south-central Texas; the northeast-southwest trending folds and faults are related to subsidence in the Gulf Coast geosyncline.

The Sample (or Fashing) Fault System, most gulfward of the grabentype fault systems, lies between the Charlotte Fault System and the Wilcox flexure southwest of the San Marcos arch and between the Mexia Fault System and Wilcox flexure northeast of the arch (pl. 8). The trend of the Sample Fault System coincides with two synclinal troughs located 10 to $12 \mathrm{mi}(16$ to $19 \mathrm{~km})$ inland from the Stuart City Reef and on either side of the San Marcos arch (Tucker, 1962, p. 89). These synclinal troughs plunge southwestward and northwestward from the San Marcos arch. According to Tucker (1962, p. 89), "up-to-the-coast faults are dominant southeast of the axial part of the synclinal troughs and down-to-the-coast faults are dominant on the northwest." In northern Karnes County, displacement on individual faults of the Sample Fault System range from about 100 to 400 ft $(30$ to $120 \mathrm{~m})$ at depths of 2,000 to $5,000 \mathrm{ft}(610$ to $1,524 \mathrm{~m})$ below sea level and from 500 to $800 \mathrm{ft}(150$ to $245 \mathrm{~m})$ at depths of 10,000 to $11,000 \mathrm{ft}$ $(3,050$ to $3,350 \mathrm{~m}$ ) (Tucker, 1967, p. 146-147). Maximum displacement of down-to-the-coast faults in central Gonzales County is generally less than maximum displacement of up-to-the-coast counterparts in southern Gonzales County. Carrizo-Wilcox beds are offset 100 to $200 \mathrm{ft}(30$ to $60 \mathrm{~m})$ at depths 
of 1,000 to $2,000 \mathrm{ft}(305$ to $610 \mathrm{~m}$ ) below sea level in the vicinity of the San Marcos arch (pl. 8) .

Displacement on faults in the shelf area may be elther up-to-the-coast or down-to-the-coast. But along the Wilcox flexure, which is underlain by geopressured Wilcox deposits, almost all displacement is down-to-thecoast. In the inner shelf areas displacement on faults seldom exceeds 500 ft $(152 \mathrm{~m})$, and is generally much less; displacement about $1,000 \mathrm{ft}(305 \mathrm{~m})$ on single faults is common in the Wilcox flexure.

\section{CONCLUSIONS}

The presence of the geopressured sediments downdip and at depth are considered a positive barrier and, therefore, a limiting factor to use of these beds as a toxic waste disposal unit. The presence of freshwater In the outcrops and updip beds will constitute an updip limit to use of the Wilcox Group for this purpose.

In Part II these two boundary conditions will be mapped. Further definition of the hydrologic parameters of the Wilcox Group will be restricted to defining and interpreting the physical and chemical characteristics of the beds and fluids between these two zones. 


\section{REFERENCES CITED}

Alger, R. P., 1967, Interpretation of electric logs in fresh water wells in unconsolidated formations: Houston, Tex., Schlumberger Well Surveying Corp. , 25 p.

Atwater, G. I., and Forman, M. J., 1959, Nature of growth of southern Louisiana salt domes and its effect on petroleum accumulation: Am. Assoc. Petroleum Geologists Bull., v. 43, no. 11, p. 2592-2622.

Barton, D. C., Ritz, C. H., and Hickey, Maude, 1933, Gulf Coast geosyncline: Am. Assoc. Petroleum Geologists Bull., v. 17, p. 1446-1458.

Bornhauser, Max, 1958, Gulf Coast tectonics: Am. Assoc. Petroleum Geologists Bull., v. 42, no. 2, p. 339-370.

Boyd, D. R., and Dyer, B. F., 1964, Frio barrier bar system of south Texas: Gulf Coast Assoc. Geol. Soc. Trans., v. 14, p. 309-322.

Bruce, C. H., 1972, Pressured shale and related sediment deformation: a mechanism for development of regional contemporaneous faults: Gulf Coast Assoc. Geol. Soc. Trans., v. 22, p. 23-31. 1973, Pressured shale and related sediment deformation: mechanism for development of regional contemporaneous faults: Am. Assoc. Petroleum Geologists Bull, v. 57, no. 5, p. 878-886.

Burst, J.F., 1969, Diagenesis of Gulf Coast clayey sediments and its possible relation to petroleum migration: Am. Assoc. Petroleum Geologists Bull., v. 53, no. 1, p. 73-93.

Echols, D. J ., and Malkin, D. S., 1948, Wilcox (Eocene) stratigraphy, a key to production: Am. Assoc. Petroleum Geologists Bull., v. 32, no. $1, p .11-33$.

Fisher, W. L., 1969a, Facies characterization of Gulf Coast Basin delta systems, with some Holocene analogues: Gulf Coast Assoc. Geol. Soc. Trans., v. 19, p. 239-261. 
1969b, Gulf Coast Basin Tertiary Delta systems: in Delta Systems in the exploration for oil and gas, a research colloquium, Bur. Econ. Geology, Texas Univ., Austin, p. 30-39. 1971, Ancient delta systems of the Gulf of Mexico basin: Houston Geol. Soc. Bull, v. 13, no. 7, p. 3-4.

Fisher, W. L., and McGowen, J. H., 1967, Depositional systems in the Wilcox Group of Texas and their relationship to occurrence of oll and gas: Gulf Coast Assoc. Geol. Soc. Trans., v. 17, p. 105-125.

1969, Depositional systems in Wilcox Group (Eocene) of Texas and their relation to occurrence of oil and gas: Am. Assoc. Petroleum Geologists Bull., v. 53, no. 1, p. 30-54.

Fisk, H. N., 1944, Geological investigation of the alluvial valley of the lower Mississippi River: U.S. Dept. Army, Mississippi River Comm., $78 \mathrm{p}$.

1960, Recent Mississippi River sedimentation and peat accumulation: 4th Internat. Cong. Carboniferous Stratigraphy and Geology (Heerlen, 1958) ,Comp. Rend. , p. 187-199.

Fisk, H. N., and McFarlan, E., Jr., 1955, Late Quaternary deltaic deposits of the Mississippi River: Geol. Soc. America Spec. Paper 62, p. 279-302.

Fowler, Phillip, 1956, Faults and folds of south-central Texas: Gulf Coast Assoc. Geol. Soc. Trans., v. VI, p. 37-42.

Halbouty, M. T., 1967, Salt domes, Gulf region, United States and Mexico: Houston, Tex., Gulf Publishing Co. , $425 \mathrm{p}$.

Hanshaw, B. B., 1964, Cation-exchange constants for clays from electrochemical measurements: in Clays and clay minerals, v. 11, New York, Pergamon Press, p. 397-421. 
Hardin, G. C., 1962, Notes on Cenozoic sedimentation in the Gulf Coast geosyncline, U.S.A., in Geology of the Gulf Coast and Central Texas: Houston Geol. Soc. Guidebook, p. 1-15.

Hendy, W. J., 1957, Lower Cretaceous (Edwards) oil fields, Caldwell and Guadalupe Counties, Texas: Gulf Coast Assoc. Geol. Soc. Trans., v. VII, p. 23-34.

Hjulstrom, Filip, 1939, Transportation of detritus by moving water, in Recent marine sediments: Am. Assoc. Petroleum Geologists Symposium, p. 5-31.

Hoyt, W. V., 1959, Erosional channel in the middle Wilcox near Yoakum, Lavaca County, Texas: Gulf Coast Assoc. Geol. Soc. Trans., v. IX, p. 41-50.

Jones, P. H. , 1969a, Hydrology of Neogene deposits in the northern Gulf of Mexico basin: La. Water Resources Research Inst. Bull. GT-2, Louisiana State Univ., Baton Rouge, La., 105 p.

1969b, Hydrodynamics of geopressure in the northern Gulf of Mexico basin: Jour. Petroleum Technology, v. 21, p. 803-810. 1970, Geothermal resources of the northern Gulf of Mexico basin, in Geothermics: Pisa, Italy, Spec. Issue 2, v. 2, pt. 1, p. 14-26.

Jones, P. H., and Buford, T. B., 1951, Electric logging applied to groundwater exploration, in Geophysics: v. 16, no. 1, p. 115-139.

King, P. B., 1959, The evolution of North America: Princeton, N. J.. Princeton Univ. Press., 189 p.

Krueger, W. C., Jr., 1968, Depositional environments of sandstones as interpreted from electrical measurements--an introduction: Gulf Coast Assoc. Geol. Soc. Trans., v. 18, p. 226-241. 
Krumbein, W. C., 1948, Lithofacies maps and regional sedimentary-stratigraphic analysis: Am. Assoc. Petroleum Geologists Bull., v. 32 no. 10, p. 1909-1923.

Krumbein, W. C., Sloss, L. L., and Dapples, E. C., 1949, Sedimentary tectonics and sedimentary environments: Am. Assoc. Petroleum Geologists Bull., v. 33, no. 11, p. 1859-1891.

LeBlanc, R. J., 1972, Geometry of sandstone reservoir bodies, in Undergroud waste management and environmental implications: Am. Assoc. Petroleum Geologists Mem. 18, p. 133-190.

LeBlanc, R. J., and Bernard, H. A., 1954, Resume of late recent geological history of the Gulf Coast: Geologie en Mijnbouw, new ser., v. 16c, p. $185-194$.

Lehner, Peter, 1969, Salt tectonics and Pleistocene stratigraphy on Continental Slope of northern Gulf of Mexico: Am. Assoc. Petroleum Geologists Bull., v. 53, no. 12, p. 2431-2479.

Lowman, S. W., 1949, Sedimentary facies in Gulf Coast: Am. Assoc. Petroleum Geologists Bull., v. 33, no. 12, p. 1939-1997.

McKelvey, J. G., Splegler, K. S., and Wyllie, M. R. J., 1959, Ultrafiltration of salt solutions through ion-exchange membranes: Chem. Eng. Prog. Symposium, ser. 25, v. 44, p. 199-208.

Milne, I. H., and Earley, J. W., 1958, Effect of source and environment on clay minerals: Am. Assoc. Petroleum Geologists Bull., v. 42, no. 2, p. 328-338.

Morgan, J. P., 1970, Deltalc sedimentation, modern and ancient: ed. J. P. Morgan, Soc. Econ. Paleontologists and Mineralogists Spec. Pub. 15, 312 p. 
Murray, G. E., 1961, Geology of the Atlantic and Gulf coastal province of North America: New York, Harper and Brothers, $692 \mathrm{p}$.

OCamb, R. D., 1961, Growth faults of south Louisiana: Gulf Coast Assoc. Geol. Soc. Trans., v. XI, p. 139-175.

Pettijohn, F. J., 1949, Sedimentary rocks: New York, Harper and Brothers, $718 \mathrm{p}$.

Powers, M. C., 1967, Fluid release mechanisms in compacting marine mudrocks and their importance in oil exploration: Am. Assoc. Petroleum Geologists Bull., no. 7, v. 51, p. 1240-1253.

Russell, R. J., 1940, Quaternary history of Louisiana: Geol. Soc. America Bull., v. 51, no. 8, p. 1199-1233.

Sellards, E. H., and others, 1935, Structural and economic geology, in The geology of Texas, volume 2, structure: Texas Univ. Bull. 3401, $884 \mathrm{p}$.

Storm, L. W., 1945, Resume of facts and opinions on sedimentation in Gulf Coast region of Texas and Louisiana: Am. Assoc. Petroleum Geologists Bull., v. 29, no. 9, p. 1304-1335.

Stuart, C. A., 1970, Geopressures: Proc. Second Symposium on Abnormal Subsurface Pressure, Jan. 1970, Baton Rouge, La., 121 p.

Tucker, D. R., 1962, Central Texas Lower Cretaceous stratigraphy: Gulf Coast Assoc. Geol. Soc. Trans., v. XII, p. 89-96.

1967, Faults of south and central Texas: Gulf Coast Assoc. Geol. Soc. Trans., v. XVII, p. 144-147.

Weeks, A. W., 1945, Balcones, Luling, and Mexia Fault Zones in Texas: Am. Assoc. Petroleum Geologists Bull., v. 29, no. 12, p. 1733-1737. 
Weller, J. M., 1959, Compaction of sediments: Am. Assoc. Petroleum Geologists Bull., v. 43, no. 2, p. 273-310.

Wilhelm, Oscar, and Ewing, Maurice, 1972, Geology and history of the Gulf of Mexico: Geol. Soc. America Bull., v. 83, p. 575-600. 